\title{
Role of sea ice in global biogeochemical cycles: Emerging views and challenges
}

\author{
Martin Vancoppenolle ${ }^{1}$, Klaus M. Meiners ${ }^{2,3}$, Christine Michel ${ }^{4}$, Laurent Bopp ${ }^{5,1}$, Frédéric \\ Brabant $^{6}$, Gauthier Carnat ${ }^{6}$, Bruno Delille ${ }^{7}$, Delphine Lannuzel ${ }^{3}$, Gurvan Madec ${ }^{1}$, Sébastien \\ Moreau $^{8}$, Jean-Louis Tison ${ }^{6}$, Pier van der Merwe ${ }^{3}$. \\ ${ }^{1}$ Laboratoire d'Océanographie et du Climat, CNRS, Paris, France. \\ ${ }^{2}$ Australian Antarctic Division, Department of Sustainability, Environment, Water, Population and Communities, \\ Kingston, Tasmania, Australia. \\ ${ }^{3}$ Antarctic Climate and Ecosystems Cooperative Research Centre, University of Tasmania, Hobart, Australia. \\ ${ }^{4}$ Fisheries and Oceans Canada, Winnipeg, Canada. \\ ${ }^{5}$ Laboratoire des Sciences du Climat et de l'Environnement, CNRS, Gif-sur-Yvette, France. \\ ${ }^{6}$ Laboratoire de Glaciologie, Université Libre de Bruxelles, Belgium. \\ ${ }^{7}$ Unité d'Océanographie Chimique, Université de Liège, Belgium. \\ ${ }^{8}$ Georges Lemaître Centre for Earth and Climate Research, Earth and Life Institute, Université catholique de \\ Louvain, Louvain-la-Neuve, Belgium.
}

Manuscript revised for Quaternary Science Reviews (Version 2.0, Feb 12, 2013). Special Issue: Sea ice in the Paleoclimate System: Modelling Challenges and Status of Proxies (Editors: de Vernal, Gersonde, Goosse, Seidenkrantz, Wolff).

Contact author information

Martin Vancoppenolle

Laboratoire d'Océanographie et du Climat (Expérimentations et Approches Numériques). LOCEAN - UMR7159 CNRS / IRD /

UPMC / MNHN

IPSL Boîte 100; 4, Place Jussieu

75252 Paris Cedex 05 France

e-mail: martin.vancoppenolle@locean-ipsl.upmc.fr

tel : +33 (0)1.44.27.35.80 fax : +33 (0)1.44.27.38.05

\section{Contents}

1. Introduction

2. Physical controls on sea ice biogeochemistry

2.1 Large scale sea ice characteristics

2.2 Sea ice mass balance

2.3 Factors influencing light availability in sea ice

2.4 Controls of fluid transport on biogeochemical tracers

3. Biogeochemical processes

3.1 Organic carbon processes in sea ice

3.2 Macro-nutrients in sea ice and in the water column

3.3 Trace metals

3.4 Biological interactions with the water column

3.6 Inorganic carbon dynamics

3.7 Other climatically significant gases: DMS, $\mathrm{NO}$ and $\mathrm{CH}_{\text {. }}$

3.8 Sea ice surface, bromine and tropospheric ozone chemistry

4. Modelling and up-scaling the role of sea ice in the marine biogeochemical cycles

5. Discussion and outlook

References

Tables and Figures 


\section{Abstract}

Observations from the last decade suggest an important role of sea ice in the global biogeochemical cycles, promoted by (i) active biological and chemical processes within the sea ice; (ii) fluid and gas exchanges at the sea ice interface through an often permeable sea ice cover; and (iii) tight physical, biological and chemical interactions between the sea ice, the ocean and the atmosphere. Photosynthetic micro-organisms in sea ice thrive in liquid brine inclusions encased in a pure ice matrix, where they find suitable light and nutrient levels. They extend the production season, provide a winter and early spring food source, and contribute to organic carbon export to depth. Under-ice and ice edge phytoplankton blooms occur when ice retreats, favoured by increasing light, stratification, and by the release of material into the water column. In particular, the release of iron - highly concentrated in sea ice - could have large effects in the iron-limited Southern Ocean. The export of inorganic carbon transport by brine sinking below the mixed layer, calcium carbonate precipitation in sea ice, as well as active iceatmosphere carbon dioxide $\left(\mathrm{CO}_{2}\right)$ fluxes, could play a central role in the marine carbon cycle. Sea ice processes could also significantly contribute to the sulphur cycle through the large production by ice algae of dimethylsulfoniopropionate (DMSP), the precursor of sulfate aerosols, which as cloud condensation nuclei have a potential cooling effect on the planet. Finally, the sea ice zone supports significant ocean-atmosphere methane $\left(\mathrm{CH}_{4}\right)$ fluxes, while saline ice surfaces activate springtime atmospheric bromine chemistry, setting ground for tropospheric ozone depletion events observed near both poles. All these mechanisms are generally known, but neither precisely understood nor quantified at large scales. As polar regions are rapidly changing, understanding the large-scale polar marine biogeochemical processes and their future evolution is of high priority. Earth system models should in this context prove essential, but they currently represent sea ice as biologically and chemically inert. Paleoclimatic proxies are also relevant, in particular the sea ice proxies, inferring past sea ice conditions from glacial and marine sediment core records and providing analogs for future changes. Being highly constrained by marine biogeochemistry, sea ice proxies would not only contribute to but also benefit from a better understanding of polar marine biogeochemical cycles. 


\section{Introduction}

Past and on-going climatic changes are amplified in the polar regions [Holland and Bitz, 2003]. Current climate changes, associated with largescale anthropogenic emissions of greenhouse gases, involve a warming of the ocean, changes in its chemical composition, as well as a dramatic sea ice retreat in the Arctic [Comiso et al., 2010]. Future changes in the polar seas and continued sea ice retreat [Arzel et al., 2006] will affect future marine biogeochemistry, with important feedbacks on climate and consequences for marine ecosystems, some of which have already been observed [e.g., Montes-Hugo et al., 2009; Wassmann et al., 2011]. Paleo-climate studies indicate that past climatic and atmospheric composition changes were associated with extensive modifications in the polar oceans, in terms of circulation, sea ice cover and chemical composition [Crosta et al., 1998; Sarnthein et al., 2003; de Vernal et al., 2005; Sigman et al., 2010]. While a seasonal ice cover should subsist in the future [Armour et al., 2011], the future large-scale biogeochemical dynamics of the polar oceans and in particular the contribution of sea ice are difficult to predict.

Ocean biogeochemistry exerts a large control on atmospheric chemistry and climate: by absorbing about a fourth of anthropogenic carbon dioxide $\left(\mathrm{CO}_{2}\right)$ emissions [Sabine et al., 2004], the ocean dampens global warming. The polar and sub-polar oceans are of central importance as they support most of the oceanic $\mathrm{CO}_{2}$ uptake [Takahashi et al., 2009]. Air-sea carbon exchanges are ultimately driven by two main categories of processes: the solubility and biological pumps. The solubility pump is the ensemble of physical and chemical processes driving $\mathrm{CO}_{2}$ dissolution and outgassing. The biological pump is driven by (i) the fixation of inorganic carbon into organic matter and its export to depth by sinking plankton material and (ii) the formation of calcium carbonate $\left(\mathrm{CaCO}_{3}\right)$ via calcification, releasing $\mathrm{CO}_{2}$ [Sigman et al., 2010]. While the natural carbon cycle is largely driven by the biological pump [Sarmiento and Gruber, 2006], the uptake of anthropogenic carbon can be, so far, almost entirely explained by physical and chemical processes [Prentice et al., 2001]. The oceanic $\mathrm{CO}_{2}$ absorption capacity decreases with increasing oceanic $\mathrm{CO}_{2}$ burden, but may also be reduced because of future anthropogenic climate change (decreasing solubility and increased upper ocean stratification), hence amplifying global warming [Friedlingstein et al., 2006]. The ocean suffers from the increase in its $\mathrm{CO}_{2}$ burden: more dissolved $\mathrm{CO}_{2}$ acidifies the ocean [Doney et al., 2009], threatening sensitive and essential marine species, with potential consequences for entire marine food webs. Besides absorbing $\mathrm{CO}_{2}$, the ocean is also a preferential site for dimethylsulfide (DMS) emissions. In the atmosphere, DMS acts as a precursor of acidic aerosol sulfates which as cloud condensation nuclei have a potential cooling effect on the planet [Charlson et al., 1987; Watson and Liss, 1998].

Sea ice - the ice forming from the freezing of seawater [WMO, 1970] - is one of the largest known biomes on Earth [Dieckmann and Hellmer, 2010], covering about $7 \%$ of the World Ocean, with remarkable seasonal variations seen in both hemispheres [see Comiso, 2010, for a review]. The Arctic sea ice pack has lost about $30 \%$ of its summer coverage over the last thirty years [e.g., Comiso, 2010] with a spectacular culmination in 2012. This could lead to a summer ice-free Arctic Ocean by the middle of this century [e.g., Massonnet et al., 2012]. The Antarctic sea ice extent has slightly increased over the last thirty years $(\sim 1 \%$ per decade). However, regional variability is large: increases in the Ross and Weddell Sectors exceed the strong retreat in the Amundsen-Bellingshausen regions [Stammerjohn et al., 2012]. In addition, the Antarctic sea ice extent is consistently projected to significantly decrease by the end of this century [Arzel et al., 2006]. The implications of sea ice retreat on the future oceanic capacity to absorb $\mathrm{CO}_{2}$ and emit DMS, as well as the consequences for climate change, ocean acidification and marine ecosystems, are poorly understood.

Focussing on sea ice processes relevant to polar marine biogeochemistry (see Figure 1) is first motivated by the potentially significant influence of sea ice on air-sea gas exchanges. Seen as an impervious cap, sea ice would drastically reduce air-sea $\mathrm{CO}_{2}$ exchange [Stephens and Keeling, 2000]. However this is hardly the case in practice, because of the 
presence of open water within the pack (leads and polynyas), providing pathways for atmosphere-ocean gas exchanges [Morales Maqueda and Rahmstorf, 2002]. Sea ice itself is permeable when warm enough [e.g., Golden et al., 1998], supporting gas exchanges [e.g., Delille et al., 2007; Nomura et al., 2010; Papakyriakou and Miller, 2011] and acts as a source for some gases, for example DMS [Zemmelink et al., 2008] and potentially Bromine Oxide (BrO) [e.g., Simpson et al., 2007]. Until now, the research community has mainly been interested in the study of biogenic and climatically significant gases (i.e., $\mathrm{N}_{2} \mathrm{O}, \mathrm{O}_{2}, \mathrm{CO}_{2}$, DMS) [e.g., Delille et al., 2007], although there is growing interest in research on other gases such as $\mathrm{Br}$ components, which influence polar atmospheric chemistry [e.g., Simpson et al., 2007] and methane $\left(\mathrm{CH}_{4}\right)$, a strong greenhouse gas that is present in gas bubbles released from anoxic sediments to the water column and sea ice [Shakhova et al., 2009]. A second process of interest is the sinking to depth of $\mathbf{C O}_{2}$-rich brine (e.g., richer than seawater), released into the surface ocean during sea ice formation [Rysgaard et al., 2007]. This process should be among the important mechanisms contributing to the ocean $\mathrm{CO}_{2}$ sink, not only today [Rysgaard et al., 2011], but also during the last glacial maximum [Bouttes et al., 2010].

In addition, mounting field observations show dynamic biogeochemical processes in the sea ice zone [Thomas and Dieckmann, 2010], with potential impacts on open ocean biogeochemistry and atmospheric composition. Sea ice microbial communities are present, and often thrive, in a network of liquid saline brine inclusions distributed within a pure ice matrix (see Figure 2), providing a habitat that is both stable and ventilated by nutrient-rich seawater, depending on the complex brine flow through the ice [e.g., Vancoppenolle et al., 2010]. Organic carbon is produced by ice algae via photosynthesis in specific light, nutrient and temperature conditions, to which the organisms are usually adapted and acclimated. Ice algae can also produce copious amounts of dimethylsulfoniopropionate (DMSP), the precursor of DMS, an osmotic regulator and a cryoprotectant [e.g., Tison et al., 2010]. Finally, iron concentrations in sea ice can be much higher than in the ocean and sea ice can act as a seasonal reservoir in the Southern Ocean [Lannuzel et al., 2007; 2011]: growing sea ice incorporates large amounts of iron, later released into surface waters when the ice melts. This seasonal process may temporarily relieve iron limitation on phytoplankton growth, notably in the Southern Ocean [Lancelot et al., 2009], a key player in the marine carbon cycle [Sarmiento and Gruber, 2006; Sigman et al., 2010], but also in the Bering Sea [Aguilar-Islas et al., 2008]

Sea ice proxies integrate information from biological, chemical and physical processes occurring in the polar oceans in an attempt to reconstruct past sea ice conditions [see Armand and Leventer, 2010, for a review]. Many sea ice proxies rely on assumptions related to the biogeochemical properties of the polar oceans, as recorded in marine sediment or glacial ice cores. For instance, changes in diatoms and dinoflagellates community composition, attributed to the open ocean-sea ice zone transition, are used to reconstruct past sea ice characteristics. Crosta et al. [2008], de Vernal et al. [2005] and Müller et al [2009], based on marine sediment core data, use diatom frustules, dynocysts and biomarkers specifically produced by sea ice-associated diatoms and open water phytoplankton, respectively. Curran et al. [2003] and Wolff et al. [2006] use the concentration of methane-sulphonic acid (MSA), an atmospheric by-product of DMS emission in the sea ice zone; and sea salt sodium from glacial ice core data, respectively. However, Hezel et al. [2011] - in an attempt to model the sulphur cycle in the Southern Ocean - find that the presence of sea ice does not exert the dominant control on the interannual variability in DMS emissions. This, combined with the longer simulated lifetime of MSA and DMS in the atmosphere in the high latitudes, raises questions about the applicability of MSA as a proxy for the global Antarctic sea ice extent. Hence, it is apparent that reliable estimates of past sea ice coverage require a proper understanding of present-day large-scale biogeochemical processes occurring in the polar oceans. Conversely, reconstructions of past sea ice extent could enhance our understanding of past polar marine biogeochemistry and reduce uncertainty in future projections of the physical, biological and chemical characteristics of the global ocean. 
In this paper, our goal is (i) to review recent advances and caveats in the observation and modelling of the processes driving the dynamics of chemical elements and biological material in the sea ice zone that are relevant to large-scale polar biogeochemical cycles, (ii) to examine the challenges that we face to upscale those processes and understand their role in the global marine biogeochemical cycles, and (iii) to discuss how the growing fields of sea ice biogeochemistry and sea ice paleo-proxy development could synergistically evolve and contribute to each other. We first revisit the physical forcings of relevance to large-scale sea ice biogeochemical processes (Section 2). In Section 3, we summarize recent information on some of the key sea ice biogeochemical properties and processes, with particular focus on their potential large-scale impact and on the associated uncertainties. In Section 4, we review the modelling approaches that have been used to represent polar marine biogeochemical processes. Finally, in Section 5, we give directions for future research with respect to sea ice proxies.

\section{Physical controls on sea ice biogeochemistry}

An analysis of sea ice vertical profiles of the most relevant biogeochemical tracers reveals contrasting behaviours (Figure 3). Inorganic macro-nutrients generally conservatively follow salinity, with concentrations much smaller than seawater values in bulk ice. Significant deviations in nutrient concentrations as compared to salinity are associated with biological activity. Gases such as argon ( $\mathrm{Ar}$ ) and oxygen $\left(\mathrm{O}_{2}\right)$ have relatively higher and more variable concentrations, compared to ice salinity, because of the formation of gas bubbles. However their concentrations are still below seawater values, except sometimes near the surface. Organic matter and dissolved iron typically show higher concentrations in sea ice than in the underlying ocean. The vertical profiles of biogeochemical sea ice properties reveal the disparity in the physical and biogeochemical processes driving them, which we review hereafter.

Physical processes provide the first set of constraints for biogeochemical developments in sea ice as envisioned by Ackley and Sullivan [1994]. In this section, we cover the aspects of sea ice physics that we consider relevant for biogeochemistry, in both hemispheres.

\subsection{Large scale sea ice characteristics}

Some differences in the characteristics of the polar oceans ice covers (see Table 1 for a summary) are driven by the strong differences in their regional geographic, geo-morphological and geophysical settings [e.g., Eisenman, 2009]. The Arctic Ocean is a high latitude $\left(>65^{\circ} \mathrm{N}\right)$ semienclosed basin with only limited connection and exchange with the world's oceans. It is characterized by extensive continental shelves, serving as important areas for sea ice formation and for primary productivity. In contrast, the Southern Ocean is circumpolar, connecting the Atlantic, Indian and Pacific Oceans and showing an ice cover ranging over $55-75^{\circ} \mathrm{S}$, i.e., at lower latitudes when compared to the Arctic. The Antarctic continental shelf area is relatively narrow, and extensive areas of sea ice formation are located over deep waters [Dieckmann and Hellmer, 2010].

Ice extent, monitored from satellites continuously since 1979 , varies seasonally more substantially in the Antarctic than in the Arctic. Arctic first-year sea ice cover only makes about half of the total ice extent, while in Antarctica first-year sea ice largely dominates. Over 1979-2009, the annual mean Arctic sea ice extent has been rapidly decreasing by almost $4 \%$ per decade, while in the Southern Hemisphere, ice extent has slightly increased by about $1 \%$ per decade [Comiso, 2010]. Regional scatter in the trends is significant in both hemispheres. In particular, the Southern Hemisphere increase has to be viewed in regard to strong inter-regional differences: the sharp decrease in the Amundsen/Bellingshausen sector is slightly more than compensated by increases in the Ross, Weddell and Indian sectors [Stammerjohn et al., 2012]. Changes in the timing of sea ice retreat and freeze-up have significant and regionally dependent impacts on primary production [Arrigo et al., 2008b; Montes-Hugo et al., 2009; Stammerjohn et al. 2008] and associated marine food webs [Grebmeier et al., 2006; Moreau et al., 2010].

As sea ice is much thinner than it is wide, vertical exchange of biogeochemical material is of primary importance. Ice thickness, however, is more difficult to observe from space than ice extent, and hence global ice thickness data are 
relatively scarce. In the Arctic, combined information from upward-looking sonars onboard submarines as well as satellite laser altimeters suggests a decrease in ice thickness from $3.64 \mathrm{~m}$ in 1980 to $1.85 \mathrm{~m}$ in 2008 in the Arctic Ocean [Kwok and Rothrock, 2009]. In the Southern Hemisphere, the most reliable source of information for ice thickness, the ASPeCt (Antarctic Sea ice Processes and Climate) database, a compilation of ship-based visual observations, suggests a mean ice thickness of $0.87 \pm 0.91 \mathrm{~m}$ [Worby et al., 2008] over 19812005. Because of sampling limitations, temporal changes cannot be derived from the ASPeCt database, but on-going progress in remote sensing techniques is being made towards that goal. A recent model study including satellite ice concentration assimilation suggests an increasing Antarctic sea ice volume by $5.6 \pm 5.3$ $\%$ per decade over 1980-2008 [Massonnet et al., in revision].

During its formation, sea ice incorporates biogeochemical material (e.g., macro-nutrients, iron, organic matter, sediments), which is stored, transformed, and later released in seawater when the ice melts. In addition, organic matter accumulates in the sea ice as a result of autoand heterotrophic production. Therefore, sea ice drift, induced by winds and ocean currents, horizontally redistributes biogeochemical material. Ice drift is observed using drifting buoys as well as satellites by comparing two subsequent satellite images [Kwok et al., 1990]. Satellite-derived maps of large-scale sea ice drift patterns can be found in Emery et al. [1997]. Ice velocity is on average between 6 and $7 \mathrm{~km} /$ day in the Arctic and has been increasing by $17 \%$ per decade in winter over 1979-2007 [Rampal et al., 2009]. In the Antarctic, ice velocity typically ranges between 8 and $9 \mathrm{~km} /$ day [Heil et al., 2006], while wind patterns over the last two decades have significantly changed [Holland and Kwok, 2012]. The consequences of ice transport include the potential initiation of phytoplankton blooms induced by the storage and release of iron in the iron-limited Southern Ocean marginal ice zones [Lancelot et al., 2009; Lannuzel et al, 2010]. Ice transport also involves that the material found in marine sediment cores used in paleoclimate proxies may reflect the conditions a few hundreds to thousands of kilometres away from where the core was extracted.

\subsection{Sea ice mass balance}

Large-scale variations in sea ice mass are driven by thermodynamic and dynamic processes, which all affect the ice-ocean exchanges of biogeochemical material. Several mechanisms contribute to a net gain of ice mass. (i) Small unconsolidated (frazil) ice crystals forming from super-cooled water either aggregate at the ocean's surface or adhere onto pre-existing ice [Martin, 1981; Smedsrud, 2002]. (ii) An existing ice cover over quiescent waters grows from the base by congelation if the upward conductive heat flux is higher than the oceanic heat input [Maykut and Untersteiner, 1971]. (iii) Snow ice forms by the refreezing of slush at the snow-ice interface. Slush forms from the infiltration of seawater and brine at the base of the snow pack, when snow is deep enough to depress the ice surface below sea level [e.g., Maksym and Markus, 2008]. (iv) Superimposed ice forms if snow melt water, percolating downwards, refreezes deeper in the snow or at the snow-ice interface, where temperature is lower than freezing [e.g., Nicolaus et al., 2009]. The ice formation mechanism can be tracked from specific textural and oxygen isotopes $\left(d^{18} \mathrm{O}\right)$ signatures: granular type for frazil, columnar type for congelation, granular with low $\mathrm{d}^{18} \mathrm{O}$ for snowice formation, and polygonal granular for superimposed ice formation [Weeks and Ackley, 1986; Eicken, 1998; Tison et al., 1998; Haas et al., 2001; Tison et al., 2008]. Depending on the energetic constraints at the interfaces, ice can melt at its surface, at its base, and from the lateral edges of the ice floes.

Changes in the thermodynamic regime of the Arctic sea ice cover have been observed. In the $20^{\text {th }}$ century, the Arctic sea ice mass balance was driven mostly by basal congelation growth and surface melt [Untersteiner, 1961]. In contrast, over the last two decades, the shares of basal and surface melt have been comparable. Thinner ice fosters the summer reduction in ice concentration, which in turn increases basal melt through to the ice-albedo feedback, as observed [Perovich et al., 2003; Perovich et al., 2007] and simulated [Vancoppenolle et al., 2009b]. Because the long-term ice retreat is more pronounced in summer than in winter [see, e.g., Deser and Teng, 2008], the amplitude of the seasonal cycle of Arctic sea ice extent has been increasing, which means that the total annual sea ice growth and 
melt has been increasing and should continue to increase in the future [e.g., Holland et al., 2006]. In the Southern Ocean, observations and models indicate that ice formation mechanisms are more diverse than in the Arctic: congelation, frazil ice and snow-ice formation all contribute significantly [Worby et al., 1996; Jeffries et al., 1997; Vancoppenolle et al., 2009b]. The direct exposure of the Southern Ocean sea ice pack to ocean swell results in a higher contribution of frazil ice than in the Arctic, associated with so-called pancake ice formation [Lange et al., 1989]. Because Antarctic air masses are relatively cold and dry [Andreas and Ackley, 1982], and because the ocean heat flux is much larger than in the Arctic [e.g., McPhee, 2008], basal ice melt largely overcomes surface melt in the Southern Ocean [Vancoppenolle et al., 2009b; Maksym et al., 2012]. Lateral melting is confined to the zones where ice floes are sufficiently small [Steele, 1992; Perovich et al., 2003] and has not been clearly evidenced as a significant large-scale mass balance contributor.

Without dynamical deformation processes, the sea ice would be relatively uniform. However, sea ice dynamics introduce small-scale variations in ice thickness through opening (the creation of leads and polynyas), rafting (the overriding of two ice plates on top of each other) and ridging (the piling of broken ice pieces into pressure ridges) [see Tuhkuri and Lensu, 2002]. Ridging and rafting do not induce a net change in sea ice volume, but change the sea ice landscape and the areal distribution of ice thickness. Pressure ridges and the constant formation of new ice in recently opened water due to exposure to cold air induces high variability in ice thickness at subfloe scales [Thorndike et al., 1975]. In the Arctic, models suggest that slightly less than half of the ice volume lies within pressure ridges, while rafted ice contribution is likely very small [Mårtensson et al., 2012]. In the Antarctic, observations suggest a significant influence of deformation processes on the thickness distribution of Antarctic sea ice [Worby et al., 2008], but a proper quantification of the volumetric contribution of deformed ice has still yet to come. As the meridional change in zonal stress associated with the transition from the Antarctic Circumpolar Current to the coastal East Wind Drift induces a generally divergent circulation in the Antarctic sea ice zone, open water is more prevalent in winter in the Antarctic sea ice pack ( $>20 \%$ of extent) than in the Arctic $(\sim 10 \%)$ [Gloersen et al., 1993].

Sea ice thermodynamic growth and mechanical redistribution provide important controls on sea ice and upper ocean biogeochemistry. Columnar ice growth at the ice base [Notz and Worster, 2009] and snow ice formation associated with surface flooding trap salt [Maksym and Jeffries, 2000; Vancoppenolle et al., 2010], as well as dissolved and particulate material [Krembs et al., 2001; Giannelli et al., 2001] initially present in seawater, promoting the development of bottom and surface ice algal communities. Rising frazil ice crystals are known to harvest some of the available particulate material suspended in the water column and to incorporate it in the ice [Martin, 1981; Garrison et al., 1983; Ackley and Sullivan, 1994]. Due to brine drainage, a large part of dissolved material is quickly released to the ocean (see Section 2.3). Melting sea ice releases material in seawater [Riebesell et al., 1991; Michel et al., 1996], which affects both planktonic and benthic communities.

Ridging and rafting must affect ice algal communities significantly, but to what extent is not well understood. The analysis of a circumpolar Southern Ocean sea ice chlorophyll database suggests that at least a third of the biomass in the Southern Ocean pack ice is associated with internal communities living in deformed ice [Meiners et al., 2012]. Ice deformation by ridging and rafting vertically redistributes biogeochemical material [Horner et al, 1992]. Rafting brings algal communities that were previously near the ice base to the ice interior, while ridging randomly redistributes material within the pressure ridges. Ridges are initially highly porous: about $30 \%$ of ridged ice volume is trapped seawater, which should expose the newly dispersed communities to large amounts of macro-nutrients and therefore make this habitat very productive, but this is still a speculation at this stage. In the Arctic, this would also largely depend on the amount of nutrients initially present in seawater, which is controlled by vertical mixing and upwelling in the underlying ocean. 


\subsection{Factors influencing light availability in sea ice}

The strong seasonality in light conditions in polar regions, from complete winter darkness to 24-h daylight near the poles, sets constraints on quantum irradiance available to primary producers, or Photosynthetically Active Radiation (PAR). The factors influencing radiation transfer through sea ice are mainly the snow cover, melt ponds, as well as the presence of sediments, pollutants and biological material in the ice. The snow cover above sea ice can be very reflective (hence opaque) and is therefore of primary importance in spring. The evolution of snow depth is governed by snowfall, sublimation, melt and metamorphism. In addition, wind redistributes snow from undeformed ice towards the vicinity of rough topographic features such as pressure ridges, while some blowing snow can be lost on its way to open water [Massom et al., 2001; Sturm and Massom, 2010; Leonard and Maksym, 2011]. The irregularities of the sea ice surface, combined with the spatially dependent snowfall rate, snow thermodynamics and wind redistribution induce large variations in snow depth even at sub-meter scales [see, e.g., Mundy et al., 2005; Lewis et al., 2011]. This has important consequences for light-dependent biological process in and under ice, as snow attenuates light very efficiently.

Measurements of radiation extinction coefficients in the visible waveband fall within $6-80 \mathrm{~m}^{-1}$ for all types of snow [Hamre et al, 2004; Järvinen and Lepparanta, 2010], within $0.8-1.5 \mathrm{~m}^{-1}$ for natural sea ice [e.g. Light et al., 2008; Nicolaus et al., 2010], and within $0.02-0.49 \mathrm{~m}^{-1}$ for seawater [e.g., DeGrandpre et al., 1996]. Hence a few centimetres of snow can attenuate as much shortwave radiation as a meter of sea ice. Field studies suggest that, within a floe, ice algae are found where light intensity is the strongest [Rysgaard et al., 2001], with the thickness of the combined snow-ice system being the most important factor controlling the algal biomass patch sizes at subfloe scales $(\sim 10 \mathrm{~m})$ in the absence of nutrient limitation [Gosselin et al., 1986; Rysgaard et al., 2001]. Historical data of Southern Ocean sea ice chlorophyll [Meiners et al., 2012] indicate that low ice algal biomasses (< $1 \mathrm{mg} \mathrm{chla} / \mathrm{m}^{2}$ ) constitute $\sim 30 \%$ of observations, even when sea ice is overall biologically productive, which is in part due to light attenuation by snow. Besides its effect on light attenuation, snow depth also controls the thermal field and hence the intensity and depth of brine convection rates [Notz and Worster, 2008]. Snow depth also determines the formation of snow ice and the flooding of the snow base by seawater, which can bring nutrients near the ice surface and promote the development of surface layer communities [Fritsen et al., 1994].

The Antarctic sea ice pack experiences some of the largest snowfall rates on Earth, hence high snow-loading results in frequent flooding of Antarctic sea ice, fostering snow ice formation [Maksym and Markus, 2008]. In contrast, snowfall on Arctic sea ice is generally lower than in the Antarctic, whereas sea ice is generally thicker, and therefore requires a heavier snow cover to flood. Therefore, surface flooding is rather rare in the Arctic. In the Northern Hemisphere, due to the proximity of pollutant sources, snow falling onto sea ice can result in deposition and accumulation of $\mathrm{NO}_{3}, \mathrm{NH}_{4}$ and soot [Ehn et al., 2004; Nomura et al., 2011].

The incorporation of sediments, rare in Antarctic sea ice but frequently observed in Arctic sea ice especially near the coasts, strongly affects light availability for ice algae and transmittance of light to the under ice pelagic environment [Light et al., 1998; Gradinger et al., 2009]. Sediment-laden ice has been shown to impact on the spectral light composition and can also delay and inhibit the ice algal spring bloom development [Gradinger et al., 2009].

Another property of importance for light availability under sea ice is the presence of melt ponds. These are pools resulting from the accumulation of melt water over impermeable sea ice, forming shortly after melt onset [Perovich et al., 2002b; Polashenski et al., 2012], and characterized by much lower albedo than bare ice [Perovich and Polashenski, 2012]. Widespread in the Arctic, where they cover about 1.5 million $\mathrm{km}^{2}$ at their summer maximum [Rösel and Kaleschke, 2012], melt ponds are rarely reported on Antarctic sea ice, because of drier and colder air than in the Arctic [Andreas and Ackley, 1982], favouring evaporation rather than melt water accumulation at the surface [Nicolaus et al., 2009]. Melt ponds efficiently transmit light to the underlying ocean, with transmission values typically an order of magnitude higher than bare 
ice [Frey et al., 2011]. Therefore, substantial melt pond coverage changes the ocean's surface energy budget [Nicolaus et al., 2012] and stimulates under-ice primary productivity [e.g., Arrigo et al., 2012]. Melt ponds also host their own planktonic communities [Horner et al, 1985], but their contribution in the large-scale carbon cycle is likely limited [Lee et al., 2012].

\subsection{Controls of fluid transport on \\ biogeochemical tracers}

One of the key characteristics of sea ice making it suitable as a microbial habitat is the presence of liquid inclusions of saline brine, which are at least near the ice base connected with the underlying ocean, providing pathways for nutrient supply [Reeburgh, 1984, Petrich and Eicken, 2010] and gas exchange [Delille et al., 2007; Tison et al., 2010; Loose et al., 2011]. The salt trapped within sea ice during formation is hardly incorporated into the ice crystalline lattice [Weeks and Ackley, 1986] and rather remains dissolved in brine [see Hunke et al., 2011, for a review]. The bulk salinity of sea ice (i.e., for the combined ice and brine pockets) is usually much less than seawater, although brine salinity can be much higher. Brine salinity strongly increases with decreasing temperatures to maintain phase equilibrium within sea ice, while the brine volume fraction increases with temperature and ice bulk salinity [Assur, 1958; Cox and Weeks, 1983; Hunke et al., 2011]. As sea ice ages, much of the brine is lost from the ice, decreasing bulk salinity and brine volume.

Above a $\sim 5 \%$ threshold in brine volume, the brine network connects and fluid permeability of sea ice drastically increases [Golden et al., 1998], enabling fluid transport through sea ice. In practice, the vertical structure of fluid permeability in sea ice is seasonally dependent, following temperature changes modulating the vertical position of the $5 \%$ brine volume contour. Near the ice base, where the ice is warm and saline, the brine network is virtually always in connection with the underlying ocean. In winter, the $5 \%$ brine volume contour is at about one third of the ice thickness from the ice-ocean interface, hence only the lowermost part of the ice is permeable [Vancoppenolle et al., 2007; Notz et al., 2009]. In summer the $5 \%$ brine volume contour moves upwards in the ice due to warming. Full-depth connectivity happens in spring once the ice is warm enough [Jardon et al., 2013]. In summer, in particular in the Arctic, strong desalination of sea ice due to flushing can reduce the brine volume below $5 \%$ over most of the sea ice depth [Vancoppenolle et al., 2007].

Recent results suggest life in sea ice also exerts some control on brine inclusions. Exopolymeric polysaccharides (EPS) released by ice algae and bacteria [Krembs et al., 2002a] change the size and shape of brine inclusions, reduce fluid permeability and increase salt retention in sea ice [Krembs et al., 2011]. To which extent ice algae affect fluid transport through sea ice in natural conditions is not clear yet and not represented in current thermodynamical theories of the sea ice microstructure.

The markers of biochemical activity - nutrients, gases, micro-organisms - are all influenced by the sea ice microstructure. In practice, they are considered as passive tracers, i.e., influenced by their physical environment but not affecting the sea ice thermodynamic state. Their abundance in the ice can be characterized using bulk molar volumetric concentration $C(z, t)$, i.e., the number of moles of tracer per unit volume of sea ice. This volume has to be small enough so that a single brine volume fraction is representative of the volume, but large enough so that individual brine inclusions are averaged [Jeffery et al., 2011]. Changes in $C$ are driven by physical transport $\left(S^{\Phi}\right)$ and by biological and chemical source and sinks $\left(S^{\beta}\right)$ :

$$
\frac{\partial C}{\partial t}=S^{\phi}+S^{\beta \chi}
$$

Physical transport depends on the tracer of interest, which can be of three different kinds: dissolved, gas, or particulate.

\section{Dissolved tracers.}

Dissolved tracers (as dissolved macro-nutrients and inorganic carbon) behave like salt, i.e., their concentration in pure ice is nil and they are transported vertically with brine motion. For these tracers, the brine concentration $C^{b r}$, or the number of moles of tracer per unit volume of liquid brine, is introduced as:

$$
C=e C^{b r},
$$


where $e$ is brine volume fraction. In the sense that sea ice is a two-phase, reactive porous medium, it constitutes a mushy-layer [Notz and Worster, 2009]. Mushy-layer theory provides a theoretical framework to express changes in $C$ due to brine transport (see below), which are currently formulated as functions of $e$ and $C^{\text {br }}$ [see, e.g., Vancoppenolle et al., 2010; Jeffery et al., 2011].

Brine transport. Fluid transport in brine inclusions drives a net loss of salt from the sea ice to the ocean. Fluid transport through the ice is controlled by the vertical thermo-haline structure of sea ice, which determines both the vertical stability of the brine network and its connectivity. Only gravity drainage and flushing are believed to contribute to any measurable net loss of salt [Untersteiner, 1968; Notz and Worster, 2009]. Gravity drainage refers to the natural convection of salty, heavy brine and its replacement with less dense underlying seawater, which is limited to where the ice is permeable and when the brine salinity decreases from the top of the ice downward (when air temperature is below seawater freezing point). This salinity gradient leads to an unstable density gradient of the interstitial brine, prone to convection, primarily through vertical brine channels - liquid conduits extending through the ice which naturally form during sea ice formation [Niedrauer and Martin, 1979; Wells et al., 2011]. Gravity drainage results in an important net rejection of salt from the sea ice into the ocean.

Flushing is the dominant desalination process during the Arctic summer. This process refers to the "washing out" of salty brine by relatively fresh surface melt water that percolates into the pore space during summer [Untersteiner, 1968]. Because surface melting is not frequent in the Antarctic, flushing is rarely observed there [see Vancoppenolle et al., 2009a and references therein]. Flushing also expels dissolved material from the ice during the melt period, which typically ends the ice algal season in the Arctic [e.g., Riedel et al., 2008].

A last brine motion mechanism that potentially can play a role is forced convection. Forced convection in the lowermost parts of the brine network is driven by the pressure difference induced by the shear of ocean current under sea ice, as suggested by theoretical and experimental studies [Neufeld, 2008]. Forced convection may bring in and redistribute salt and nutrients in sea ice, but when, how and how much have not yet been evaluated. Forced convection could occur for instance due to strong tidal currents and play an important role when the brine network is stable in summer. This is corroborated by the hypothesized control of tidal forcing on nutrient supply to the sea ice, required to explain the high ice algal biomass accumulation observed in the bottom layers of fast ice in Resolute Bay, in the Canadian Arctic Archipelago [Cota et al., 1987; Cota and Horne, 1989]. Significant progress on the fundamental understanding of brine transport mechanisms is still required [see, Hunke et al., 2011].

Brine transport and nutrients. Most macronutrients are, like salt, dissolved in brine. Hence, fluid transport removes nutrients from (or supplies them to) the ice interior [Reeburgh, 1984; Vancoppenolle et al., 2010]. Salt is trapped within sea ice during basal accretion and surface flooding. During basal ice growth, the salinity field is continuous across the ice-ocean interface, hence there is no immediate segregation of salt from the ice to the ocean [Weeks and Ackley, 1986] at the advancing front [Notz and Worster, 2009]. All nutrients included in the freezing seawater should conservatively follow salt and be incorporated into forming ice. Flooding of the base of the snow layer under negative freeboard conditions occurs either (i) laterally via the infiltration of seawater through fractures associated with open water, deformed ice and thermal cracks, or (ii) vertically via the percolation of brine through brine channels [Maksym and Jeffries, 2000]. Flooding is a source of salt to the ice surface [Eicken et al, 1992] and should bring and redistribute nutrients near the ice surface.

Interactions between transport and biochemical sources and sinks. Nutrient concentrations in sea ice are in part controlled by brine dynamics but also depend on ice algal uptake and remineralization processes due to heterotrophic activity. Because nutrients are nonconservative elements, affected by biological processes acting as nutrient sources or sinks, the effect of gravity drainage on nutrients can deviate from its effect on salt. Depending on whether the concentration of nutrients in brines is higher or lower than in seawater below, gravity drainage 
rejects or supplies nutrients to the sea ice [Vancoppenolle et al., 2010]. In theory, as long as the air temperature is below the seawater freezing point, which implies an unstable brine salinity profile (i.e., brine salinity increases upwards), gravity drainage can supply nutrients if depleted - to the permeable sections of the ice, which are in most cases restricted to the lowermost $10 \mathrm{~cm}$ of the ice, but can extend further up within the ice in late spring [see, e.g., Zhou et al., in revision].

\section{Gas tracers}

Like salt and nutrients, dissolved gases are incorporated in sea ice and concentrated into brine inclusions during ice formation (basal congelation, snow-ice, frazil) [Matsuo and Miyake, 1966; Glud et al., 2002; Tison et al., 2002], while gas bubbles coming from the ocean below penetrate the ice via the open brine network [Tsurikov, 1979]. Most of the gases are then quickly released into the underlying ocean through convective brine release, where they partly sink, following dense waters convection [Killawee et al., 1998; Rysgaard et al., 2007; Sejr et al., 2011] or escape upwards through the open water-atmosphere interface [Nomura et al., 2006; Loose et al., 2011].

Gas tracers easily form bubbles within growing sea ice, because of two synergetic effects of decreasing ice temperature: (i) brine volume decreases, which increases dissolved gas concentration in brine possibly above gas solubility [Zhou et al., in revision]; and (ii) gas solubility decreases. The latter effect is because brine salinity and temperature are coupled: the increase in solubility due to cooling is overcompensated by the decrease due to increasing brine salinity [Thomas et al., 2010]. Above saturation, if the sum of all dissolved gases partial pressures is higher than the local hydrostatic pressure, bubbles can nucleate and accumulate in the direct vicinity of sea ice inclusions [Tison et al., 2002; Light et al., 2003]. Internal melting also promotes gas bubble formation: melting involves a $\sim 10 \%$ volume reduction, leaving a void where gas will flow from nearby brine until equilibrium [Perovich and Gow, 1996]. When brine inclusions enlarge in spring and summer, the brine concentration of gases decreases, possibly reaching under-saturation.
This under-saturation can be relieved by inputs from dissolving gas bubbles, as well as from atmospheric and oceanic inputs [Tison et al., 2010; Zhou et al., in revision]. If the ice is permeable, gas bubbles can directly escape to the atmosphere. During the melt season, flushing transports dissolved gases towards the ocean.

Gas tracers $\left(\mathrm{O}_{2}, \mathrm{Ar}, \mathrm{CO}_{2}\right)$ are distributed in both the liquid and gas phases, and their bulk concentration is given by:

$$
C=e C^{b r}+C^{b u b}
$$

where $C^{\text {bub }}$ is the contribution of gas bubbles to bulk ice concentration. The physical transport term $\left(S^{\phi}\right)$ in equation (1) includes not only brine transport (affecting $C^{b \eta}$ ), but also gas bubble transport (affecting $C^{\text {bub }}$ ).

While the transport of dissolved gas should be similar to that of salt, the transport of gas bubbles, little studied, is likely driven by different processes, including the buoyant rise of gas bubbles, and their entrapment in the sea ice microstructure [Zhou et al., in revision]. A scaling analysis suggests that gas bubbles should quickly escape out of the ice due to their buoyancy once the brine network opens in spring [Moreau et al., in revision]. Recent observations [Zhou et al., in revision] indicate that the permeability transition for gas bubble transport could occur at a higher brine volume permeability threshold than the commonly accepted threshold of $5 \%$ for fluid transport [Golden et al., 1998].

In contrast to the general behaviour of dissolved salt and nutrients, dissolved gases and gas bubbles can cross the ice-atmosphere interface. Ice-atmosphere gas exchange depends on the differential partial pressure of gases between brine and the atmosphere, wind speed, ice microstructure and snow properties [Delille, 2006; Heinesch et al., 2009; Papakyriakou and Miller, 2011; Bowling and Massman, 2011]. When present, snow can act as an intermediate reservoir for gas until wind speed exceeds a given threshold [Bowling and Massman, 2011; Papakyriakou and Miller, 2011] while, when absent, brine-atmosphere or melt pondatmosphere gas exchanges may occur [Semiletov et al., 2004]. The formation of superimposed ice impedes sea ice-atmosphere 
gas exchanges [Nomura et al., 2010]. The central question of the partitioning of gas exchange between open water and sea ice has not been resolved yet [see, e.g., Loose et al., 2011; and references therein].

Gas dynamics in sea ice are complicated by biogeochemical processes. These include the metabolic activities (i.e., primary production and respiration) [e.g., Arrigo et al., 2010; Deming, 2010], which produce and absorb biogenic gases such as $\mathrm{O}_{2}, \mathrm{CO}_{2}$ and DMS [Gleitz et al., 1995; Glud et al., 2002; Delille et al., 2007; Tison et al., 2010]. They also include carbonate chemistry, which plays an important role in the dynamics of dissolved inorganic carbon (DIC) in sea ice [Delille, 2006; Rysgaard et al., 2007; Miller et al., 2011a; Geilfus et al., 2012], and the precipitation of calcium carbonate $\left(\mathrm{CaCO}_{3}\right)$ in the form of ikaite crystals as recently observed in Arctic and Antarctic sea ice [Dieckmann et al., 2008; 2010].

\section{Particulate tracers}

Particulate tracers cannot dissolve in brine. Their incorporation in the sea ice matrix and actual transport behaviour depends on several characteristics which are not currently well constrained: (i) whether the particles move actively (e.g., flagellates), (ii) whether the particles are transported passively (by moving brine), (iii) whether and how quickly they stick on the walls of brine inclusions or on other impurities, (iv) whether they can get sealed into the sea ice microstructure. For instance, ice microorganisms combine mobility and attachment onto ice surfaces via the release of EPS and icebinding proteins [Krembs et al., 2000; Becquevort et al., 2009; Juhl et al., 2011; Raymond and Kim, 2012].

\section{Biogeochemical processes}

Active biogeochemical processes in sea ice involve macro-nutrients, trace elements, organic carbon, inorganic carbon, other climaticallysignificant gases (DMS, methane, nitrous oxide), and atmospheric halogen chemistry, in strong interaction with oceanic and atmospheric processes.

\subsection{Organic carbon processes in sea ice}

Biodiversity. Sea ice provides a vast habitat for productive microbial communities consisting of algae, bacteria, archea, heterotrophic protists, funghi as well as viruses [Horner et al. 1992; Deming et al., 2010; Thomas and Dieckmann, 2010; Poulin et al., 2011]. Distinct communities are found at the base, in the interior and at the surface of ice floes [see, Horner, 1985; Arrigo et al., 2010]. In terms of biomass, these communities are generally dominated by algae, particularly diatoms during the bloom period. However, heterotrophs can dominate prior to the bloom period, as well as during the winter [Riedel et al. 2008, Niemi et al., 2011; Paterson and Laybourn-Parry, 2012]. There are over one thousand protist species known to live in Arctic sea ice, including diatoms, dinoflagellates, chrysophytes, prasinophytes, silicoflagellates, primnesiophytes and chlorophytes amongst others [Poulin et al., 2011]. Pennate diatoms, with morphotypes resembling surface-associated and benthic life-styles, are the dominant sea ice algal group. The arborescent colonial diatom Nitzschia frigida is the most abundant and the most widely distributed ice algal species in Arctic first-year ice and therefore is a key sea ice species in the circumpolar Arctic [Różańska et al., 2009]. Other diatom species such as Melosira arctica, which can form meter-long strands attached to the sea ice, can also be overwhelmingly dominant in Arctic sea ice. An important Antarctic sea ice pennate diatom genus is Fragilariopsis, which is commonly found in pack ice habitats and has been widely used as a sea ice proxy [see Armand and Leventer, 2010; and references therein]. Ice algae in general extend the duration of the productive season in high latitude ecosystems. This is mostly because ice algae are attached to the ice and therefore not subject to vertical motion in the water column affecting average light exposure of phytoplankton in a mixed layer. Ice algae also provide a critical early season and high-quality food source for the growth and reproduction of pelagic herbivores [Søreide et al., 2010; Flores et al., 2012].

Variability. There is a high spatial and temporal variability in ice algal biomass and production. The seasonal development of ice algal communities is driven by the strong seasonal physical forcing regime of polar marine environments. During the dark winter at high latitudes, protist abundance is relatively low in sea ice [Günther and Dieckmann, 1999; Niemi et al., 2011]; however Arctic winter sea ice biodiversity is comparable to that of spring 
assemblages [Niemi et al., 2011]. Ice algae are typically shade adapted and can thrive at very low irradiances. Increasing light levels in late winter trigger the onset of ice-algal blooms [Lavoie et al., 2005; Meiners et al., 2012]. The decline of Arctic ice algal blooms depends on a variety of factors including nutrient limitation by nitrogen [Różańska et al., 2009] and silicic acid [Lavoie et al., 2005], self-shading [Smith et al., 1988], as well as temperature and brine salinity stress [Arrigo and Sullivan, 1992]. Nutrient limitation occurs when supplies are limited, which is promoted by brine stratification at nearfreezing temperatures. Decreasing light levels, low temperatures and high brine salinities limit ice algal growth during late autumn and winter. For some high-biomass Antarctic sea ice microhabitats, potential algal growth limitation by depleted $\mathrm{CO}_{2}$, elevated brine $\mathrm{pH}$, and oxygen supersaturation has been reported [Gleitz et al., 1995; Thomas et al., 2010]. In contrast, heterotrophic processes, e.g., bacterial activity, heterotrophic grazing and excretion, as well as viral lysis of host cells, can result in nutrient remineralization within the sea ice [Gleitz et al., 1995; Papadimitriou et al., 2007; Riedel et al., 2008; Thomas et al., 2010]. Large spatial variability in ice algal activity is found from submeter to large scales [Rysgaard et al., 2001; Deal et al., 2011], due to processes that operate at micro- (individual pores), meso- (snow distribution) and macro- (nutrient input) scales.

Characterization of biomass and organic carbon. There are several quantities that are used to characterize the organic matter content in sea ice. Chlorophyll a (chl a), the dominant photosynthetic pigment in marine microalgae, is easily measured fluorometrically, and is the most frequently used indicator of autotrophic biomass. Vertically-integrated concentration of $\mathrm{chl}$ a $\left(\mathrm{I}^{\text {chla }}\right)$, or areal chlorophyll content, is an indicator of the total biomass per unit area of sea ice [Gradinger, 2009; Meiners et al., 2012]. $I^{\text {chla }}$ is generally highest in landfast ice, i.e., sea ice that is "fastened" by attachment to the coast, ice shelves, glacier-tongues or locked-in by grounded icebergs. Landfast ice is more productive due to coastal processes that influence nutrient supply, i.e., riverine influence (in the Arctic) and tidal currents, which promote vertical mixing and forced convection in sea ice. Values of $\mathrm{I}^{\text {chla }}$ for a given ice core (or a part of it, depending on authors) range between 1 and 340 $\mathrm{mg} \mathrm{m}^{-2}$ in the Arctic and between $<1$ and 1090 $\mathrm{mg} \mathrm{m}^{-2}$ in the Antarctic, which includes both pack and fast ice [see Arrigo et al. 2010; and references therein]. The highest values probably do not reflect a large-scale measure but rather local maxima. As $\mathrm{I}^{\text {chla }}$ estimates presented in the literature often include only a fraction of the ice thickness, they have to be interpreted carefully.

The sea ice particulate organic matter (POM) pool, operationally defined as material retained on glass-fibre filters with a nominal pore size of 0.7 micron, provides a more general measure of organic matter in sea ice, comprised of different fractions including ice algae, some exopolymers, attached bacteria, heterotrophic protists, and detritus. POM is mostly measured as particulate organic carbon (POC) but particulate organic nitrogen (PON) is also used in nitrogen-based budgets and models.

$\mathrm{POC}$ and $\mathrm{Chl} a$ in sea ice can show strong vertical gradients and can vary spatially and seasonally over 3 orders of magnitude [e.g., Kennedy et al., 2002]. POC and Chl a also vary as a function of the age of sea ice. The distribution of POC in sea ice is usually correlated with that of $\mathrm{Chl} a$, implying that ice algae represent a large part of, and partly produce the POC. However, during fall and winter, sea ice $\mathrm{POC}$ and $\mathrm{Chl} a$ are decoupled, indicating a significant contribution of non-pigmented biomass (heterotrophs and detritus) [e.g., Meiners et al., 2004; Niemi et al., 2011]. In addition, allochtonous riverine and terrestrial material input in sea ice can be high on Arctic shelves, which influences the POM sea ice signature in Arctic sea ice.

While $\mathrm{Chl} a$ is a widely used proxy for ice algal (and phytoplankton) biomass in ecological studies, other cell constituents, such a biogenic silica, a structuring element of diatom frustules, can also be used. Each indicator has advantages and shortcomings. Therefore, a combination of indicators offers the best description of the biomass and physiological state of ice community assemblages. POC indiscriminately measures all of the organic carbon regardless of its physiological (e.g., healthy cells or detritus) or functional (autotrophic or heterotrophic) roles. $\mathrm{Chl}$ a specifically targets phototrophic biomass (excluding cyanobacteria), whereas biogenic silica targets diatoms. Overall, since these 
indicators change with the composition and physiological status of ice communities, they may not accurately reflect ice algal biomass across different seasons, regions and sea ice habitats.

DOM. Dissolved organic matter (DOM) is a diverse pool of molecules including carbohydrates, proteins, amino acids as well as more complex substances such as humic substances. DOM is defined as organic matter smaller than $0.2 \mu \mathrm{m}$. However, operationally, DOM is often measured as the material that passes through glass-fibre filters with a nominal pore size of $0.7 \mu \mathrm{m}$. DOM can be derived from various sources such as viral lysis of cells, inefficient and destructive sloppy-feeding by grazers, with the most important sea ice source being exudation by microalgae. Allochtonous DOM input into marine systems also occurs via rivers transporting complex humic substances into the marine realm. DOM can range in size from monomers to large polymers and can be divided in a biological labile and a relatively stable (refractory) pool. Labile DOM provides an important food source for bacteria channelling energy through sea ice microbial food webs. DOM includes chelating agents that are considered to influence the bio-availability of nutrients, such as iron [Hassler and Schoemann, 2009]. DOC (Dissolved Organic Carbon, measured via catalytic combustion) in the sea ice is often correlated with ice algal biomass and can reach very high concentrations when compared to the pelagic realm. DOC concentrations of up to $>2.5 \times 10^{3} \mu \mathrm{M}$ have been reported for Arctic sea ice [Riedel et al., 2008]. DOC concentrations in Antarctic sea ice vary widely with values of up to $>1.8 \times 10^{3} \mu \mathrm{M}$ in melted ice cores [e.g., Thomas et al., 2001; Herborg et al., 2001; Thomas et al., 2010]. As DOC is further concentrated within sea ice brines, organisms living in brine are exposed to DOC concentrations that are up to 3 orders of magnitude higher than in seawater. Coloured Dissolved Organic Matter (CDOM) constitutes a significant fraction of the sea ice DOM pool and can significantly contribute to the attenuation of sunlight (particularly in the UV wavelength ranges) and serve as substrate for photochemical reactions that can remineralize the CDOM breaking it down into more labile compunds [Belzile et al. 2000; Norman et al., 2011].
EPS. Over the last decade or so, various studies have shown that part of the organic matter is constituted of gel-like organic substances, often referred to as extracellular polymeric substances (EPS), which can represent up to $70 \%$ of the sea ice POC pool [Krembs et al., 2002a; Meiners et al., 2003; 2004]. EPS are thought to serve in cell attachment and motility, act as a buffer against $\mathrm{pH} /$ chemical variations, provide protection from grazers and improve sea ice habitability [e.g., Krembs et al., 2002a; Meiners et al., 2003; Riedel et al., 2006; Underwood et al., 2010; Krembs et al. 2011]. Importantly, recent studies on Arctic fast ice have shown that EPS can be retained in sea ice during ice melt in spring when particulate organic carbon is lost from the ice into the underlying water [Riedel et al., 2006; Juhl et al., 2011]. This discontinuous export of organic matter from seasonal sea ice suggests that the released material changes in quality and quantity with the progression of the melt season, which in turn affects its biogeochemical cycling.

\subsection{Macro-nutrients in sea ice and in the water column}

All macro-nutrients, namely nitrate $\left(\mathrm{NO}_{3}{ }^{-}\right)$, nitrite $\left(\mathrm{NO}_{2}{ }^{-}\right)$, phosphate $\left(\mathrm{PO}_{4}{ }^{3-}\right)$ and silicic acid $\left(\mathrm{Si}(\mathrm{OH})_{4}\right)$, are dissolved in brine inclusions, with the notable exception of ammonium $\left(\mathrm{NH}_{4}^{+}\right)$. Therefore, nutrient concentrations in bulk ice $(C)$ follow equation (2). For, $\mathrm{NH}_{4}{ }^{+}$, one of the rare ions that can be trapped within ice crystals during freezing [Weeks, 2010], equation (1) does not apply and its dynamics are different from other nutrients. There are numerous examples of vertical nutrient profiles in sea ice in the literature [see Thomas et al., 2010, and references therein; and Figure 3, for indicative profiles]. They indicate that macronutrient concentrations in bulk ice are relatively low compared to seawater values. During the ice algal production period, from spring to fall, $C$ usually lies on or below the dilution line [e.g., Tison et al., 2008; Zhou et al., in revision], e.g., $C / S \leq C^{w} / S^{w}$ (no superscript refers to sea ice, superscript $w$ refers to seawater, $S$ is salinity), which indicates a net consumption by photosynthetic organisms, superimposed on the brine dynamics-driven signal. On some occasions, essentially in winter [e.g., Dieckmann et al., 1991; Zhou et al., in revision], $C$ is above the dilution line, which suggests significant remineralization. Ammonium concentrations are typically on or above the dilution line, which is 
due to $\mathrm{NH}_{4}{ }^{+}$entrapment into ice crystals and could also result from heterotrophic nitrogen remineralization.

Since bulk ice concentrations are small, macronutrients are quickly exhausted in the absence of external supply (see Section 2.4). In contrast, if nutrient supply is on-going, macro-nutrients in sea ice are hardly limiting. Equation (2) indicates that this is because nutrients are concentrated in brines $(e<<1)$, and $C^{b r}$ - the nutrient concentration experienced by ice algae - is much larger than the corresponding half-saturation concentration (the value below which ice algae start to significantly suffer from low nutrients) [Monod, 1949]. Nutrient limitation induces significant modification in ice algae metabolism, such as in their carbon content (increasing POC: $\mathrm{Chl} a$ and POC : PON ratios), in cell-specific lipid content and fatty acid composition, and in carbon isotopic composition, when limited by $\mathrm{CO}_{2}$ [Palmisano et al., 1988; McMinn et al., 1999; Mock and Gradinger, 2000; Gradinger, 2009]. The changes in cell composition can alter algae sinking rates as well as their aggregation potential, impacting on ice algal export [Riebesell et al., 1991; Michel et al., 1993].

After stabilization of the brine network, nutrient supply stops when air temperature approaches the freezing point. Hence, despite significant light levels, various chemical elements have been reported to limit ice algal production in Arctic sea ice in late spring / early summer: $\mathrm{N}$ in the Chukchi and Beaufort Seas, in June [Gradinger, 2009], and $\mathrm{Si}$ in the Canadian Arctic Archipelago in June [Lavoie et al., 2005]. Nutrient limitation of Antarctic sea ice algae has also been reported for both surface and bottom communities [e.g., Kristiansen et al., 1998; McMinn et al., 1999] but seems less widespread than in the Arctic, although it is not clear whether this is due to a lack of summer observations or to undocumented summer nutrient supply mechanisms. Strong currents, as tides in coastal regions, or the Antarctic Circumpolar Current, may contribute to nutrient supply by forced convection [Cota et al., 1987; Cota and Horne, 1989].

As supply mechanisms bring nutrients into the ice, seawater provides the ultimate constraint on nutrient availability for sea ice communities. Seawater nutrient concentrations feature strong regional variations, but in the Arctic, those are not well constrained: the World Ocean Atlas Climatology [Garcia et al., 2006] has almost no data coverage in the Arctic Basin, and riverine inputs of nutrients are poorly understood [Popova et al., 2012]. Some general features can however be found in the literature. The Atlantic Arctic is rather poor in nutrients, receiving northwardflowing surface waters, already exhausted in nutrients, especially silicic acid, while the Pacific Arctic receives much more nutrients, from the influence of nutrient-rich deep Pacific waters [Sakshaug, 2004]. High interannual variability in nutrient inventories and biological processes on the Arctic shelves, influenced by variable Pacific inflow, suggests a control of primary production on those shelves by nutrient availability [Michel et al. 2006 ; Apollonio and Matrai, 2011]. Nitrogen seems to be the primary liming nutrient in the Arctic Ocean and its peripheral seas [see Tremblay and Gagnon, 2009; and references therein]. Phosphorous limitation is likely in riverinfluenced waters, because Arctic rivers are relatively rich in nitrogen but poor in phosphate [Sakshaug, 2004]. However, the significance of riverine input might be limited because residual inorganic nutrients are exhausted before the riverine water advances into the Arctic Ocean [Tremblay and Gagnon, 2009]. The Southern Ocean and North Pacific Arctic waters are relatively rich in macro-nutrients [Garcia et al., 2006], because of the upwelling of nutrient-rich deep waters [Sakshaug et al., 2004], and these regions are considered as iron limited [see Boyd and Ellwood, 2010; and references therein]. While iron availability affects the photosynthesis and production of common Antarctic ice algal species, in situ sea ice concentrations are generally above iron half-saturation constants for these species [Pankowski and McMinn, 2009]. Therefore, in contrast to Southern Ocean phytoplankton, Antarctic sea ice algae are usually not iron limited [e.g., van der Merwe et al. 2009; Thomas et al., 2010]

\subsection{Trace metals}

In regions where iron $(\mathrm{Fe})$ is potentially limiting phytoplankton growth (Southern Ocean and North Pacific), the evidence of high concentrations of $\mathrm{Fe}$ in sea ice [Lannuzel et al., 2007; Aguilar-Islas et al., 2008] - much higher than in the water column - raised strong interest in the role of seasonal sea ice retreat as a 
potential trigger for phytoplankton blooms in Felimited surface waters [Lancelot et al., 2009]. Iron is important for photosynthesis and nutrient assimilation processes. Low $\mathrm{Fe}$ availability for phytoplankton reduces growth rates and abundance of large phytoplankton classes [Martin et al., 1991], because small phytoplankton groups have high surface area to volume ratios and assimilate $\mathrm{Fe}$ more efficiently than large phytoplankton [de Baar, 1994]. In regions where $\mathrm{Fe}$ is plentiful (like the Arctic ocean, due to the proximity of continents), the role of Fe release by sea ice is obviously minor.

The contribution of the potential mechanisms driving $\mathrm{Fe}$ cycling in sea ice is not yet fully understood [see Lannuzel et al, 2010 for a complete discussion]; here only the key elements are summarized. Firstly, observations from melted ice core sections indicate that $\mathrm{Fe}$ in sea ice is either dissolved in brine $(\mathrm{dFe})$ or found in the particulate form (PFe) [e.g., Lannuzel et al., 2007]. Hence, equation (2) is not applicable for Fe. Both forms exchange with each other: $\mathrm{dFe}$ is converted into PFe through assimilation by growing micro-algae and organic compounds sealed in the ice, including bacteria biofilms with a high affinity for Fe [Hassler and Schoemann, 2009]. Conversely, some PFe goes into dFe due to cell lysis, heterotrophic activity and photooxidation. Secondly, throughout winter, Fe-rich particulates, colloids and organic matter, are harvested by frazil crystals, rising through the water column towards the ice base, simultaneously with a net upwards component from Langmuir cells and wave field pumping [e.g., Garrison et al., 1983]. This should provide a $\mathrm{PFe}$-rich substrate at the time of incorporation into sea ice. Thirdly, the removal of $\mathrm{dFe}$ from brine by assimilation onto ice-attached, biogenic PFe [van der Merwe et al., 2009], combined with a supply of $\mathrm{dFe}$ from seawater to the ice due to brine mixing, can substantially increase the total concentration of $\mathrm{Fe}(\mathrm{dFe}+\mathrm{PFe})$ in sea ice as compared to seawater [Vancoppenolle et al., 2010]. Finally, since the large majority of dFe and $\mathrm{PFe}$ in marine systems is complexed by organic ligands [e.g., Rue and Bruland, 1995; Boye et al., 2001], the direct adsorption of uncomplexed $\mathrm{Fe}$ on sea ice is not expected to be significant.

The reported sources for $\mathrm{Fe}$ in the ocean include aeolian dust deposition [e.g., Wagener et al.,
2008], extraterrestrial dust [e.g., Johnson, 2001], sediment resuspension [e.g., Moore and Braucher, 2008], inputs from continental margins and icebergs [e.g., Raiswell et al., 2008] and hydrothermalism [e.g., Tagliabue et al., 2010]. In this context, sea ice is not a new source of $\mathrm{Fe}$, but rather an important seasonal Fe reservoir [van der Merwe et al., 2011b]. During the melt season, the release of the excess Fe stored in the sea ice coincidentally occurs when light and mixed layer depth are favourable to phytoplankton growth [van der Merwe et al., 2011b]. Hence, the seasonal $\mathrm{Fe}$ accumulation and release from sea ice enhance the availability and utilisation of $\mathrm{Fe}$. Most of the Fe released in the water colum sinks with organic matter, while a small part, associated with the micro-organisms and dead material remaining in suspension is incorporated at the onset of the new ice season.

The release of $\mathrm{Fe}$ by melting ice could partly contribute to large ice edge blooms [Arrigo et al., 2008a] in the Southern Ocean. Indeed, although much uncertainty exists, a modelling study by Lancelot et al. [2009] in the Antarctic sea ice zone suggests that the timing of sea ice formation, the uptake of $\mathrm{Fe}$ in growing ice from the different available sources and its subsequent transport by drifting ice are fundamental to predicting the location and magnitude of the Antarctic marginal ice zone (MIZ) production. This line of reasoning may also apply in other Fe-limited areas of icecovered waters, such as the Bering Sea.

Let us caution that, once released into the water column, Fe may not always be readily available to phytoplankton, with some forms being unavailable for assimilation in plankton. The socalled Fe bioavailability - presently difficult to predict - is a function of the physical and chemical forms of $\mathrm{Fe}$, as well as of the uptake strategies employed by the various biota to access Fe [Hassler and Schoemann, 2009].

As a stronger glacial $\mathrm{Fe}$ supply inducing an intensified nutrient utilization is one of the potential explanations for the strengthening of Southern Ocean $\mathrm{CO}_{2}$ uptake in glacial periods [Sigman et al., 2010], understanding $\mathrm{Fe}$ accumulation in sea ice, its release in the ocean by melting sea ice, and Fe bioavailability for phytoplankton, remains one of the crucial questions of present-day sea ice biogeochemistry. 
Note that the cycling of bio-essential $\mathrm{Fe}$ contrasts with other non-essential trace metals (such as molybdenum, barium, chromium and aluminium), which, like macro-nutrients, remain unchanged in proportion to ice salinity after their incorporation into sea ice [Lannuzel et al., 2011].

\subsection{Biological interactions with the water column}

Observations indicate: (i) phytoplankton blooms start under the ice [e.g., Arrigo et al., 2012] and then typically follow the summer ice retreat in the Arctic [Perrette et al., 2011], while only ice-edge blooms have been reported in the Southern Ocean [Smith and Nelson, 1985]; (ii) recent Arctic Ocean sea ice retreat is associated with a significant increase in pelagic primary production [Arrigo et al., 2008b; Tremblay et al., 2011]; and (iii) marine ecosystem shifts have occurred due to changing sea ice conditions, notably in the Bering Sea (Arctic) [Grebmeier et al., 2006] and in the West Antarctic Peninsula area [e.g., MontesHugo et al., 2009].

These observations support a significant role for sea ice on water column primary productivity, which can be mediated by physical and biogeochemical processes. First, sea ice, the material it contains (organic matter and sediments), and its snow cover control the incoming light in the upper ocean; while ice growth and melt affect the upper ocean stratification and nutrient supply [Tremblay and Gagnon, 2009]. Secondly, once released in the ocean, ice algae and the associated material influence pelagic biogeochemistry and food webs, through the seeding of phytoplankton blooms [e.g. Lancelot et al., 2009], heteorotrophic grazing, and organic matter export to depth, feeding the benthos [Constable et al., 2003].

Light transmission. As discussed above, sea ice, its snow cover [Perovich et al., 2002a] and particles stored within sea ice, mainly soot [Warren and Wiscombe, 1980] influence the surface albedo and the spectral transmission of light in waters under the ice cover. Light limitation of phytoplankton production in the presence of snow-covered sea ice is typically observed prior to significant melt [Fortier et al., 2002; Michel et al., 2006]. In addition, during the ice-algal bloom in Arctic first-year ice, the presence of an optically-dense biomass layer in the bottom ice contributes to reduce the available light in the upper ocean [e.g., Mundy et al., 2007]. Light limitation is also fundamental to the classic understanding that Arctic basins, where multiyear ice used to prevail year-round, are areas of low primary production.

The fate of the material released in the water column after sea ice melt is an important challenge [e.g., Tedesco et al., 2012], but the partitioning between seeding, grazing, and export is complicated and currently not well constrained. Sea ice constitutes a reservoir where primaryproduced biomass accumulates along a sizecontinuum ranging from dissolved, gel-like, to particulate fractions. Dissolved organic carbon concentrations is often higher than algal biomass, and exopolymeric substances can significantly contribute to the total organic carbon in sea ice [Krembs et al., 2002a; Riedel et al., 2006; 2008; Meiners et al., 2004; van der Merwe et al., 2009]. At the time of melt, most of the particulate organic material in the sea ice reservoir is released into surface waters since there is no top-down control (i.e., due to grazing by upper trophic level organisms) on the accumulation of biomass in the ice [Michel et al., 2002]. The strong pulse of particulate organic matter released into the water column can fuel planktonic food webs [Michel et al., 1996; Lizotte, 2001] or sink to the bottom [Riebesell et al., 1991; Fortier et al., 2002; Renaud et al., 2007]. Ultimately, the material that is not grazed or remineralized during its descent or at the seafloor can be stored in sediments. Many factors influence the quantity and the quality of the material reaching the seafloor, including water depth, morphological and physiological factors that influence cell coagulation sinking rates, water column processes that influence mixing and stratification, and top-down control by under-ice and water column grazers. Ice algae provide an important and essential food source for key pelagic herbivores [Søreide et al., 2010] for which egg production and stage development are synchronized to match the timing of the bloom [Fortier et al., 2002]. Therefore, a mismatch between the timing of the ice algal bloom and zooplankton grazing may shift the nature of the sinking organic material, from more fecal pellets to more fresh algal cells [Michel et al., 2006]. In addition, the timing and duration of the melt period also influences the quality of the 
material exported to the seafloor since rapid melt can favour a rapid export of intact algal cells to depth [Fortier et al., 2002; Michel et al., 2006]. Tracers associated with certain taxonomic groups that are well-preserved in sediments such as diatoms, dinoflagellates and foraminifera, are well-suited to serve as paleo-proxies. In sea ice, the high dominance of diatoms during the spring bloom has led to the recent development of the sea ice diatom-specific marker $\mathbb{I P}_{25}$ for paleoreconstructions of ice extent [Belt et al., 2007].

Arctic and Antarctic ice edge blooms. In the Arctic, ice edge blooms seem to be frequent, typically last 20 days in a $100 \mathrm{~km}$ band near the ice edge, but may last longer in some instances [Perrette et al., 2011]. As they are transient in space and time, quantifying their contribution to overall production is challenging. In the Arctic, increases in phytoplankton biomass and productivity associated with reductions in sea ice extent have been identified from satellite ocean colour observations. The annual pelagic primary production was $416 \mathrm{Tg} \mathrm{C} \mathrm{y}^{-1}$ over 1998-2002 and increased by $27.5 \mathrm{Tg} \mathrm{C} \mathrm{y}^{-1}$ each year between 2003 and 2007 [Arrigo et al., 2008b]. Southern Ocean ice-associated pelagic primary production occurs generally in the form of ice-edge blooms which are most productive on the continental shelves, and no sustained blooms occur in waters of depth $>1000 \mathrm{~m}$ [Smith and Comiso, 2008]. While the MIZs can show high primary production rates, mixed-layer depths are often not favourable to ice-edge bloom development. Therefore, productivity in the MIZ is often similar to open water productivity and the contribution of MIZ primary production to the overall Southern Ocean production is considered to be low [Arrigo et al., 2008a]. However, MIZ blooms can provide, at times and in distinct regions, a highly productive environment supporting higher trophic levels and biogeochemical cycling in the region [Smith and Nelson, 1985; Arrigo et al., 1998]. The release of $\mathrm{Fe}$ into the water column should also play a role [Lancelot et al., 2009].

Arctic ice-edge blooms can also be the continuation of under-ice blooms, which can develop when under-ice light conditions are favourable after surface melt onset [Fortier et al., 2002; Mundy et al., 2009] and can cover extensive areas [Arrigo et al., 2012]. These blooms can be highly productive and support high biomasses, indicating that current estimates of Arctic primary production are underestimated [Arrigo et al., 2012]. When present, melt ponds increase light transmission through sea ice by about one order of magnitude [Frey et al., 2011]. Under-ice phytoplankton blooms have not been reported in the Antarctic. Antarctic sea ice is virtually always snow-covered, has nearly no melt ponds, and hence the transmitted under-ice irradiance is arguably insufficient to support high phytoplankton growth rates.

Finally, the remnants of ice edge phytoplankton blooms can be trapped in sea ice during freezing if they encounter rising frazil ice crystals, and the timing and location of sea ice formation may affect the amount and quality of material (algae, particulate carbon, nutrients) physically incorporated into the sea ice [Garrison et al., 1983; Fritsen et al., 2008; Lannuzel et al., 2010].

The large-scale contribution of sea ice to primary productivity has been evaluated in a few instances and compared to water column values. While it is possible to estimate large-scale pelagic primary production from ocean color data [Arrigo et al., 2008 ; Pabi et al., 2008], this is not the case for sea ice. Consequently, estimates of large-scale primary production in sea ice derive from the extrapolation of in situ data [Legendre et al., 1992] and from numerical models [Arrigo et al., 1997; Deal et al., 2011], involving a number of assumptions. Therefore, sea ice primary production estimates have to be considered carefully. In the Arctic, the satellite-estimated contributions to primary production are $240 \mathrm{Tg} C$ $\mathrm{y}^{-1}$ over open ocean and $179 \mathrm{Tg} \mathrm{C} \mathrm{y}^{-1}$ for the marginal ice zones [Pabi et al., 2008]. The contribution of sea ice is estimated to range over 9-73 $\mathrm{Tg} \mathrm{C} \mathrm{y}{ }^{-1}$, from Chl a data [Legendre et al., 1992]; and to reach $15 \mathrm{Tg} \mathrm{C} \mathrm{y}^{-1}$ in 1992, from a model study [Deal et al., 2011]. The fraction of sea ice versus pelagic productivity is $\sim 10 \%$ on average but is larger in the Arctic Basin, and smaller in the seasonally ice covered seas [Deal et al., 2011]. In the Antarctic, $1795 \mathrm{Tg} \mathrm{C} \mathrm{y}^{-1}$ are produced in the open ocean, $114 \mathrm{Tg} \mathrm{C} \mathrm{y}^{-1}$ are produced in the marginal ice zones, and from 40 to $70 \mathrm{Tg} \mathrm{C} \mathrm{y}^{-1}$ are produced within the sea ice, based on observations of $\mathrm{Chl} a$ and modelling studies, respectively [Legendre et al., 1992; Arrigo et al., 1997]. Under-ice production is 
absent from those estimates, because those regions are beyond the reach of satellites.

\subsection{Inorganic carbon dynamics}

Inorganic carbon dynamics in sea ice are driven by brine dynamics, gas-exchanges at the brinesnow-atmosphere interfacial region [Delille et al., 2007; Miller et al, 2011b], carbonate chemistry in brines, $\mathrm{CaCO}_{3}$ precipitation [Dieckmann et al., 2008; 2010] and biological processes [Delille et al., 2007]. Dissolved inorganic carbon (DIC) and alkalinity (Alk) enter the sea ice system during formation. A large part of the DIC is lost via brine rejection and possibly through outgassing to the atmosphere. Carbonate system chemistry would as in the ocean alter the repartition of DIC between the aqueous $\mathrm{CO}_{2}$, and the carbonate $\left(\mathrm{CO}_{3}{ }^{2-}\right)$ and bicarbonate $\left(\mathrm{HCO}_{3}{ }^{-}\right)$ions [Thomas et al., 2010]. DIC can escape the liquid brine phase following the formation of $\mathrm{CO}_{2}$ - rich gas bubbles [Tison et al., 2002], by the precipitation of calcium carbonate $\left(\mathrm{CaCO}_{3} \cdot 6 \mathrm{H}_{2} \mathrm{O}\right)$; and through uptake by primary producers [Delille et al., 2007].

Gas exchanges. When sea ice was believed to be impermeable, the large-scale oceanatmosphere $\mathrm{CO}_{2}$ exchange $\left(\mathrm{FCO}_{2}\right)$ was thought to occur only during the open water season [Yager et al., 1995]. However, recent findings point to significant $\mathrm{CO}_{2}$ fluxes through sea ice [Delille, 2006; Nomura et al., 2010]. At this stage, observations suggest that the sea ice zone could be a source of atmospheric $\mathrm{CO}_{2}$ in winter [Miller et al., 2011b], and a sink in summer and fall [Else et al., 2008; Mucci et al., 2010], with a transition period in between [Delille, 2007; Nomura et al., 2010], and a net uptake from the sea ice zone on an annual basis [Rysgaard et al., 2011].

The atmosphere-ice flux of $\mathrm{CO}_{2}\left[\mathrm{~mol} \mathrm{C} /\left(\mathrm{m}^{2} . \mathrm{s}\right)\right]$ can be expressed as [Nomura et al., 2006]:

$$
F C O_{2}^{i c e}=k^{\mathrm{CO}_{2}} \alpha^{C O_{2}} a^{\text {eff }} \cdot\left(p C \mathrm{O}_{2}^{a}-p C \mathrm{O}_{2}^{b r}\right)
$$

where $\mathrm{k}^{\mathrm{CO} 2}$ is the $\mathrm{CO}_{2}$ transfer velocity across the brine-air interface $(\mathrm{m} / \mathrm{s}), a^{\mathrm{CO} 2}$ is the solubility of $\mathrm{CO}_{2}$ in surface brine $\left(\mathrm{mol} \mathrm{C} /\left(\mathrm{m}^{3}\right.\right.$.atm) ), $a^{\text {eff }}$ is the fraction of the ice surface occupied by brine (equal to brine volume if brine inclusions are assumed isotropic, less in the more realistic case), and $\mathrm{pCO}_{2}{ }^{\mathrm{a}}$ and $\mathrm{pCO}_{2}{ }^{\mathrm{br}}$ are the air and brine partial pressure of $\mathrm{CO}_{2}$ (atm), respectively.
Therefore, the small size of brine inclusions tends to reduce $\mathrm{FCO}_{2}{ }^{\text {ice }}$, while the large values of $\mathrm{pCO}_{2}{ }^{\text {br }}$ [Delille et al., 2007] tend to increase it.

A complete understanding of the seasonality of the large-scale $\mathrm{CO}_{2}$ flux $\left(\mathrm{FCO}_{2}\right)$ in the sea ice zones of the polar oceans is not achieved yet. $\mathrm{FCO}_{2}$ should follow:

$$
\mathrm{FCO}_{2}=A \cdot \mathrm{FCO}_{2}^{\text {ice }}+(1-A) \cdot \mathrm{FCO}_{2}^{\text {ow }}
$$

including sea ice and open water contributions $\left(\mathrm{FCO}_{2}{ }^{\mathrm{ow}}\right)$, weighted by ice concentration $A$. If brine inclusions are small enough for sea ice fluxes to be negligible and if the ocean responds linearly, as frequently assumed [Bates et al., 2006; Else et al., 2008], $\mathrm{FCO}_{2}$ could linearly decrease with ice concentration. However, lab experiments [Loose et al., 2009] indicate that such a relation is non-linear, although the underlying principles remain unclear. The processes that may contribute to non-linearities include dynamical fluxes through the sea ice cover [e.g., Nomura et al., 2010; Papakyriakou and Miller, 2011], but also changes in convective activity or stratification in the water column [Loose and Schlosser, 2011]. In addition, the sign of $\mathrm{FCO}_{2}$ changes with location and time of the season, whereas the absolute value of $\mathrm{FCO}_{2}$ may span several orders of magnitude. For instance, much larger $\mathrm{FCO}_{2}$ in the sea ice zone than in typical open water situations were observed, in regions of large sea ice concentrations, notably in the vicinity of polynyas [Else et al., 2011].

The fluxes over sea ice are notoriously difficult to estimate, and methodological uncertainties certainly play a role [see Loose et al, 2011; for a detailed discussion]. $\mathrm{FCO}_{2}$ has been estimated by applying bulk formulae to atmosphere-ocean $\mathrm{pCO}_{2}$ differences, linearly weighted by ice concentration [e.g., Bates et al., 2006; Else et al., 2008], which inherently neglects the contribution of sea ice fluxes to $\mathrm{FCO}_{2}$. Chambers provide a direct estimation of $\mathrm{FCO}_{2}$ ice [e.g., Nomura et al., 2010], but those devices affect gas transport, measure small-scale fluxes, and thermally alter the sea-ice system. The eddy covariance method [e.g., Papakyriakou and Miller, 2011] provides an integrated, larger-scale measure of $\mathrm{FCO}_{2}$ but suffers from a number of corrections. In addition, the horizontal footprint of eddy covariance 
retrievals and how they integrate sea ice, cracks and leads is difficult to assess. Clarifying the $\mathrm{CO}_{2}$ exchanges in ice-covered seas, as well as understanding the differences arising from different methods is a challenge for future research.

$\mathrm{CaCO}_{3}$ precipitation. Vertical profiles of DIC and Alk in sea ice are qualitatively very close to salinity. However, in depth analyses reveal an Alk:DIC ratio in sea ice that is sometimes higher than in seawater [e.g., Rysgaard et al., 2007; Geilfus et al., in press], which supports a significant role for precipitation and storage of $\mathrm{CaCO}_{3}$ crystals within sea ice [Rysgaard et al, 2007]. $\mathrm{CaCO}_{3}$ precipitation is theoretically possible below $-2.2^{\circ} \mathrm{C}$ [e.g., Assur, 1958], well above typically observed sea ice temperatures. $\mathrm{CaCO}_{3}$ would hardly be limited by $\mathrm{Ca}$ availability, since the latter is abundant in seawater, with concentration reaching $\sim 10,000 \quad \mathrm{mmol} / \mathrm{m}^{3}$, [Sarmiento and Gruber, 2006], i.e., much more than what is required to precipitate significant amounts of $\mathrm{CaCO}_{3}$. Ikaite crystals, thermodynamically stable at $-4.5^{\circ} \mathrm{C}$, have been observed in Weddell Sea and Arctic sea ice [Dieckmann et al., 2008; 2010], which suggests that other anhydrous carbonate mineral phases (calcite, aragonite, vaterite), stable at higher temperatures, could be kinetically inhibited [Thomas et al., 2010]. However, it has proven difficult to reproduce $\mathrm{CaCO}_{3}$ precipitation in artificial sea ice growth experiments, highlighting that the authigenesis of ikaite in sea ice is not yet fully understood [e.g., Fischer et al., 2012]. Indeed, little is known about the spatial and temporal occurrence of ikaite precipitates in sea ice, but as summarized by Geilfus et al. [in press], it appears that the ikaite stability field is limited to near-freezing temperatures and below, and is favoured by alkaline conditions, elevated phosphate concentrations and by the presence of certain additives like amino-acids.

Export of $\mathrm{CO}_{2}$ to depth and net air-sea $\mathrm{CO}_{2}$ flux. In a recent compilation, Rysgaard et al. [2011] estimated the annual rejection of DIC into the ocean due to ice formation to be $324 \mathrm{Tg} \mathrm{C} \mathrm{y}^{-1}$ integrated over both polar oceans $\left(>62^{\circ} \mathrm{N}\right.$ and $>50^{\circ} \mathrm{S}$ ). However, the repartition of this excess DIC between an atmospheric efflux and the export below the mixed layer is not well constrained. Sea ice melt reduces surface seawater $\mathrm{pCO}_{2}$. In the absence of $\mathrm{CaCO}_{3}$ storage in sea ice, and assuming that all brine is exported below the mixed layer in winter, restoring this reduced seawater $\mathrm{pCO}_{2}$ due to sea ice melt to its equilibrium value before freeze up would require a net air-sea flux of about $33 \mathrm{Tg} \mathrm{C} \mathrm{y}^{-1}$, integrated over both the Arctic and Southern Oceans [Rysgaard et al., 2011].

The precipitation and storage of $\mathrm{CaCO}_{3}$ in sea ice could enhance this annual net uptake of DIC in the polar oceans. Rysgaard et al. [2007] suggest that, if the brine enriched in $\mathrm{CO}_{2}$ sinks below the mixed layer when ice grows, the release of sea ice melt water with increased Alk/DIC ratio would increase Alk in surface waters, reduce oceanic $\mathrm{pCO}_{2}$ in summer and promote a further uptake of atmospheric $\mathrm{CO}_{2}$ by the ocean. This abiotic DIC pump [see Loose et al., 2011; for a discussion] would represent a sink of $83 \mathrm{Tg} \mathrm{C} \mathrm{y}^{-1}$ of atmospheric $\mathrm{CO}_{2}$ integrated over both Arctic and Southern Oceans, in the context of the Rysgaard et al. [2011] simple computations, to be compared to the overall uptake of $200 \mathrm{Tg} \mathrm{C} \mathrm{y}^{-1}$ of atmospheric $\mathrm{CO}_{2}$ by open water polar oceans [Takahashi et al., 2009].

However, the above assessment of the uptake of atmospheric $\mathrm{CO}_{2}$ in the polar oceans is built on two assumptions: (i) the produced $\mathrm{CO}_{2}$ is released to the underlying water and entrained to deeper waters together with brines, while (ii) $\mathrm{CaCO}_{3}$ crystals remain trapped within the ice matrix. The first assumption is not guaranteed at this stage, because $\mathrm{CaCO}_{3}$ precipitation is not always simultaneous with the sinking of brine below the mixed layer. Besides, $\mathrm{CaCO}_{3}$ precipitation produces $\mathrm{CO}_{2}$, and if this $\mathrm{CO}_{2}$ finds a pathway towards the atmosphere, for instance, via a permeable brine network, then the excess carbon could be instead exported into the atmosphere [Geilfus, 2011]. Therefore, a robust assessment of the role of $\mathrm{CaCO}_{3}$ precipitation as a sink of atmospheric $\mathrm{CO}_{2}$ requires better constraints on the timing and location of $\mathrm{CaCO}_{3}$ precipitation. The second assumption is also uncertain, because the increase in Alk/DIC ratio reported by Rysgaard et al. [2007] has not been confirmed in other comparable studies [Miller et al., 2011b; Geilfus et al., 2012].

More investigations on the various aspects of the carbonate chemistry in sea ice and the polar oceans are required to better constrain $\mathrm{CO}_{2}$ 
exchanges in the polar oceans. The absence of a proper representation of carbon cycling in the sea ice zone in present Earth system models may be at the source of a fundamental flaw in our understanding of the role of polar seas in the global ocean $\mathrm{CO}_{2}$ sink: observations of ocean $\mathrm{pCO}_{2}$ suggest that the Southern Ocean sea ice zone is a source for $\mathrm{CO}_{2}$ [Takahashi et al., 2009] while ocean model inversions suggest an oceanic sink for $\mathrm{CO}_{2}$ in the sea ice zone [Gruber et al., 2009].

\subsection{Other climatically significant gases: DMS,} $\mathrm{N}_{2} \mathrm{O}$ and $\mathrm{CH}_{4}$

Sea ice has been considered as a potential important source of DMS in the polar oceans when extremely high concentrations (up to three orders of magnitude higher than background sub-nanomolar seawater concentrations) of its precursor DMSP were found in Antarctic [Kirst et al., 1991] and Arctic [Levasseur et al., 1994] sea ice cores. The production of DMSP in sea ice is favored by the high concentration of its producers (i.e., ice microalgae) [Trevena et al., 2003; Gambaro et al., 2004] and by the extreme environmental conditions of the sea ice habitat. The high salt concentrations and low temperatures that prevail in sea ice favour high intracellular contents in DMSP [Kirst et al., 1991; DiTullio et al., 1998] which is known to act as a cryoprotectant and osmoregulator [Stefels, 2000; Stefels et al., 2007]. DMS, the enzymatic cleavage product of DMSP, has long remained difficult to measure in sea ice, since the thawing of the ice samples and the subsequent osmotic shock result in cell lysis and in the artificial conversion of DMSP into DMS [Stefels et al., 2012]. However, techniques such as acidification of samples [Trevena and Jones, 2006], drycrushing and addition of stable isotopes [Tison et al., 2010; Stefels et al., 2012], have all been successfully used to confirm the important stocks of DMS in sea ice.

Sea ice concentrations in DMS and DMSP are not only extremely high but also extremely variable, as illustrated by high-resolution vertical profiles [Trevena et al., 2000; 2003; Tison et al., 2010] and strong regional and seasonal variations [e.g., Turner et al., 1995 ; Curran and Jones, 2000]. This variability results from complex interactions between the physical, biological and chemical processes that drive the DMS(P) cycle
[Stefels et al., 2007], and sea ice thermodynamic processes. Many of these processes are difficult to follow separately in field studies and remain poorly quantified and understood. Some authors [Levasseur et al., 1994; Trevena et al., 2000; Tison et al., 2010] have shown the strong influence of community composition on the DMS and DMSP profiles (the biosynthesis of DMSP being species specific). Tison et al. [2010] described the influence of temporal changes in brine volume and brine salinity on the vertical migration of DMS and DMSP within sea ice. The broadening of brine channels, which facilitates access to grazers, and the decrease in brine salinity during ice melt both favour DMSP release from ice microalgae cells. Yet to be confirmed, an increase in DMS production would also be favored by oxidative stress in the spring when enhanced biological activity leads to reduced $\mathrm{CO}_{2}$ and increased $\mathrm{O}_{2}$ concentrations in the ice [Delille et al., 2007]. In that case, DMS(P) would scavenge hydroxyl radicals and other reactive oxygen species following an antioxidant cascade as suggested by Sunda et al. [2002]. Many uncertainties remain about the role played by dimethylsulfoxide (DMSO) in the sea ice DMS(P) cycle [Lee et al., 2001]. High concentrations of DMSO have been reported in sea ice [Lee et al., 2001; Brabant et al., 2011]. However, the physiological roles played by DMSO in ice microalgae cells [Lee et al., 2001] or the dynamics of photochemical and bacterial oxydation of DMS into DMSO in the sea ice column require further investigations.

Melting of sea ice considerably increases the concentration of DMS in surface waters of the polar ocean either through the direct release of DMS $(P)$ or through the onset of phytoplankton blooms [Levasseur et al., 1994; Curran and Jones, 2000; Trevena and Jones, 2006; Tison et al., 2010; Trevena and Jones, 2012]. These pulses of DMS $(P)$ may considerably increase the regional oceanic DMS emissions [see Levasseur et al., 1994; Tison et al., 2010 and Trevena and Jones, 2012 for estimates]. Also of particular interest is the direct venting of DMS from sea ice. Very few attempts of measuring sea iceatmosphere DMS fluxes have been made. Zemmelink et al. [2008], using the Relaxed Eddy Accumulation method, reported important fluxes (up to $11 \mu \mathrm{mol}$ DMS $\mathrm{m}^{-2} \mathrm{~d}^{-1}$ ) from multi-year ice in the Weddell Sea with very productive ice 
microalgae communities. Using an accumulation chamber techinque, Nomura et al. [2012] reported fluxes ranging from 0.1 to $5.3 \mu \mathrm{mol} D M S$ $\mathrm{m}^{-2} \mathrm{~d}^{-1}$ from landfast multi-year ice off the Dronning Maud Land, in the Southern Ocean. The two studies show that the direct venting of DMS from sea ice may represent an additional significant source of DMS for the polar atmosphere. However, these regional fluxes measured over specific sea ice types cannot be extrapolated to the whole Arctic and Antarctic sea ice cover. Therefore, the contribution of sea ice to the global DMS emissions is currently unknown.

Two other powerful greenhouse gases recently focussed attention in the sea ice zone, namely methane $\left(\mathrm{CH}_{4}\right)$ and nitrous oxide $\left(\mathrm{N}_{2} \mathrm{O}\right)$. Several recent studies indicate significant sources of $\mathrm{CH}_{4}$ in the Arctic Ocean [e.g., Damm et al., 2010; Shakhova et al., 2009; Kort et al., 2012]. A primary source of $\mathrm{CH}_{4}$ are the East Siberian shelf sediments, venting methane to the surface, through the sea ice zone, reaching an annual contribution of $90 \mathrm{Tg} \mathrm{y}^{-1}$, about $15 \%$ of human emissions [Shakhova et al., 2009]. A second source seems to be associated with the surface waters of the sea ice zone, which were found to emit methane at a rate of $\sim 2 \mathrm{mg} \mathrm{CH}_{4} \mathrm{~m}^{-2} \mathrm{~d}^{-1}$, in fall and spring, near open water and fractured regions of the sea ice zone [Kort et al., 2012], a value that is comparable with emissions from the Siberian shelves. The sea ice zone could also biologically produce $\mathrm{CH}_{4}$ if nitrate is depleted but phosphate is available as a $P$ source (as occurring in Pacific waters of the Arctic Ocean) [Karl et al., 2008; Damm et al., 2010]. A low N:P ratio enhances the ability of bacteria to compete for phosphate while the phytoplankton metabolite DMSP is utilized as a $\mathrm{C}$ source. During the process, methyl-phosphonate is converted into methane, without requiring anoxia [Karl et al, 2008]. Hence, there are potentially important methane cycle processes in the sea ice zone, however how they function and how they relate to sea ice is not clear at this stage. For $\mathrm{N}_{2} \mathrm{O}$, the role of sea ice is even less clear. $\mathrm{N}_{2} \mathrm{O}$ is a powerful greenhouse gas also involved in stratospheric ozone depletion. $\mathrm{N}_{2} \mathrm{O}$ can be produced within sea ice, as suggested by studies on ammonium oxidation and anaerobic bacterial cultures [Priscu et al., 1990]. $\mathrm{N}_{2} \mathrm{O}$ production was also found to possibly occur in $\mathrm{O}_{2}$ depleted microenvironments in (sub-) Arctic sea ice, via denitrification [Kaartokallio, 2001; Rysgaard and Glud, 2004]. For the time being, only one study presents $\mathrm{N}_{2} \mathrm{O}$ measurement within sea ice [Randall et al., 2012], pointing out that sea ice formation and melt have the potential to generate sea-air or air-sea fluxes of $\mathrm{N}_{2} \mathrm{O}$, respectively, but how this could affect the large-scale $\mathrm{N}_{2} \mathrm{O}$ cycle is not understood at the moment.

\subsection{Sea ice surface, bromine and tropospheric ozone chemistry}

The properties of the sea ice surface and snow cover provide major controls to the bromine $(\mathrm{Br})$ and ozone $\left(\mathrm{O}_{3}\right)$ chemistry in the polar atmospheric boundary layer [Rankin et al., 2002; Kaleschke et al., 2004; Jones et al., 2006; Simpson et al., 2007; Yang et al., 2008; Nghiem et al., 2012], but mechanisms are not yet clear. The surface of first-year ice is generally more saline than that of multi-year ice, due to contributions from sea ice brine, flooding seawater and deposited sea salt from nearby leads and polynyas, while the surface of Arctic multi-year ice is washed by flushing in summer and is therefore almost fresh [e.g., Vancoppenolle et al., 2007]. In addition, the surface of newly formed ice is frequently covered by frost flowers, which are vapour-deposited ice crystals, wicking brine from the sea ice [Perovich and RichterMenge, 1994; Domine et al., 2005]. Frost flowers can develop within a few hours when the ice surface temperature is much larger than that of the overlying air, as is the case for newly forming sea ice [Style and Worster, 2009]. Frost flowers last a few days at most, then disappear, covered with condensation (hoar), entrained in winds, covered by snowfall, or flooded with seawater [see Douglas et al., 2012; and references therein].

The surface of both young and older first-year ice could be a major source of reactive $\mathrm{Br}$ during polar spring [Rankin et al., 2002]. During that season, an exponential increase in reactive halogens ("bromine explosions") - of which bromine monoxide $(\mathrm{BrO})$ is an indicator - induces (i) a boundary-layer ozone depletion and (ii) mercury deposition in the polar regions [see, e.g., Simpson et al., 2007; and references therein]. Frost flowers [Rankin et al., 2002] were the first candidate for the strong $\mathrm{BrO}$ source, because of their high content in brine, a potentially large specific surface area, and the associated 
enrichment in major ions compared to seawater [Douglas et al., 2012]. Backtracking atmospheric parcel trajectories identified young ice regions as sources of bromine explosions and ozone depletion in the Antarctic sea ice zone [Kaleschke et al., 2004; Jones et al., 2006]. First-year ice surfaces, rather than only frost flowers, are now considered to provide the source of $\mathrm{BrO}$, as the specific surface area of frost flowers is not as large as initially expected [Domine et al., 2005]. In addition, low correlations between potential frost flowers and $\mathrm{BrO}$ anomalies, were found in an Arctic BrO backtracking exercise, while much higher correlations were found with first-year sea ice [Simpson et al., 2007]. As all estimates of frost flower distributions used in the aforementioned studies are indirect (based on temperature), the actual $\mathrm{BrO}$ source in the sea ice zone remains unclearly identified.

The sea ice surface seems also to be a source of sea-salt aerosols to the atmosphere during polar winter [Rankin et al., 2002]. Sea salt aerosols in glacial ice cores, in particular sea salt sodium, are used as sea ice proxies [Wolff et al., 2006]. Surprisingly, a more extensive sea ice cover induces more sea salt recorded in Antarctic continental ice cores for present conditions [lizuka et al., 2008], which is attributed to the highly saline frost flowers [Rankin et al., 2002] or to first-year, snow-covered sea ice. Snow lying on sea ice is a potentially important source of sea salt aerosol, as small snow particles, rich in salts, can be easily lifted into the air though blowingsnow events [Yang et al., 2008].

\section{Modelling and up-scaling the role of sea ice in the marine biogeochemical cycles}

The interactions between sea ice and the global marine biogeochemical cycles, outlined in the previous sections, are not well represented in Earth system models. Present large-scale models view sea ice as biologically and chemically inert and impervious to gas exchange. The incorporation of a proper representation of polar biogeochemical processes into largescale ocean modelling systems will help to better assess the role of sea ice in the polar marine biogeochemical cycles. It should also help to identify, if not to resolve, some of the problems and uncertainties of those models. For example, the degree of realism of large-scale ocean modelling systems in terms of ocean biological productivity seems to be systematically worse in polar regions than elsewhere. For instance, the sign of the projected future change in Arctic primary productivity in response to climate change is not consistent among different Earth system models [Steinacher et al., 2010]. Models also do not agree on whether light or nutrients limit primary production in the contemporary Arctic Ocean, due to inter-model differences in ice and ocean physics [Popova et al., 2010; 2012]. In addition, the simulated stocks of heterotrophic consumers in the Arctic Ocean seem to be systematically underestimated, likely due to a lack of a model ice algal compartment [Zhang et al., 2010]. Finally, the sign of the reconstructed atmosphere-ocean $\mathrm{CO}_{2}$ flux is opposite to observations in the Southern Ocean sea ice zone [Gruber et al., 2009].

Ocean modelling systems (see Figure 4a) typically have three components. The blue component represents ocean physics: ocean circulation, salinity, temperature, light, etc. [e.g., Madec and the NEMO team, 2008]. The white component includes sea ice, its growth, melt and drift [e.g., Hunke and Lipscomb, 2010; Vancoppenolle et al., 2012]. The green component includes a representation of the response of ocean microbial communities to changing environmental factors and of their impact on nutrients and trace metals [e.g., Aumont et al., 2003]. These three components are coupled, by exchanging energy, momentum and material.

Research is ongoing to introduce a representation of specific biogeochemical processes in the sea ice zone, with a number of modelling attempts, made in various regions and using different approaches (see Table 2), all directed towards the development of a representation of sea ice processes in large-scale ice-ocean models used for climate and marine biogeochemical simulations.

These developments must fit with the existing physical sea ice models. In these models, the changes in state variables are typically represented as the sum of the contributions of (i) vertical processes (growth and melt, sources and sink terms, ...), (ii) horizontal transport, and (iii) mechanical redistribution by deformation processes (opening, ridging and rafting) (see Figure 4b). As subgrid-scale variations in state 
variables are usually large, in particular for ice thickness, sea ice state variables are often represented as probability density functions, which, once discretized, correspond to so-called thickness categories [Thorndike et al., 1975; Bitz et al., 2001]. The fundamental probability density function is the ice thickness distribution $g(h)$, introduced by Thorndike et al. [1975] and representing the fractional area of the grid cell covered by ice of thickness $h$. To each depthdependent (z) sea ice field (including biochemical tracers), must correspond a distribution function $x(z, h)=C(z, h) g(h)$, following an equation of the type:

$$
\frac{\partial x}{\partial t}=-\nabla \cdot(x \boldsymbol{u})+\Psi^{x}-\frac{\partial}{\partial h}(f x)+\Theta^{x}
$$

where the terms on the right-hand side represent horizontal transport by horizontal velocity $\mathbf{u}$; mechanical redistribution $\left(\Psi^{\times}\right)$; transport in thickness space with $f=f(h)$ the vertical ice growth-melt rate; and vertical processes $\left(\theta^{\times}\right)$, respectively. Chla is highly spatially variable (see Section 2.3), hence accounting for its subgridscale variations is necessary. In addition, observations of $\mathrm{Chl}$ a distribution in Arctic and Antarctic sea ice [Gradinger, 2009; Meiners et al., 2012] indicate a significant contribution of bottom, internal, and surface algal communities at global scales, which suggests that vertically multi-layer formulations are required. In addition, Meiners et al. [2012] suggest that ridging and rafting play a significant role in the vertical redistribution of biomass.

One-dimensional (1D) biogeochemical sea ice models have been developed to understand vertical processes in isolation $\left(\theta^{\star}\right)$. These models (see Figure 4c) can be viewed as testing tools focussing on undeformed sea ice and can be used in a single location but not globally. Originally inspired from ocean biogeochemistry models, they are based on simple N-P formulations [see, e.g., Sarmiento and Gruber, 2006] and include (i) a single plankton group (diatoms) located at a prescribed depth in the ice (surface or bottom), (ii) one or several limiting nutrients, assimilated by ice algae with prescribed elemental (Redfield) ratios, and simple physics [Arrigo et al., 1993; Lavoie et al., 2005;
Jin et al., 2006; Saenz and Arrigo, 2012]. Those 1D models reasonably well simulate Arctic and the Antarctic sea ice algal developments over a few months. However, they also suffer from a number of drawbacks. First, the nutrient fluxes are based on simple formulations and do not account for brine transport. Consequently, the location of ice algal growth has to be prescribed, either at the base [e.g., Lavoie et al., 2005] or at the top of the ice cover [e.g., Arrigo et al., 1997; Saenz and Arrigo, 2012], and therefore the models are not general enough to handle both Arctic and Antarctic situations. Vancoppenolle et al. [2010] and Jeffery et al. [2011], have developed schemes to couple dissolved tracers to brine dynamics, and applied their model to successful simulations of silicate concentrations and salinity, respectively, but their approach has not yet been coupled to formulations of ecodynamics.

In addition, the required complexity for the radiative transfer component is not known. There are instances of mono-band [e.g., Lavoie et al., 2005] or multi-band schemes [Arrigo et al., 1993] in the literature, but all suffer from uncertainties, the largest being associated with the optical properties of snow [Pogson et al., 2011]. Furthermore, the required components for proper eco-dynamics are not known either. Most models have N-P modules only. Tedesco et al. [2010], using a more advanced biogeochemical component (two algal species, varying nutrient quotas in algal cells), showed that so-called survivors, i.e., single algal cells surviving adverse environmental conditions, can significantly contribute to ice algal production. Furthermore, no model at this stage includes organic matter, while organic matter storage in sea ice is quite large, with important consequences for nutrient remineralization [Meiners et al., 2008]. Finally, a $1 \mathrm{D}$ representation of gas dynamics in sea ice has been applied to Ar, underlining the important role of bubbles [Moreau et al., in revision], but has not yet been applied to other climatically significant biogases.

1D models have been coupled to water column models [Lavoie et al., 2009; Tedesco et al., 2012], showing that sea ice can substantially increase annual primary production, and contribute to the triggering of phytoplankton blooms, via the drastic increase in irradiance 
associated with ice retreat, water column stratification, or seeding of phytoplankton blooms. In the latter case, the potential role of ice algae depends on their viability, as well as on their degree of aggregation in the water column, controlling organic matter export to depth [Tedesco et al., 2012].

\section{Some groups have already included an ice} algal component in regional 3D ocean modelling systems. The ice algae model of Jin et al. [2006] has been included into a large-scale ocean modelling system running at regional scales [Deal et al., 2011; Jin et al., 2012], while an N-P-Z 3D ice-ocean model has been applied to the Hudson Bay [Sibert et al., 2011]. These studies indicate a moderate role for ice algae in the Arctic carbon cycle, reaching $15 \%$ of the total Arctic production [Deal et al., 2011]. In addition, these studies also suggest a key role for nutrients, but the model ice physics used to simulate nutrients are incomplete. In the Southern Ocean, prescribed Fe concentrations have been added in a 3D ice-ocean model [Lancelot et al., 2009], suggesting significant spatio-temporal controls of phytoplankton by sea ice Fe release.

\section{Discussion and outlook}

Recent observations point out active biogeochemical processes specific to the sea ice zone, involving primary production in the ice and the water, $\mathrm{CO}_{2}$ exchanges through sea ice, $\mathrm{CaCO}_{3}$ precipitation in the ice, export to depth of carbon-rich seawater, Fe release in oligotrophic regions of the ocean, and intense $\mathrm{DMS}, \mathrm{CH}_{4}$ and $\mathrm{BrO}$ emissions, all in tight interactions with the physical sea ice environment. Both polar regions are believed to be among the most sensitive places on Earth, where anthropogenic changes will be the most pronounced, and its impacts will be the largest and occur the earliest. Anthropogenic impacts include not only the rise in atmospheric and oceanic temperatures, and changes in ice extent and volume, but also changes in atmospheric chemistry [Simpson et al., 2007], pelagic primary production [e.g., Steinacher et al., 2010], ocean acidity [e.g., Doney et al., 2009], and shifts in marine ecosystems, as already observed today [e.g., Grebmeier et al., 2006]. Uncertainties in these large-scale changes, even in their sign for some of them, are large, and therefore, a sound understanding of the sea ice zone processes and how they affect the Earth system at large scales is highly necessary.

Some physical processes of high relevance for biogeochemistry are not well documented, like the nutrient supply mechanisms (brine transport), the radiative transfer in ice-covered oceans, and the formation of pressure ridges and their impact on ice algae. The key parameters that characterize biogeochemical processes of the sea ice zone discussed in Section 3 are not properly quantified at the relevant scales. These processes are: primary production in sea ice, the fate of ice algae in the water column after ice melt, gas exchanges, the precipitation of $\mathrm{CaCO}_{3}$ in sea ice, and the emission of $\mathrm{CH}_{4}, \mathrm{BrO}$, and DMS by the sea ice zone.

Progress in understanding biogeochemistry of the sea ice zone is limited due to harsh environmental conditions and expensive logistics required to access these areas. Furthermore, under-ice habitats, as well as biological and chemical properties of sea ice can hardly be observed from space. The classical sea ice sampling methods - ice coring and brine sackhole sampling - destroy the object of study. As physical, chemical and biological sea ice properties feature high horizontal variability at the meter scale, this complicates the interpretation of ice-core based time-series of observations. Spatial variability also hampers the upscaling of in situ observations at geophysical scales. In addition, ice coring involves the loss of brine and associated material in the permeable sections of the cores [Notz et al., 2005]. Finally, brine sackhole sampling implies some modification of the brine on its path to the hole, including the loss of particulate material; an integration of brine originating from various depths; and some exchange with the atmosphere [Thomas et al., 2010].

Novel and emerging technologies and methods, including the use of Remotely Operated Vehicles (ROV) and Autonomous Underwater Vehicles (AUV) instrumented with up-ward looking sonars and optical sensors, promise measurements of physical (e.g., under-ice topography) and biological (e.g., transmitted under-ice irradiance used as proxy for ice algal biomass) parameters on ecological and biogeochemical relevant scales 
[Mundy et al., 2007; Nicolaus et al., 2012; Williams et al., submitted].

Earth system models already represent admittedly not optimally - the physical processes that affect the pelagic ecosystems in the sea ice zone, i.e., the strong light attenuation and the reduced wind stirring of the mixed layer. However, they do not yet represent the biogeochemical processes that are specific to the sea ice zone. For instance, these models currently miss, the ice-associated production, which provides a food source for the upper trophic levels early in the season. Future projections performed with these models omit significant processes, while future ice conditions will change the seasonality of ice algae and phytoplankton. For instance, Tedesco et al., [2012], using a 1D ice-ocean model under a mild future climate scenario, project a more productive sea ice community, but less phytoplankton growth. This is because ice retreat occurs when light is less favourable to phytoplankton in a deep mixed layer. As far as other tracers are concerned, there have been very few attempts to simulate them. Both process and large-scale models will help us to identify the key processes and parameters that need to be properly monitored to evaluate the impacts of anthropogenic changes on polar climate, atmospheric chemistry, marine biogeochemistry and marine ecosystems.

At this stage, large-scale models are the most promising tools to improve the understanding of the role of sea ice in polar marine biogeochemistry. Present estimates indicate a small but significant contribution of sea ice algae to the total water column production, with a relative contribution depending on the region. Under-ice blooms may significantly contribute to primary production in the sea ice zone, and they may increase in the future, but they are unaccounted for in present estimates. Measurements and modelling of primary production under the ice in the central Arctic and on the shelves require immediate attention.

Of course, research in this domain is only beginning and large gaps in our understanding remain. These should be addressed in the next few years by collecting more in situ data particularly from under-sampled ice types, as multi-year ice and deformed ice -, by improving observing systems, especially at scales larger than the diameter of an ice core, by collecting glacial and marine sediment core data, by exploring the potential of remote sensing techniques, and by developing process models and large-scale parameterizations for Earth system models.

Sea ice proxies trace information of past sea ice characteristics at climate time scales, mostly based on biogeochemical properties of marine sediment cores. Deriving from biogeochemical processes in the sea ice zone, sea ice proxies will not only benefit from the upcoming better understanding of polar marine biogeochemistry, but also contribute to bracket its sensitivity to and impact on climatic and marine biogeochemical changes.

\section{Acknowledgements}

This article was written under the auspices of: the BIGSOUTH program, funded by the Belgian Federal Science Policy Office; BASICS (in IPY) - Biogeochemistry of Arctic and Antarctic Sea and the Climate System and BEPSI Biogeochemical Exchange Processes at the Sea-Ice Interfaces, SCOR Working Group. MV acknowledges financial support through the $7^{\text {n }}$ research program of European Union FP7/PEOPLE-2012-CIG BISICLO ( \#321938). KM acknowledges support by the Australian Governments Cooperative Research Centres Program through the Antarctic Climate and Ecosystems Cooperative Research Centre. JLT and BD acknowledge FNRS-FRFC contract \#2.4649.07 and F. Brabant was funded by an FNRS-FRIA PhD grant. BD is a Research Associate of the FRS-FNRS.

\section{References}

Ackley, S. F., and C. W. Sullivan (1994), Physical controls on the development and characteristics of Antarctic sea ice biological communities - a review and synthesis. Deep-Sea Research I, 41, 1583-1604.

Aguilar-Islas, A.M., R. D. Rember, C. W. Mordy, and J. Wu. (2008). Sea ice-derived dissolved iron and its potential influence on the spring algal bloom in the Bering Sea. Geophysical Research Letters, 35, L24601, doi:10.1029/2008GL035736.

Andreas, E. L. and Ackley, S. F. (1982). On the differences in ablation seasons of Arctic and Antarctic sea ice. Journal of Atmospheric Sciences, 39, 440-447.

Apollonio, S. and P. Matrai (2011). Marine primary production in the Canadian Arctic, 1956, 1961-1963. Polar Biology, 34, 767-774. doi: 10.1007/s00300-010-0928-3.

Armand, L. K. and Leventer, A. (2010). Palaeo Sea Ice Distribution and Reconstruction Derived from the Geological Record, In: Sea Ice, Second Edition (eds D. N. Thomas and 
G. S. Dieckmann), pp. 469-530, Wiley-Blackwell, Oxford, UK.

Armour, K. C., I. Eisenman, E. Blanchard-Wrigglesworth, K. E. McCusker, and C. M. Bitz (2011). The reversibility of sea ice loss in a state-of-the-art climate model. Geophysical Research Letters, 38, L16705, doi:10.1029/2011GL048739.

Arrigo, K. R., D. K. Perovich, R. S. Pickart, Z. W. Brown, G. L. van Dijken, K. E. Lowry, M. M. Mills, M. A. Palmer, W. M. Balch, F. Bahr, N. R. Bates, C. Benitez-Nelson, B. Bowler, E. Brownlee, J. K. Ehn, K. E. Frey, R. Garley, S. R. Laney, L. Lubelczyk, J. Mathis, A. Matsuoka, B. G. Mitchell, G. W. K. Moore, E. Ortega-Retuerta, S. Pal, C. M. Polashenski, R. A. Reynolds, B. Scheiber, H. M. Sosik, M. Stephens, J. H. Swift (2012). Massive phytoplankton blooms under Arctic sea ice. Science, 336, 1408.

Arrigo, K. R., D. L. Worthen, A. Schnell, and M. P. Lizotte (1998). Primary production in Southern Ocean waters. Journal of Geophysical Research, 103 (C8), 15,587-15,600.

Arrigo, K. R., G. van Dijken, and S. Pabi (2008b). Impact of a shrinking Arctic ice cover on marine primary production. Geophysical Research Letters, 35, L19603, doi:10.1029/2008GL035028.

Arrigo, K. R., J. N. Kremer, et C. W. Sullivan (1993). A simulated Antarctic fast ice ecosystem. Journal of Geophysical Research, 98 (C4), 6929-6946.

Arrigo, K. R., Mock and M. P. , T., Lizotte, M. (2010). Primary producers and sea ice. In: Sea Ice, Second Edition (eds D. N. Thomas and G. S. Dieckmann), pp. 283-326, WileyBlackwell, Oxford, UK.

Arrigo, K. R., van Dijken, L.G. L., and S. Bushinsky (2008a). Primary production in the Southern Ocean, 1997-2006. Journal of Geophysical Research, 113, C08004, doi: 10.1029/2007JC004551.

Arrigo, K., and C. W. Sullivan (1992). The influence of salinity and temperature covariation on the photophysiological characteristics of Antarctic sea ice microalgae. Journal of Phycology, 28, 746-756.

Arrigo, K., D. L. Worthen, M. P. Lizotte, P. Dixon, et G. Dieckmann (1997). Primary production in Antarctic sea ice. Science, 276, 394-397.

Arzel, O., Fichefet, T., and Goosse, H. (2006). Sea ice evolution over the 20th and 21st centuries as simulated by current AOGCMs. Ocean Modelling, 12, 401- 415.

Assur, A. (1958). Composition of sea ice and its tensile strength. In: Arctic sea ice; conference held at Easton, Maryland, February 24- 27, 1958, Vol. 598 of Publs. Natl. Res. Coun. Wash./, 106-138, Washington, DC, US.

Aumont, O., E. Maier-Reimer, S. Blain, and P. Monfray (2003). An ecosystem model of the global ocean including Fe, Si, P colimitations. Global Biogeochemical Cycles, 17(2), 1060, doi:10.1029/2001GB001745.

Bates, N. R., S. B. Moran, D. A. Hansell, and J. T. Mathis (2006). An increasing $\mathrm{CO}_{2}$ sink in the Arctic Ocean due to sea-ice loss. Geophysical Research Letters, 33, L23609, doi:10.1029/2006GL027028.

Becquevort, S., Dumont, I., Tison, J.-L., Lannuzel, D., Sauvée, M.-L., Chou, L., and V. Schoemann (2009). Biogeochemistry and microbial community composition in sea ice and underlying seawater off East Antarctic during early spring. Polar Biology, 32, 879-895.

Belt, S. T., Massé, G., Rowland, S. J., Poulin, M., Michel, C., and B. LeBlanc. (2007). A novel chemical fossil of palaeo sea ice: IP. Organic Geochemistry, 38, 16-27.

Belzile, C., Johannessen, S. C., Gosselin, M., Demers, S., and W. L. Miller (2000). Ultraviolet attenuation by dissolved and particulate constituents of first-year ice during late spring in an Arctic polynya. Limnology and Oceanography, 45(6), 1265-1273.

Bitz, C. M., M. M. Holland, A. J. Weaver, and M. Eby. Simulating the ice-thickness distribution in a coupled climate model (2001). Journal of Geophysical Research, 106 (C2), 2441-2463.

Bouttes, N., Paillard, D., and Roche, D. M. (2010). Impact of brine-induced stratification on the glacial carbon cycle. Climate of the Past, 6, 575-589, doi:10.5194/cp-6-575-2010.

Bowling, D. R., and W. J. Massman (2011). Persistent windinduced enhancement of diffusive $\mathrm{CO}$ transport in a mountain forest snowpack. Journal of Geophysical Research, 116, G04006, doi:10.1029/2011JG001722.

Boyd, P. W., and M. J. Ellwood (2010). The biogeochemical cycle of iron in the ocean. Nature Geoscience, 3, 675-682.

Boye, M., van den Berg, C. M. G., De Jong, J. T. M., Leach, H., Croot, P., and H. J. W. de Baar (2001). Organic complexation of iron in the Southern Ocean. Deep-Sea Research I, 48(6), 1477-1497.

Brabant, F., S. El Amri, and J.-L. Tison (2011). A robust approach for the determination of dimethylsulfoxide in sea ice. Limnology and Oceanography, 9, 261-274, doi: 10.4319/lom.2011.9.261.

Charlson, R. J., J. E. Lovelock, M. O. Andreae, et S. G. Warren (1987). Oceanic phytoplankton, atmospheric sulphur, cloud albedo and climate. Nature, 326, 655-661.

Comiso, J. C. (2010). Variability and Trends of the Global Sea Ice Cover. In: Sea Ice, Second Edition (eds D. N. Thomas and G. S. Dieckmann), pp. 205-246, WileyBlackwell, Oxford, UK.

Constable, A. J., S. Nicol, and P. G. Strutton (2003). Southern Ocean productivity in relation to spatial and temporal variation in the physical environment. Journal of Geophysical Research, 108, 8079, doi:10.1029/2001JC001270.

Cota, G. F., and E. P. W. Horne (1989). Physical control of Arctic ice algal production. Marine Ecology Progress Series, 52, 111-121. 
Cota, G. F., S. J. Prisenberg, E. B. Bennett, J. W. Loder, M. R. Lewis, J. L. Anning, N. H. F. Watson, and L. R. Harris (1987). Nutrient fluxes during extended blooms of Arctic ice algae. Journal of Geophysical Research (C2), 92, 1951-1962.

Cox, G. F. N. and Weeks, W. F. (1983). Equations for determining the gas and brine volumes in sea-ice samples. Journal of Glaciology, 29, 306-316.

Crosta X., Denis, D., and O. Ther (2008). Sea ice seasonality during the Holocene, Adélie Land, East Antarctica. Marine Micropaleontology, 66 (3-4), 222-232.

Crosta, X., Pichon, J.-J. and L. H. Burckle (1998). Application of modern analog technique to marine Antarctic diatoms: reconstruction of maximum sea ice extent at the Last Glacial Maximum. Paleoceanography, 13(3), 2846-297.

Curran, M. A. J., T. D. van Ommen, V. I. Morgan, K. L. Phillips, and A. S. Palmer (2003). Ice core evidence for Antarctic sea ice decline since the 1950s. Science, 14302, 1203-1206.

Curran, M.A.J., and G.B. Jones (2000). Dimethylsulfide in the Southern Ocean: seasonality and flux. Journal of Geophysical Research, 105 (D16), 20,451-20,459.

Damm, E., E. Helmke, S. Thoms, U. Schauer, E. Nöthig, K. Bakker, and R. P. Kiene (2010). Methane production in aerobic oligotrophic surface water in the central Arctic Ocean. Biogeosciences, 7(3), 1099-1108.

de Baar, H. J. W. (1994). von Liebig's Law of the Minimum and Plankton Ecology (1899-1991). Progress in Oceanography, 33, 347-386.

de Vernal, A. , Eynaud, F. , Henry, M. , Hillaire-Marcel, C. , Londeix, L. , Mangin, S. , Matthiessen, J. , Marret, F. , Radi, T. and Rochon, A., Solignac, S. and J.-L. Turon (2005). Reconstruction of sea-surface conditions at middle to high latitudes of the Northern Hemisphere during the Last Glacial Maximum (LGM) based on dinoflagellate cyst assemblages. Quaternary Science Reviews, 24 , 897-924 . doi: 10.1016/j.quascirev.2004.06.014.

Deal, C., M. Jin, S. Elliott, E. Hunke, M. Maltrud, and N. Jeffery (2011). Large-scale modeling of primary production and ice algal biomass within Arctic sea ice in 1992. Journal of Geophysical Research, 116, C07004, doi:10.1029/2010JC006409.

DeGrandpre, M. D., A. Vodacek, R. K. Nelson, E. J. Bruce, and N. V. Blough (1996). Seasonal seawater optical properties of the U.S. Middle Atlantic Bight. Journal of Geophysical Research, 101(C10), 22,727-22,736, doi:10.1029/96JC01572.

Delille, B. (2006). Inorganic carbon dynamics and air-ice-sea $\mathrm{CO}$ fluxes in the open and coastal waters of the Southern Ocean, 297 pp, Phd. Thesis, University of Liège, Belgium.

Delille, B., Jourdain, B., Borges, A.V., Tison J.L., and D. Delille (2007). Biogas ( $\mathrm{CO}_{2}, \mathrm{O}$, dimethylsulfide) dynamics in spring Antarctic fast ice. Limnology and Oceanography, 52, 1367-1379.
Deming, J.W. (2010). Sea ice bacteria and viruses. In: Sea Ice, Second Edition (eds D. N. Thomas and G. S. Dieckmann), pp. 247-282, Wiley-Blackwell, Oxford, UK.

Deser, C., and H. Teng (2008). Recent trends in Arctic sea ice and the evolving role of atmospheric circulation forcing, 1979-2007. Arctic Sea Ice Decline: Observations, Projections, Mechanisms, and Implications, AGU Monographs, 180, (ed. E. T. DeWeaver, C. M. Bitz, and L. B. Tremblay), 7-26.

Dieckmann, G. S., and H. H. Hellmer (2010). The importance of Sea Ice: an overview. In: Sea Ice, Second Edition (eds D. N. Thomas and G. S. Dieckmann), pp. 1-22, WileyBlackwell, Oxford, UK.

Dieckmann, G. S., G. Nehrke, S. Papadimitriou, J. Göttlicher, R. Steininger, H. Kennedy, D. Wolf-Gladrow, and D. N. Thomas (2008). Calcium carbonate as ikaite crystals in Antarctic sea ice. Geophysical Research Letters, 35, L08501, doi:10.1029/2008GL033540.

Dieckmann, G. S., M. A. Lange, S. F. Ackley, and J. C. Jennings Jr. (1991). The nutrient status in sea ice of the Weddell Sea during winter: Effects of sea ice texture and algae. Polar Biology, 11, 449-456.

Dieckmann, G.S., $\quad$ Nehrke, G., Uhlig, C., Göttlicher, J., Gerland, S., Granskog, M. A., and Thomas, D. N. (2010). Brief Communication: Ikaite $(\mathrm{CaCO} \cdot 6 \mathrm{HO})$ discovered in Arctic sea ice. The Cryosphere, 4, 227-230, doi:10.5194/tc4-227-2010.

DiTullio, G.R., D.L. Garrison, and S. Mathot (1998). Dimethylsulfoniopropionate in sea ice algae from the Ross Sea polynia, in Antarctic Sea Ice: biological processes, interaction and variability, Antarctic Research Series, 73, edited by M. P. Lizotte and K. R. Arrigo, 139-146, American Geophysical Union, Washington D.C.

Domine, F., A. S. Taillandier, W. R. Simpson, and K. Severin (2005). Specific surface area, density and microstructure of frost flowers. Geophysical Research Letters, 32, L13502, doi:10.1029/2005GL023245.

Doney, S. C., W. M. Balch, V. J. Fabry, et R. A. Feely (2009). Ocean acidification : a critical emerging problem for the ocean sciences. Oceanography, 22 (4), 16-25.

Douglas, T. A., et al. (2012). Frost flowers growing in the Arctic ocean-atmosphere-sea ice-snow interface: 1. Chemical composition, Journal of Geophysical Research, 117, D00R09, doi:10.1029/2011JD016460.

Ehn, J., Granskog, M.A, Reinart, A., Erm, A. (2004). Optical properties of melting landfast sea ice and underlying seawater in Santala Bay, Gulf of Finland. Journal of Geophysical Research, 109, C09003, doi:10.1029/2003JC002042.

Eicken, H. (1992). Salinity profiles of Antarctic sea ice: Field data and model results. Journal of Geophysical Research, 97 (C10), 15,545-15,557. 
Eicken, H. (1998). Factors determining microstructure, salinity and stable-isotope composition of Antarctic sea ice: Deriving modes and rates of ice growth in the Weddell Sea. In Antarctic Sea Ice: Physical Processes, Interactions and Variability, Antarctic Research Series, vol. 74, edited by M. O. Jeffries, pp. 89-122.

Eisenman, I. (2010). Geographic muting of changes in the Arctic sea ice cover, Geophysical Research Letters, 37, L16501, doi:10.1029/2010GL043741.

Else, B. G. T., T. N. Papakyriakou, M. A. Granskog, and J. J. Yackel (2008). Observations of sea surface $f \mathrm{CO}_{2}$ distributions and estimated air-sea $\mathrm{CO}$ fluxes in the Hudson Bay region (Canada) during the open water season. Journal of Geophysical Research, 113, C08026, doi:10.1029/2007JC004389.

Else, B. G. T., T. N. Papakyriakou, R. J. Galley, W. M. Drennan, L. A. Miller, and H. Thomas, (2011). Wintertime CO fluxes in an Arctic polynya using eddy covariance: Evidence for enhanced air-sea gas transfer during ice formation. Journal of Geophysical Research, 116, C00G03, doi:10.1029/2010JC006760.

Emery, W. J., C. W. Fowler, and J. A. Maslanik (1997). Satellite-derived maps of Arctic and Antarctic sea ice motion: 1988 to 1994. Geophysical Research Letters, 24(8), 897-900, doi:10.1029/97GL00755.

Fischer, M., D. N. Thomas, A. Krell, G. Nehrke, J. Göttlicher, L. Norman, K. M. Meiners, C. Riaux-Gobin and G. S. Dieckmann (2012). Quantification of ikaite in Antarctic sea ice. Antarctic Science, pp 1-12, doi:10.1017/S0954102012001150.

Flores, H. and 29 others (2012). Impact of climate change on Antarctic krill. Marine Ecology Progress Series, 458, 1-19.

Fortier, M., Fortier, L., Michel, C., and L. Legendre (2002). Climatic and biological forcing of the vertical flux of biogenic particles under seasonal Arctic sea ice. Marine Ecology Progress Series, 225, 1-16.

Frey, K. E., D. K. Perovich, and B. Light (2011). The spatial distribution of solar radiation under a melting Arctic sea ice cover. Geophysical Research Letters, 38, L22501, doi:10.1029/2011GL049421.

Friedlingstein, P., P. Cox, R. Betts, L. Bopp, W. von Bloh, V. Brovkin, P. Cadule, S. Doney, M. Eby, I. Fung, G. Bala, J. John, C. Jones, F. Joos, T. Kato, M. Kawamiya, W. Knorr, K. Lindsay, H. D. Matthews, T. Raddatz, P. Rayner, C. Reick, E. Roeckner, K.-G. Schnitzler, R. Schnur, K. Strassmann, A. J. Weaver, C. Yoshikawa, et N. Zeng (2006). Climate-Carbon Cycle Feedback Analysis : Results from the CMIP Model Intercomparison. Journal of Climate, 19(14), 3337-3353.

Fritsen, C. H., J. Memmott, and F. J. Stewart (2008). Interannual sea-ice dynamics and micro-algal biomass in winter pack ice of Marguerite Bay, Antarctica. Deep-Sea Research II, 55, 2059-2067.
Fritsen, C. H., V. I. Lytle, S. F. Ackley, and C. W. Sullivan (1994). Autumn bloom of Antarctic pack-ice algae. Science, 266, 782-784.

Gambaro, A., I. Moret, R. Piazza, C. Andreoli, E. D. Rin, G. Capodaglio, C. Barbante, and P. Cescon (2004). Temporal evolution of DMS and DMSP in Antarctic Coastal Sea water. International Journal of Environmental Analytical Chemistry, 84:6-7, 401-412.

Garcia, H. E., R. A. Locarnini, T. P. Boyer, and J. I. Antonov (2006). World Ocean Atlas 2005, vol. 4, Nutrients (Phosphate, Nitrate, Silicate), NOAA Atlas NESDIS 64, edited by S. Levitus, 396 pp., U.S. Gov. Print. Off., Washington, D. C.

Garrison, D.L., S. F. Ackley, and K. R. Buck (1983). A physical mechanism for establishing algal populations in frazil ice. Nature, 306, 363-365, doi:10.1038/306363a0.

Geilfus, N. X. (2011). Inorganic carbon dynamics in coastal arctic sea ice and related air-ice $\mathrm{CO}$ exchanges. Phd Thesis, Université de Liège, Belgium, 189 pp.

Geilfus, N.-X., G. Carnat, G. S. Dieckmann, N. Halden, G. Nehrke, T. Papakyriakou, J.-L. Tison and B. Delille (in press). First estimates of the contribution of $\mathrm{CaCO} 3$ precipitation to the release of $\mathrm{CO}$ to the atmosphere during young sea ice growth. Journal of Geophysical Research.

Geilfus, N.-X., G. Carnat, T. Papakyriakou, J.-L. Tison, B. Else, H. Thomas, E. Shadwick, and B. Delille (2012)., Dynamics of $\mathrm{pCO}$ and related air-ice $\mathrm{CO}$ fluxes in the Arctic coastal zone (Amundsen Gulf, Beaufort Sea). Journal of Geophysical Research, 117, C00G10, doi:10.1029/2011JC007118.

Giannelli, V., D. N. Thomas, C. Haas, G. Kattner, H. Kennedy, and G. S. Dieckmann (2001), Behaviour of dissolved organic matter and inorganic nutrients during experimental sea-ice formation. Annals of Glaciology, 33, 317-321.

Gleitz, M., Loeff, M. R. V. D., Thomas, D. N., Dieckmann, G. S., and F. J. Millero (1995). Comparison of summer and winter inorganic carbon, oxygen and nutrient concentrations in Antarctic sea ice brine. Marine Chemistry, 51, 81-91.

Gloersen, P., W. J. Campbell, D. J. Cavalieri, J.C. Comiso, C. L. Parkinson, and H. J. Zwally (1993). Satellite passive microwave observations and analysis of Arctic and Antarctic sea ice, 1978-1987. Annals of Glaciology, 17, 149-154.

Glud, R.N., Rysgaard, S., and M. Kühl (2002). A laboratory study on $\mathrm{O}$ dynamics and photosynthesis in ice algal communities: quantification by microsensors, $\mathrm{O}$ exchange rates, $\mathrm{C}$ incubations and a PAM fluorometer. Aquatic Microbial Ecology, 27, 301-311.

Golden, K.M., Ackley, S.F., Lytle, V.I. (1998). The percolation phase transition in sea ice. Science, 282, 2238-2241.

Gosselin, M., Legendre, L., Therriault, J.-C., Demers, S., and M. Rochet (1986). Physical control of the horizontal 
patchiness of sea-ice microalgae. Marine Ecology Progress Series, 29, 289-298.

Gradinger, R. (2009). Sea ice algae: Major contributors to primary production and algal biomass in the Chukchi and Beaufort sea during May/June 2002. Deep-Sea Research II, 56, 1201-1212.

Gradinger, R. R., Kaufman, M.R., and B. A. Bluhm (2009). Pivotal role of sea ice sediments in the seasonal development of near-shore Arctic fast ice biota. Marine Ecology Progress Series 394, 49-63.

Grebmeier, J. M., J. E. Overland, S. E. Moore, E. V. Farley, E. C. Carmack, L. W. Cooper, K. E. Frey, J. H. Helle, F. A. McLaughlin, et S. L. McNutt (2006). A major ecosystem shift in the Northern Bering Sea. Science, 311, 1461-1464, doi: 10.1126/science. 1121365 .

Gruber, N., M. Gloor, S. E. M. Fletcher, S. C. Doney, S. Dutkiewicz, M. J. Follows, M. Gerber, A. R. Jacobson, F. Joos, K. Lindsay, D. Menemenlis, A. Muouchet, S. A. Müller, J. L. Sarmiento, et T. Takahashi (2009). Oceanic sources, sinks, and transport of atmospheric $\mathrm{CO}_{\text {. }}$ Global Biogeochemical Cycles, 23, GB1005, doi: 10.1029/2008GB003349.

Günther, S., and G. S. Dieckmann (1999). Seasonal development of algal biomass in snow-covered fast ice and the underlying platelet layer in the Weddell Sea, Antarctica. Antarctic Science, 11, 305-315, doi:10.1017/S0954102099000395.

Haas, C., D. N. Thomas, D. N. and J. Bareiss, (2001). Surface properties and processes of perennial Antarctic sea ice in summer. Journal of Glaciology, 47, 613-625.

Hamre, B., J.-G. Winther, S. Gerland, J. J. Stamnes, and K. Stamnes (2004). Modeled and measured optical transmittance of snow-covered first-year sea ice in Kongsfjorden, Svalbard. Journal of Geophysical Research, 109, C10006, doi:10.1029/2003JC001926.

Hassler, C. S., and V. Schoemann, (2009). Bioavailability of organically bound $\mathrm{Fe}$ to model phytoplankton of the Southern Ocean. Biogeosciences, 6, 2281-2296.

Heil, P., C. Fowler, C. W. and S. E. Lake (2006). Antarctic sea-ice velocity as derived from SSM/I imagery. Annals of Glaciology, 44, 361-366.

Heinesch, B., M. Yernaux, M. Aubinet, N.-X. Geilfus, T. Papakyriakou, G. Carnat, H. Eicken, J.- L. Tison, and B. Delille (2009). Measuring air-ice $C O$ fluxes in the Arctic. FluxLetter: The Newsletter of FLUXNET, 2(2), 9-10.

Herborg, L.-M., Thomas, D. N., Kennedy, H., Haas, C., and G. S. Dieckmann (2001) Dissolved carbohydrates in Antarctic sea ice. Antarctic Science, 13, 119-125 doi:10.1017/S0954102001000190.

Hezel, P. J., B. Alexander, C. M. Bitz, E. J. Steig, C. D. Holmes, X. Yang, and J. Sciare (2011), Modeled methanesulfonic acid (MSA) deposition in Antarctica and its relationship to sea ice. Journal of Geophysical Research, 116, D23214, doi:10.1029/2011JD016383.

Holland, M. M., C. M. Bitz, and B. Tremblay (2006), Future abrupt reductions in the summer Arctic sea ice. Geophysical Research Letters, 33, L23503, doi:10.1029/2006GL028024.

Holland, M.M. and C.M. Bitz, (2003). Polar amplification of climate change in coupled models. Climate Dynamics, 21, 221-232, doi:00382-003-0332-6.

Holland, P., and R. Kwok (2012). Wind-driven trends in Antarctic sea-ice drift. Nature Geoscience, 5, 872-875.

Horner R., Ackley, S.F., Dieckmann G.S., Gulliksen B., Hoshiai T., Legendre L, Melnikov I.A., Reeburgh W.S., Spindler M, Sullivan C.W. (1992). Ecology of sea ice biota: 1. Habitat, terminology, and methodology. Polar Biology 12 (3-4), 417-427, doi: 10.1007/BF00243113.

Horner, R. A. (1985). Sea Ice Biota. CRC Press, Boca Raton, FL (USA), 215pp.

Hunke, E. C., and W. H. Lipscomb (2010). CICE: The Llos Aalamos sea ice model documentation and software user's manual, Version 4.1. Technical report, Los Alamos National Laboratory, 2010.

Hunke, E. C., Notz, D., Turner, A. K., and M. Vancoppenolle (2011). The multiphase physics of sea ice: a review for model developers. The Cryosphere, 5, 989-1009.

lizuka, Y., Hondoh, T., and Y. Fujii (2008). Antarctic sea ice extent during the Holocene reconstructed from inland ice core evidence. Journal of Geophysical Research, 113, D15114. doi:10.1029/2007JD009326.

Jardon, F., F. Vivier, M. Vancoppenolle, A. Lourenco, P. Bouruet-Aubertot, and Y. Cuypers (2013). Full-depth desalination of warm sea ice. Journal of Geophysical Research, doi:10.1029/2012JC007962, in press.

Järvinen, O., and M. Leppäranta (2011). Transmission of solar radiation through the snow cover on floating ice. Journal of Glaciology, 57 (205), 861-870.

Jeffery, N., E. C. Hunke, and S. M. Elliott (2011). Modeling the transport of passive tracers in sea ice. Journal of Geophysical Research, 116, C07020, doi:10.1029/2010JC006527.

Jeffries, M. O., A. P. Worby, K. Morris, and W. F. Weeks (1997). Seasonal variations in the properties and structural composition of sea ice and snow cover in the Bellingshausen and Amundsen Seas, Antarctica. Journal of Glaciology, 43, 138-151.

Jin, M., C. Deal, S. H. Lee, S. Elliott, E. Hunke, M. Maltrud and N. Jeffery (20121). Investigation of Arctic sea ice ocean primary production for the period 1992-2007 using a 3-D global ice-ocean ecosystem model. Deep-Sea Research II, 81-84, 28-35, doi: 10.1016/j.dsr2.2011.06.003.

Jin, M., C. J. Deal, J. Wang, K.-H. Shin, N. Tanaka, T. E. Whitledge, S. H. LKee, et R. R. Gradinger (2006). Controls of the landfast ice-ocean ecosystem offshore Barrow, Alaska. Annals of Glaciology, 44, 63-72. 
Johnson, K. S. (2001). Iron supply and demand to the upper ocean: lis extraterrestrial dust a significant source of bioavailable iron? Global Biogeochemical Cycles, 15 (1), 6163.

Jones, A. E., P. S. Anderson, E. W. Wolff, J. Turner, A. M. Rankin, and S. R. Colwell (2006). A role for newly forming sea ice in springtime polar tropospheric ozone loss? Observational evidence from Halley station, Antarctica. Journal of Geophysical Research, 111, D08306, doi:10.1029/2005JD006566.

Juhl A. R., Krembs, C., and K. M. Meiners (2011). Seasonal development and discontinuous export of ice algae and other organic fractions from Arctic sea ice. Marine Ecology Progress Series, 436, 1-16.

Kaartokallio, H. (2001), Evidence for active microbial nitrogen transformations in sea ice (Gulf of Bothnia, Baltic Sea) in midwinter. Polar Biology, 24(1), 21-28.

Kaleschke, L., et al. (2004). Frost flowers on sea ice as a source of sea salt and their influence on tropospheric halogen chemistry. Geophysical Research Letters, 31, L16114, doi:10.1029/2004GL020655.

Karl, D. M., L. Beversdorf, K. M. Björkman, M. J. Church, A. Martinez, and E. F. DeLong (2008). Aerobic production of methane in the sea. Nature Geoscience, 1, 473-478.

Kennedy, H., Thomas, D.N., Kattner, G., Haas, C., Dieckmann, G.S. (2002). Particulate organic matter in Antarctic summer sea ice: concentration and stable isotopic composition. Marine Ecology Progress Series, 238, 1-13.

Killawee J.A., Fairchild, I.J., Tison, J.-L., Janssens, L., and R. Lorrain (1998). Segregation of solutes and gases in experimental freezing of dilute solutions: Implications for natural glacial systems. Geochimica et Cosmochimica Acta, $62,3637-3655$

Kirst, G.O., C. Thiel, H. Wolff, J. Nothnagel, M. Wanzek, and R. Ulmke (1991). Dimethylsulphoniopropionate (DMSP) in ice algae and its possible biological role. Marine Chemistry, 35, 381-388.

Kort, E. A., et al. (2012), Atmospheric observations of Arctic Ocean methane emissions up to $82^{\circ}$ north. Nature Geoscience, 5(5), 318-321.

Krembs, C., Eicken, H., and J. W. Deming (2011). Exopolymer alteration of physical properties of sea ice and implications for ice habitability and biogeochemistry in a warmer Arctic. PNAS, 108, 3653-3658.

Krembs, C., Eicken, H., Junge, K., and J. W. Deming (2002a). High concentrations of exopolymeric substances in Arctic winter sea ice: implications for the polar ocean carbon cycle and cryoprotection of diatoms. Deep-Sea Research I, $49,2163-2181$.

Krembs, C., Gradinger, R., and M. Spindler (2000). Implications of brine channel geometry and surface area for the interaction of sympagic organisms in Arctic sea ice.
Journal of Experimental Marine Biology and Ecology, 243, 55-80.

Krembs, C., Mock, T., and R. Gradinger (2001). A mesocosm study of physical-biological interactions in artificial sea ice: effects of brine channel surface evolution and brine movement on algal biomass. Polar Biology, 24, 356-364.

Kristiansen, S., Farbrot, T., Kuosa, H., Myklestad, S. M., and C. H. von Quillfeldt (1998). Nitrogen uptake in the filtration community, an ice algal community in Antarctic pack ice. Polar Biology, 19, 307-315.

Kwok, R., and D. A. Rothrock (2009). Decline in Arctic sea ice thickness from submarine and ICESat records: $1958-$ 2008. Geophysical Research Letters, 36, L15501, doi:10.1029/2009GL039035.

Kwok, R., J. C. Curlander, R. McConnell, and S. S. Pang (1990). An ice-motion tracking system at the Alaska SAR Facility. IEEE Journal of Oceanic Engineering, 15, 44-54.

Lancelot C., A. de Montety, H. Goosse, S. Becquevort, V Schoemann, B. Pasquer and M. Vancoppenolle (2009). Spatial distribution of the iron supply to phytoplankton in the Southern Ocean: a model study. Biogeosciences, 6, 28612878.

Lange, M. A., S. F. Ackley, P. Wadhams, G. S. Dieckmann, and H. Eicken (1989). Devel- opment of sea ice in the Weddell Sea. Annals of Glaciology, 12, 92-96.

Lannuzel D., Schoemann V., de Jong, J., Pasquer, B., van der Merwe, P., and A. Bowie A.R. (2010). Distribution of dissolved iron in Antarctic sea ice: Spatial, seasonal and inter-annual variability. Journal of Geophysical Research, 115, G03022, doi:10.1029/2009JG001031.

Lannuzel, D., Bowie, A. R., van der Merwe, P. C., Townsend, A. T., \& Schoemann, V. (2011). Distribution of dissolved and particulate metals in Antarctic sea ice. Marine Chemistry, 124(1-4), 134-146.

Lannuzel, D., Schoemann, V., de Jong, J. T. M., Tison, J.-L., and L.\& Chou, L. (2007). Distribution and biogeochemical behaviour of iron in the East Antarctic sea-ice. Marine Chemistry, 106, 18-32.

Lavoie, D., K. Denman, and C. Michel (2005). Modeling ice algal growth and decline in a seasonally ice-covered region of the Arctic (Resolute Passage, Canadian Aarchipelago). Journal of Geophysical Research, 110, C11009, doi:10.1029/2005JC002922.

Lavoie, D., R. W. Macdonald, and K. L. Denman (2009). Primary productivity and export fluxes on the Canadian shelf of the Beaufort Sea: A modelling study, Journal of Marine Systems, 75, 17-32.

Lee, P.A., S.J. de Mora, M. Gosselin, M. Levasseur, R.-C. Bouillon, C. Nozais, and C. Michel [2001]. Particulate dimethylsulfoxide in Arctic sea-ice algal communities: the cryoprotectant hypothesis revisited. Journal of Phycology, 37, 488-499. 
Lee, S. H., D. A. Stockwell, H.-M. Joo, Y. B. Son, C.-K. Kang, and T. E. Whitledge (2012). Phytoplankton production from melting ponds on Arctic sea ice. Journal of Geophysical Research, 117, C04030, doi:10.1029/2011JC007717.

Leonard, K.C., and T. Maksym (2011). The importance of wind-blown snow rdistribution to snow accumulation on Bellingshausen sea ice. Annals of Glaciology, 52(57), 271278 .

Levasseur, M., M. Gosselin, and S. Michaud (1994). A new source of dimethylsulfide (DMS) for the Arctic atmosphere: ice diatoms. Marine Biology, 121, 381-387

Lewis, M. J., Tison, J.-L., Weissling, B., Delille, B., Ackley, S. F., Brabant, F., and H. Xie (2011). Sea ice and snow cover characteristics during the winter-spring transition in the Bellingshausen Sea: An overview of SIMBA 2007. Deep-Sea Research II, 58, 1019-1038.

Light, B., Eicken, H., Maykut, G. A., and T. C. Grenfell (1998). The effect of included particulates on the spectral albedo of sea ice. Journal of Geophysical Research, 103 (C12), 27739-27752.

Light, B., G. A. Maykut, and T. C. Grenfell (2003). Effects of temperature on the microstructure of first-year Arctic sea ice. Journal of Geophysical Research, 108(C2), 3051, doi:10.1029/2001JC000887.

Light, B., T. C. Grenfell, and D. K. Perovich (2008). Transmission and absorption of solar radiation by Arctic sea ice during the melt season. Journal of Geophysical Research, 113, C03023, doi:10.1029/2006JC003977.

Lizotte, M.P. (2001). The contributions of sea ice algae to Antarctic marine primary production. American Zoologist, 41(1), 57-73. doi: 10.1093/icb/41.1.57.

Loose, B., and P. Schlosser (2011). Sea ice and its effect on CO flux between the atmosphere and the Southern Ocean interior. Journal of Geophysical Research, 116, C11019, doi:10.1029/2010JC006509.

Loose, B., Miller, L.A., Elliott, S., and T. Papakyriakou (2011). Sea ice biogeochemistry and material transport across the frozen interface. Oceanography, 24, 202-218.

Loose, B., W. R. McGillis, P. Schlosser, D. Perovich, and T. Takahashi (2009). Effects of freezing, growth, and ice cover on gas transport processes in laboratory seawater experiments. Geophysical Research Letters, 36, L05603, doi:10.1029/2008GL036318.

Madec, G., and the NEMO team (2008). NEMO ocean engine. Note du Pôle de modélisation No 27 ISSN No 12881619, Institut Pierre-Simon Laplace (IPSL), France.

Maksym, T. and M. O. Jeffries (2000). A one-dimensional percolation model of flooding and snow ice formation on Antarctic sea ice. Journal of Geophysical Research, 105 (C11), 26,313-26,33126.

Maksym, T., and T. Markus (2008). Antarctic sea ice thickness and snow-to-ice conversion from atmospheric reanalysis and passive microwave snow depth. Journal of Geophysical Research, 113, C02S12, doi:10.1029/2006JC004085.

Maksym, T., S. E. Stammerjohn, S. E., S. F. Ackley, and R. Massom (2012). Antarctic Sea Ice - A Polar Opposite? Oceanography, 25(3), 140-151, http://dx.doi.org/10.5670/oceanog.2012.88.

Mårtensson, S., H. E. M. Meier, P. Pemberton, and J. Haapala (2012), Ridged sea ice characteristics in the Arctic from a coupled multicategory sea ice model. Journal of Geophysical Research, 117, C00D15, doi:10.1029/2010JC006936.

Martin, J. H., Gordon, R. M., \& Fitzwater, S. E. (1991). The case for iron. Limnology and Oceanography, 36(8), 17931802.

Martin, S. (1981). Frazil ice in rivers and oceans. Annual Review of Fluid Mechanics, 13, 379-397.

Massom, R. A., Eicken, H., Haas, C., Jeffries, M. O., Drinkwater, M. R., Sturm, M., Worby, A. P., Wu, X., Lytle, V. I., Ushio, S., Morris, K., Reid, P. A., Warren, S. G., and Allison, I. (2001). Snow on Antarctic sea ice. Reviews of Geophysics, 39, 413-445.

Massonnet, F., Fichefet, T., Goosse, H., Bitz, C.M., Philippon-Berthier, G., Holland, M.M., and Barriat, P.-Y. (2012). Constraining projections of summer Arctic sea ice. The Cryosphere, 6, 1383-1394.

Massonnet, F., Mathiot, P., Fichefet, T., Goosse, H., KönigBeatty, C., Vancoppenolle, M. and T. Lavergne (in revision). A model reconstruction of the Antarctic sea ice thickness and volume changes over 1980-2008 using data assimilation. Ocean Modelling.

Matsuo, S., and Miyake, Y. (1966). Gas composition in ice samples from Antarctica. Journal of Geophysical Research, $71,5235-5241$.

Maykut, G. A., and N. Untersteiner (1971). Some results from a time-dependent thermodynamic model of sea ice. Journal of Geophysical Research, 76, 1550-1575.

McMinn, A., Skerratt, J., Trull, T., Ashworth, C., Lizotte, M. (1999). Nutrient stress gradient in the bottom $5 \mathrm{~cm}$ of fast ice, McMurdo Sound, Antarctica. Polar Biology, 21, 220227.

McPhee, M. G. (2008). Physics of early summer ice/ocean exchange in the western western Weddell Sea during ISPOL. Deep-Sea Research II, 55, 1075-1097.

Meiners, K. M., L. Norman, M. A. Granskog, A. Krell, P. Heil, and D. N. Thomas (2011). Physico-ecobiogeochemistry of East Antarctic pack ice during the winter-spring transition. Deep-Sea-Research II, 58, 1172-1181.

Meiners, K. M., Vancoppenolle, M., Thanassekos, S., Dieckmann, G.S., Thomas, D.N., Tison, J.-L., Arrigo A.R., Garrison, D., McMinn, A., Lannuzel, D., van der Merwe, P., Swadling, K., Smith Jr., W.O., Melnikov, I., Raymond, B., Chlorophyll $a$ in Antarctic sea ice from historical ice core 
data. Geophysical Research Letters, 39, L21602, doi:10.1029/2012GL053478.

Meiners, K. M., Brinkmeyer, R., Granskog, M. A., and A. Lindfors (2004). Abundance, size distribution and bacterial colonization of exopolymer particles in Antarctic sea ice (Bellingshausen Sea). Aquatic Microbial Ecology, 35, 283296.

Meiners, K., Gradinger, R., Fehling, J., Civitarese, G., and M. Spindler (2003). Vertical distribution of exoploymer particles in sea ice of the Fram Strait (Arctic) during autumn. Marine Ecology Progress Series, 248, 1-13.

Meiners, K. M., Krembs, C. and R. Gradinger (2008). Exopolymer particles: microbial hotspots of enhanced bacterial activity in Arctic fast ice (Chukchi Sea)., Aquatic Microbial Ecology, 52, 195-207.

Michel, C., Ingram, R. G., and L. R. Harris (2006). Variability in oceanographic and ecological processes in the Canadian Arctic Archipelago. Progress in Oceanography, 712, 379401.

Michel, C., Legendre, L., Therriault, J.-C., Demers, S., and T. Vandevelde (1993). Springtime coupling between ice algal and phytoplankton assemblages in Southeastern Hudson Bay, Canadian Arctic. Polar Biology, 13, 441-449.

Michel, C., Legendre, L., Ingram, R. G., Gosselin, M., and M. Levasseur (1996). Carbon budget of sea-ice algae under first-year ice in spring: evidence of a significant transfer to zooplanton grazers. Journal of Geophysical Research, 101 (C8), 18,345-18,360.

Michel, C., Nielsen, T. G., Nozais, C. and M. Gosselin (2002). Significance of sedimentation and grazing by ice micro-and meiofauna for carbon cycling in annual sea ice (northern Baffin Bay). Aquatic Microbial Ecology, 30, 57-68.

Miller, L. A., G. Carnat, B. G. T. Else, N. Sutherland, and T. N. Papakyriakou (2011a). Carbonate system evolution at the Arctic Ocean surface during autumn freeze-up. Journal of Geophysical Research, 116, C00G04, doi:10.1029/2011JC007143.

Miller, L. A., T. N. Papakyriakou, R. E. Collins, J. W. Deming, J. K. Ehn, R. W. Macdonald, A. Mucci, O. Owens, M. Raudsepp, and N. Sutherland (2011b). Carbon dynamics in sea ice: A winter flux time series. Journal of Geophysical Research, 116, C02028, doi:10.1029/2009JC006058.

Mock, T., and R. Gradinger (2000). Changes in photosynthetic carbon allocation in algal assemblages of Arctic sea ice with decreasing nutrient concentrations and irradiance. Marine Ecology Progress Series, 202, 1-11.

Monod, J. (1949). The growth of bacterial cultures. Annual Review of Microbiology, 3, 371-394.

Montes-Hugo, M., Doney, C. S. C., Ducklow, W. H. W., Fraser, W., Martinson, D., Stammerjohn, E. S. E., Schofield, O. (2009). Recent changes in phytoplankton communities associated with rapid regional climate change along the Western Antarctic Peninsula. Science, 323, 1470-1473.
Moore, J. K. and O. Braucher (2008). Sedimentary and mineral dust sources of dissolved iron to the world ocean. Biogeosciences, 5, 631-656.

Morales Maqueda, M. A., and S. Rahmstorf (2002). Did Antarctic sea-ice expansion cause glacial $\mathrm{CO}$ decline? Geophysical Research Letters, 29, 1011, doi:10.1029/2001GL013240.

Moreau, S., G. A. Ferreyra, B. Mercier, K. Lemarchand, M. Lionard, S. Roy, B. Mostajir, S. Roy, B. van Hardenberg and S. Demers (2010). Variability of the microbial community in the western Antarctic Peninsula from late fall to spring during a low-ice cover year. Polar Biology, 33(12), 15991614.

Moreau, S., Vancoppenolle, M., Zhou, J., Tison, J.-L., Delille, B., Goosse, H. (in revision). Modeling argon dynamics in first-year sea ice. Ocean Modelling.

Mucci, A., B. Lansard, L. A. Miller, and T. N. Papakyriakou (2010). CO fluxes across the air-sea interface in the southeastern Beaufort Sea: Ice-free period. Journal of Geophysical Research, 115, C04003, doi:10.1029/2009JC005330.

Müller, J., Massé, G., Stein, R. and S. T. Belt (2009). Variability of sea-ice conditions in the Fram Strait over the past 30,000 years. Nature Geoscience, 2, 772-776.

Mundy C.J., Barber, D.G., and C. Michel (2005). Variability of snow and ice thermal, physical and optial properties pertinent to sea ice algae biomass during spring. Journal of Marine Systems, 58, 107-120.

Mundy, C. J., Gosselin, M., Ehn, J., Gratton, Y., Rossnagel, A., Barber, D. G., Martin, J., Tremblay, J.-E., Palmer, M., Arrigo, K. R., Darnis, G., Fortier, L., Else, B., and Papakyriakou, T. (2009). Contribution of under-ice primary production to an ice-edge upwelling phytoplankton bloom in the Canadian Beaufort Sea. Geophysical Research Letters, 36, L17601, doi:10.1029/2009GL038837.

Mundy, C.J., Ehn, J.K., Barber, D.G. and C. Michel (2007). Influence of snow cover and algae on the spectral dependence of transmitted irradiance through Arctic landfast first-year sea ice. Journal of Geophysical Research, 112, C03007, doi: 10.1029/2006JC003683.

Neufeld, J. A. (2008). Natural and forced convection during solidification. Phd Thesis, Yale University, Yale, 186pp.

Nghiem, S. V., et al. (2012). Field and satellite observations of the formation and distribution of Arctic atmospheric bromine above a rejuvenated sea ice cover. Journal of Geophysical Research, 117, D00S05, doi:10.1029/2011JD016268.

Nicolaus, M., C. Haas, and S. Willmes (2009). Evolution of first-year and second-year snow properties on sea ice in the Weddell Sea during spring-summer transition. Journal of Geophysical Research, 114, D17109, doi:10.1029/2008JD011227. 
Nicolaus, M., S. Gerland, S. R. Hudson, S. Hanson, J. Haapala, and D. K. Perovich (2010). Seasonality of spectral albedo and transmittance as observed in the Arctic Transpolar Drift in 2007. Journal of Geophysical Research, 115, C11011, doi:10.1029/2009JC006074.

Nicolaus, M., C. Katlein, J. A. Maslanik, and S. Hendricks (2012). Changes in Arctic sea ice result in increasing light transmittance and absorption. Geophysical Research Letters, doi:10.1029/2012GL053738.

Niedrauer, T. M., and S. Martin (1979). An Experimental Study of Brine Drainage and Convection in Young Sea Ice. Journal of Geophysical Research, 84(C3), 1176-1186.

Niemi, A., Michel, C., and K. Hille and M. Poulin (2011). Protists assemblages in winter sea ice: setting the stage for the spring ice algal bloom. Polar Biology, 34, 1803-1817.

Nomura, D., Eicken, H., Gradinger, R., and K. Shirasawa (2010). Rapid physically driven inversion of the air-sea ice CO flux in the seasonal landfast ice off Barrow, Alaska after onset of surface melt. Continental Shelf Research, 30, 19982004.

Nomura, D., H. Yoshikawa-Inoue, and T. Toyota (2006). The effect of sea-ice growth on air-sea $\mathrm{CO}$ flux in a tank experiment. Tellus, 58B, 418-426.

Nomura, D., McMinn, A., Hattori, H., Aoki, S., Fukuchi, M. (2011). Incorporation of nitrogen compounds into sea ice from atmospheric deposition. Marine Chemistry 127, 90-99.

Nomura, D., S. Koga, N. Kasamatsu, H. Shinagawa, D. Simizu, M. Wada, and M. Fukuchi (2012). Direct measurements of DMS flux from Antarctic fast sea ice to the atmosphere by a chamber technique. Journal of Geophysical Research, 117, C04011, doi: 10.1029/2010JC006755.

Norman, L., Thomas, D. N., Stedmon, C. A., Granskog, M. A., Papadimitriou, S., Krapp, R. H., Meiners, K. M., Lannuzel, D., van der Merwe, P., and G. S. Dieckmann (2011). The characteristics of dissolved organic matter (DOM) and chromophoric dissolved organic matter (CDOM) in Antarctic sea ice. Deep Sea Research Part II, 58 (9), 1075-1091.

Notz, D., and M. G. Worster (2008), In situ measurements of the evolution of young sea ice. Journal of Geophysical Research, 113, C03001, doi:10.1029/2007JC004333.

Notz, D., and M. G. Worster (2009), Desalination processes of sea ice revisited. Journal of Geophysical Research, 114, C05006, doi:10.1029/2008JC004885.

Notz, D., J. S. Wettlaufer, and M. Grae Worster (2005). A non-destructive method for measuring the salinity and solid fraction of growing sea ice in situ, Journal of Glaciology, 51, 159-166.

Palmisano, A. C., Lizotte, M. P., Smith, G. A., Nichols, P. D., White, D. C., Sullivan, C. W. (1988). Changes in photosynthetic carbon assimilation in Antarctic sea-ice diatoms during spring bloom: variation in synthesis of lipid classes. Journal of Experimental Marine Biology and Ecology, 116, 1-13.

Pankowski, A and McMinn, A, (2009). Iron availability regulates growth, photosynthesis, and production of ferredoxin and flavodoxin in Antarctic sea ice diatoms. Aquatic Biology, 4, (3), 273-288.

Papadimitriou, S., Kennedy, H., Kattner, G., Dieckmann, G.S., and D. N. Thomas (2003). Experimental evidence for carbonate precipitation and $\mathrm{CO}_{2}$ degassing during sea ice formation. Geochimica and Cosmochimica Acta, 68, 17491761.

Papadimitriou S., Thomas D.N., Kennedy, H., Haas, C., Kuosa, H., Krell, A., and G. S. Dieckmann (2007). Biogeochemical composition of natural sea ice brines from the Weddell Sea during early austral summer. Limnology and Oceanography, 52, 1809-1823.

Papakyriakou, T., and L. Miller (2011). Springtime CO exchange over seasonal sea ice in the Canadian Arctic Archipelago. Annals of Glaciology, 52, 215-224.

Paterson, H., and J. Laybourn-Parry (2012). Sea Ice microbial dynamics over an annual cycle in Prydz Bay, Antarctica, Polar Biology, 35, 993-1002

Perovich, D. K., and A. J. Gow (1996). A quantitative description of sea ice inclusions. Journal of Geophysical Research, 101(C8), 18,327-18,343, doi:10.1029/96JC01688.

Perovich, D. K., and C. Polashenski (2012). Albedo evolution of seasonal Arctic sea ice. Geophysical Research Letters, 39, L08501, doi:10.1029/2012GL051432.

Perovich, D. K., and J. A. Richter-Menge (1994). Surface characteristics of lead ice. Journal of Geophysical Research, 99 (C8), 16,341-16,350.

Perovich, D. K., B. Light, H. Eicken, K. F. Jones, K. Runciman, and S. V. Nghiem (2007). Increasing solar heating of the Arctic Ocean and adjacent seas, 1979 - 2005: Attribution and role in the ice-albedo feedback. Geophysical Research Letters, 34, L19505, doi:10.1029/2007GL031480.

Perovich, D. K., Grenfell, T.C., Light, B., and P. V. Hobbs (2002a). Seasonal evolution of the albedo of multiyear Arctic sea ice. Journal of Geophysical Research, 107, 8044, doi:10.1029/2000JC000438.

Perovich, D. K., T. C. Grenfell, J. A. Richter-Menge, B. Light, W. B. Tucker III, and H. Eicken (2003). Thin and thinner: Sea ice mass balance measurements during SHEBA. Journal of Geophysical Research, 108, 8050, doi:10.1029/2001JC001079.

Perovich, D. K., Tucker III, W.B., and K. A. Ligett (2002b). Aerial observations of the evolution of ice surface conditions during summer. Journal of Geophysical Research, 107(C10), 8048, doi:10.1029/2000JC000449.

Perrette, M., Yool, A., Quartly, G. D., and E. E. Popova (2011). Near-ubiquity of ice-edge blooms in the Arctic. Biogeosciences, 8, 515-524. 
Petrich, C. and H. Eicken (2010). Growth, structure and properties of sea ice; In: Sea Ice, Second Edition (eds D. N. Thomas and G. S. Dieckmann), pp. 23-78, Wiley-Blackwell, Oxford, UK.

Pogson, L., B. Tremblay, D. Lavoie, C. Michel, and M. Vancoppenolle (2011). Development and validation of a onedimensional snow-ice algae model against observations in Resolute Passage, Canadian Arctic Archipelago. Journal of Geophysical Research, 116, C04010, doi:10.1029/2010JC006119.

Polashenski, C., D. Perovich, and Z. Courville (2012). The mechanisms of sea ice melt pond formation and evolution. Journal of Geophysical Research, 117, C01001, doi:10.1029/2011JC007231.

Popova, E. E., A. Yool, A. C. Coward, F. Dupont, C. Deal, S. Elliott, E. Hunke, M. Jin, M. Steele, and J. Zhang (2012). What controls primary production in the Arctic Ocean? Results from an intercomparison of five general circulation models with biogeochemistry. Journal of Geophysical Research, 117, C00D12, doi:10.1029/2011JC007112.

Popova, E., E., A. Yool, A. C. Coward, Y. K. Aksenov, S. G. Alderson, B. A. de Cuevas, and T. R. Anderson (2010). Control of primary production in the Arctic by nutrients and light: insights from a high resolution ocean general circulation model. Biogeosciences, 7, 3569-3591.

Poulin, M., Daugbjerg, N., Gradinger, R., Ilyash, L., Ratkova, T., and C. von Quillfeldt, C. (2011). Pan-Arctic biodiversity of marine pelagic and sea-ice unicellular eukaryotes: a firstattempt assessment. Marine Biodiversity, 41, 13-28.

Prentice, I. C., Farquhar, G. D., Fasham, M. J. R., Goulden, M. L., Heimann, M. and co-authors (2001). The carbon cycle and atmospheric CO2. In: Climate change: the scientificbasis, the contribution of WGI of the IPCC to the IPCC Third Assessment Report (TAR), (eds. J. T. Houghton and D. Yihui). Cambridge University Press, Cambridge, UK, 183-237.

Priscu, J. C., M. T. Downes, L. R. Priscu, A. C. Palmisano, and C. W. Sullivan (1990). Dynamics of ammonium oxidizer activity and nitrous oxide (NO) within and beneath Antarctic sea ice. Marine Ecology Progress Series, 62, 37-46.

Raiswell, R., L. G. Benning, M. Tranger and S. Tulaczyk (2008). Bioavailable iron in the Southern Ocean: the significance of the iceberg conveyor belt. Geochemical Transactions, 9:7.

Rampal, P., J. Weiss, and D. Marsan (2009). Positive trend in the mean speed and deformation rate of Arctic sea ice, 1979-2007. Journal of Geophysical Research, 114, C05013, doi:10.1029/2008JC005066.

Randall, K., M. Scarratt, M. Levasseur, S. Michaud, H. Xie, and M. Gosselin (2012). First measurements of nitrous oxide in Arctic sea ice. Journal of Geophysical Research, 117, C00G15, doi:10.1029/2011JC007340.

Rankin, A. M., E. W. Wolff, and S. Martin (2002). Frost flowers: Implications for tropospheric chemistry and ice core interpretation. Journal of Geophysical Research, 107(D23), 4683, doi:10.1029/2002JD002492.

Raymond, B., Meiners, K.M., Fowler, C.W., Pasquer, B., Williams, G.D., Nicol, S. (2009). Cumulative solar irradiance and potential large-scale sea ice algae distribution off east Antarctica $\left(30^{\circ} \mathrm{E}-150^{\circ} \mathrm{E}\right)$. Polar Biology, 32, 443-452.

Raymond, J. A., and Kim, H. J., (2012). Possible role of horizontal gene transfer in the colonization of sea ice by algae. PLoS ONE 7(5): e35968, doi:10.1371/journal.pone.0035968.

Reeburgh, W. S. (1984), Fluxes associated with brine motion in growing sea ice-atmosphere, Polar Biology, 3, 29-33.

Renaud, P. E., Riedel, A., Michel, C., Morata, N., Gosselin, M., Juul-Pedersen, T. and A. Chiuchiolo (2007). Seasonal variations in the benthic community oxygen demand: a response to an ice algal bloom in the Beaufort Sea, Canadian Arctic. Journal of Marine Systems, 67, 1-12.

Riebesell, U., Schloss, I., and V. Smetacek (1991). Aggregation of algae released from melting sea ice: implications for seeding and sedimentation. Polar Biology, 11 (4), 239-248.

Riedel, A., Michel, C., and M. Gosselin (2006). Seasonal study of sea-ice exopolymeric substances (ES) on the Mackenzie shelf: implications for the transport of sea-ice bacteria and algae. Aquatic Microbial Ecology, 45, 195-206.

Riedel, A., Michel, C., Gosselin, M. and B. LeBlanc (2008). Winter-spring dynamics in sea-ice carbon cycling in the coastal Arctic Ocean. Journal of Marine Systems, 74 (3-4), 918-932.

Rösel, A., and L. Kaleschke (2012). Exceptional melt pond occurrence in the years 2007 and 2011 on the Arctic sea ice revealed from MODIS satellite data. Journal of Geophysical Research, 117, C05018, doi:10.1029/2011JC007869.

Rothrock, D. A., D. B. Percival, and M. Wensnahan (2008). The decline in Arctic sea-ice thickness: Separating the spatial, annual, and interannual variability in a quarter century of submarine data. Journal of Geophysical Research, 113, C05003, doi:10.1029/2007JC004252.

Różańska, M., Gosselin, M., Poulin, M., Wiktor, J. M., and C. Michel (2009). Influence of environmental factors on the development of bottom ice protist communities during the winter-spring transition. Marine Ecology Progress Series, 386, 43-59.

Rue, E. L., and K. W. Bruland (1995). Complexation of iron (III) by natural organic ligands in the Central North Pacific as determined by a new competitive ligand equilibration/ adsorptive cathodic stripping voltammetric method. Marine Chemistry, 50, 117-138.

Rysgaard, S., and R. N. Glud (2004). Anaerobic N production in Arctic sea ice. Limnology and Oceanography, 49(1), 86-94.

Rysgaard, S., Bendtsen, J., Delille, B., Dieckmann, G.S., Glud, R.N., Kennedy, H., Mortensen J., Papadimitriou, S., 
Thomas, D. N., and J. L. Tison (2011). Sea ice contribution to the air-sea $\mathrm{CO}$ exchange in the Arctic and Southern Oceans. Tellus B, 63, 823-830.

Rysgaard, S., Glud, R. N., Sejr, M. K., Bendtsen, J., and P. B. Christensen (2007). Inorganic carbon transport during sea ice growth and decay: A carbon pump in polar seas. Journal of Geophysical Research, 112, C03016, doi:10.1029/2006JC003572.

Rysgaard, S., Kühl, M., Glud, R. N., and J. W. Hansen (2001). Biomass, production and horizontal patchiness of sea ice algae in a high-Arctic fjord (Young Sound, NE Greenland). Marine Ecology Progress Series, 223, 15-26.

Sabine, C. L., R. A. Feely, N. Gruber, R. M. Key, K. Lee, J. L. Bullister, R. Wanninkhof, C. Wong, D. W. R. Wallace, B. Tilbrook, F. J. Millero, T.-H. Peng, A. Kozyr, T. Ono, andet A. F. Rios (2004). The Oceanic Sink for Anthropogenic $\mathrm{CO}_{2}$. Science, 305, 367-371.

Saenz, B. T., and K. R. Arrigo (2012). Simulation of a sea ice ecosystem using a hybrid model for slush layer desalination. Journal of Geophysical Research, 117, C05007, doi:10.1029/2011JC007544.

Sakshaug, E. (2004). Primary and secondary production in the Arctic Seas, in The Organic Carbon Cycle in the Arctic Ocean, edited by R. Stein and R. Macdonald, pp. 57-81, Springer, Berlin, doi:10.1007/978-3-642-18912-8_3.

Sarmiento, J. L., and N. Gruber (2006). Ocean Biogeochemical Dynamics, Princeton University Press, 526 pp.

Sarnthein, M., U. Pflaumann, and M. Weinelt (2003). Past extent of sea ice in the northern North Atlantic inferred from foraminiferal paleotemperature estimates. Paleoceanography, 18(2), 1047, doi:10.1029/2002PA000771.

Sejr, M. K., Krause-Jensen, D., Rysgaard, S., Sørensen, L. L., Christensen, P. B. and R. N., Glud, R.N. (2011). Air-sea flux of $\mathrm{CO}$ in Aarctic coastal waters influenced by glacial melt water and sea ice. Tellus $B, 63,815-822$.

Semiletov, I., A. Makshtas, S.-I. Akasofu, and E. L Andreas (2004). Atmospheric CO balance: The role of Arctic sea ice. Geophysical Research Letters, 31, L05121, doi:10.1029/2003GL017996.

Serreze, M. C., and C. M. Hurst (2000). Representation of mean Arctic precipitation from NCEP-NCAR and ERA reanalyses. Journal of Climate, 13, 182-201.

Shakhova, N.E., Sergienko, V.I., Semiletov, I.P. (2009). The contribution of the East Siberian shelf to the modern methane cycle. Herald of the Russian Academy of Sciences 79, 237-246.

Sibert, V., Zakardjian, B., Gosselin, M., Starr, M., Senneville, S., and Y. LeClainche (2011). 3D bio-physical model of the sympagic and planktonic productions in the Hudson Bay system. Journal of Marine Systems, 88, 401-422.
Sigman, D. M., M. P. Hain, and G. H. Haug (2010). The polar ocean and glacial cycles in atmospheric $\mathrm{CO}$ concentration. Nature, 466, 47-55.

Simpson, W. R., L. D. Carlson, G. Hönninger, T. A. Douglas, M. Sturm, D. Perovich, and U. Platt (2007). First-year sea ice contact predicts bromine monoxide $(\mathrm{BrO})$ levels at Barrow, Alaska better than potential frost flower contact. Atmospheric Chemistry and Physics, 7, 621-627, doi:10.5194/acp-7-621- 2007.

Smedsrud, L. H. (2002). A model for entrainment of sediment into sea ice by aggregation between frazil-ice crystals and sediment grains. Journal of Glaciology, 48, 5161.

Smith Jr., W. O. and D. M. Nelson (1986). Importance of Ice Edge Phytoplankton Production in the Southern Ocean. BioScience, 36 (4), 251-257.

Smith Jr., W. O., and D. M. Nelson (1985). Phytoplankton bloom produced by a receding ice edge in the Ross Sea: Spatial coherence with the density field. Science, 227, 163166.

Smith Jr., W. O., and J. C. Comiso (2008). Influence of sea ice on primary production in the Southern Ocean: A satellite perspective. Journal of Geophysical Research, 113, (C05S93), doi:10.1029/2007JC004251.

Smith, R. E. H., Anning, J., Clement, P., and G. Cota (1988). Abundance and production of ice algae in Resolute Passage, Canadian Arctic. Marine Ecology Progress Series, 48, 251-263.

Søreide, J.E., Leu, E., Berge, J., Graeve, M., and S. FalkPetersen (2010). Timing of blooms, algal food quality and Calanus glacialis reproduction and growth in a changing Arctic. Global Change Biology, 16, 3154-3163.

Stammerjohn, S. E., D. G. Martinson, R. C. Smith and R. A. lannuzzi (2008). Sea ice in the western Antarctic Peninsula region: Spatio-temporal variability from ecological and climate change perspectives. Deep-Sea Research II, 55 (1819), 2041-2058.

Stammerjohn, S., R. Massom, D. Rind, and D. Martinson, (2012). Regions of rapid sea ice change: An interhemispheric seasonal comparison. Geophysical Research Letters, 39, L06501, doi:10.1029/2012GL050874.

Steele, M. (1992). Sea ice melting and floe geometry in a simple ice-ocean model. Journal of Geophysical Research, $97,17,729-17,738$.

Stefels, J. (2000). Physiological aspects of the production and conversion of DMSP in marine algae and higher plants. Journal of Sea Research, 43, 183-197

Stefels, J., G. Carnat, J.W.H. Dacey, T. Goossens, J.T.M. Elzenga, and J.-L. Tison (2012). The analysis of dimethylsulfide and dimethylsulfoniopropionate in sea ice: dry-crushing and melting using stable isotope additions. Marine Chemistry, 128-129, 34-43, doi: 10.1016/j.marchem.2011.09.007. 
Stefels, J., M. Steinke, S. Turner, G. Malin, and S. Belviso (2007). Environmental constraints on the production and removal of the climatically active gas dimethylsulphide (DMS) and implications for ecosystem modeling. Biogeochemistry, 83, 245-275, doi:10.1007/s10533-0079091-5.

Steinacher, M., F. Joos, T. L. Frölicher, L. Bopp, P. Cadule, V. Cocco, S. C. Doney, M. Gehlen, K. Lindsay, J. K. Moore, B. Schneider, and J. Segschneider (2010). Projected 21st century decrease in marine productivity : a multi-model analysis. Biogeosciences, 7, 979-1005.

Stephens, B. B., and R. F. Keeling (2000). The influence of Antarctic sea ice on glacial-interglacial $\mathrm{CO}$ variations. Nature, 404, 171-174.

Sturm, M. and R.A. Massom (2010). Snow and sea ice. In: Sea Ice, Second Edition (eds D. N. Thomas and G. S. Dieckmann), pp. 153-204, Wiley-Blackwell, Oxford, UK.

Style, R. W., and M. G. Worster (2009). Frost flower formation on sea ice and lake ice. Geophysical Research Letters, 36, L11501, doi:10.1029/2009GL037304.

Sunda, W., D.J. Kieber, R.P. Kiene, and S. Huntsman (2002). An antioxidant function for DMSP and DMS in marine algae. Nature, 418, 317-320.19

Tagliabue, A., Bopp, L., Dutay, J.-C., Bowie, A. R., Chever, F., Jean-Baptiste, P., Bucciarelli, E., Lannuzel, D., Remenyi, T., Sarthou, G., Aumont, O., Gehlen, M., and C. Jeandel (2010). Hydrothermal contribution to the oceanic dissolved iron inventory. Nature Geoscience, 3, 252-256.

Takahashi, T., Sutherland, S. C, Wanninkhof, R., Sweeney, C., Feely, A., Chipman, D. W., Hales, B. E., Friederich, G. E., Chavez, F., Sabine, C. L., Watson, A.J., Bakker, D. C. E., Schuster, UE., Metzl, N., Yoshikawa-Inoue, H., Ishii, M., Midorikawa, T., Nojiri, Y., Körtzinger, A., Steinhoff, T., Hoppema, M., Olafsson, J., Arnarson, T. S., Tilbrook, B., Johannessen, T., Olsen, A., Bellerby, R., Wong, C.S., Delille, B., Bates, N.R., and H. J. W. de Baar (2009). Climatological mean and decadal change in surface ocean $\mathrm{pCO}_{\text {, and net }}$ sea-air $\mathrm{CO}_{2}$ flux over the global oceans. Deep-Sea Research II, 56, 554-577.

Tedesco, L., M. Vichi, J. Haapala, et T. Stipa (2010). A dynamic Biologically Active Layer for numerical studies of the sea ice ecosystem. Ocean Modelling, 35, 89-104.

Tedesco, L., Vichi, M., and D. N. Thomas (2012). Process studies on the ecological coupling between sea ice algae and phytoplankton. Ecological Modelling, 226, 120-138.

Thomas, D. N., and G. S. Dieckmann (2010). Sea Ice, Second Edition, Wiley-Blackwell, Oxford, UK, 621pp.

Thomas, D. N., Kattner, G., Engbrodt, R., Giannelli, V., Kattner, G., Kennedy, H., Haas, C., and G. S. Dieckmann (2001). Dissolved organic matter in Antarctic sea ice. Annals of Glaciology, 33, 297-303.

Thomas, D.N., Papadimitriou, S., Michel C. (2010). Biogeochemistry of Sea Ice. In: Sea Ice, Second Edition (eds
D. N. Thomas and G. S. Dieckmann), pp. 425-468, WileyBlackwell, Oxford, UK.

Thorndike, A. S., Rothrock, D. A., Maykut, G. A., and Colony, R. (1975). The thickness distribution of sea ice. Journal of Geophysical Research, 80, 4501-4513.

Tison, J.-L., F. Brabant, I. Dumont, and J. Stefels (2010), High-resolution dimethyl sulfide and dimethylsulfoniopropionate time series profiles in decaying summer first-year sea ice at Ice Station Polarstern, western Weddell Sea, Antarctica. Journal of Geophysical Research, 115, G04044, doi:10.1029/2010JG001427.

Tison, J.-L., Haas, C., Gowing, M.M., Sleewaegen, S., Bernard, A. (2002). Tank study of physico-chemical controls on gas content and composition during growth of young sea ice. Journal of Glaciology, 48, 177-1910.

Tison, J.-L., R. D. Lorrain, A. Bouzette, M. Dini, A. Bondesan, and M. Stiévenard (1998). Linking landfast sea ice variability to marine ice accretion at Hells Gate Ice Shelf, Ross Sea. In Antarctic Sea Ice: Physical Processes, Interactions and Variability, Antarctic Research Series, 74, edited by M. O. Jeffries, pp. 375-407, AGU, Washington DC.

Tison, J.-L., Worby, A. P., Delille, B., Brabant, F., Papadimitriou, S., Thomas, D. N., de Jong, J., Lannuzel, D., and C. Haas (2008). Temporal evolution of decaying summer first-year sea ice in the western Weddell Sea, Antarctica, Deep-Sea Research II, 55, 975-987.

Tremblay, J.-E., and J. Gagnon (2009). The effect of irradiance and nutrient supply on the productivity of Arctic waters: A perspective on climate change. In: Influence of Climate Change on the Changing Arctic and Sub-Arctic Conditions, edited by J. C. J. Nihoul and A. G. Kostianoy, Springer, New York, pp. 73-94.

Tremblay, J.-E., Bélanger, S., Barber, D.G., Asplin, M., Martin, J., Darnis, G., Fortier, L., Darnis, G., Gratton, Y., Link, H., Archambault, P., Sallon, A., Michel, C., Williams, W.G., Phillippe, B., and M. Gosselin (2011). Climate forcing multiplies biological productivity in the coastal Arctic Ocean. Geophysical Research Letters, 38, L18604, doi:10.1029/2011GL048825.

Trevena, A. J., and G. B. Jones (2006). Dimethylsulphide and dimethylsulphoniopropionate in Antarctic sea ice and their release during sea ice melting. Marine Chemistry, 98, 210222.

Trevena, A. J., G.B. Jones, S.W. Wright, and R. L. van den Enden (2000). Profiles of DMSP, algal pigments, nutrients and salinity in pack ice from eastern Antarctica. Journal of Sea Research, 43, 265-273.

Trevena, A., and G. Jones (2012). DMS flux over the Antarctic sea ice zone. Marine Chemistry, 134-135, 47-58, doi: 10.1016/j.marchem.2012.03.001.

Trevena, A.J., G.B. Jones, S.W. Wright, and R.L. van den Enden (2003). Profiles of dimethylsulphoniopropionate (DMSP), algal pigments, nutrients and salinity in fast ice of 
Prydz Bay, Antarctica. Journal of Geophysical Research, 108, 3145, doi:10.1029/2002JC0011369.

Tsurikov, V. L. (1979). The formation and composition of the gas content of sea ice. Journal of Glaciology 22, 67-81.

Tuhkuri, J. and Lensu, M. (2002). Laboratory tests on ridging and rafting of ice sheets. Journal of Geophysical Research, 107, 3125, doi:10.1029/2001JC000848.

Turner, S.M., P.D. Nightingale, W. Broadgate, and P.S. Liss (1995). The distribution of dimethyl sulphide and dimethylsulphoniopropionate in Antarctic waters and sea ice, Deep-Sea Research II, 42, 1059-1080.

Underwood G. J. C., Fietz, S., Papadimitriou, S., Thomas, D.N., and G. S. Dieckmann (2010). Distribution and composition of dissolved extracellular polymeric substances (EPS) in Antarctic sea ice. Marine Ecology Progress Series, 404, 1-19.

Untersteiner, N. (1968). Natural desalination and equilibrium salinity profile of perennial sea ice. Journal of Geophysical Research, 73, 1251-1257.

Untersteiner, N.: On the mass and heat budget of arctic sea ice, Arch. Meteorol. Geophys. Bioklimatol., A, 12, 151-182, 1961.

van der Merwe, P., D. Lannuzel, A. R. Bowie, C. A. Mancuso Nichols, and K. M. Meiners (2011a). Iron fractionation in pack and fast ice in East Antarctica: Temporal decoupling between the release of dissolved and particulate iron during spring melt. Deep-Sea Research II, 58, 1222-1236.

van der Merwe, P., Lannuzel, D., Bowie, A. R., and K. M. Meiners (2011b). High temporal resolution observations of spring fast ice melt and seawater iron enrichment in East Antarctica. Journal of Geophysical Research, 116(3).

van der Merwe, P., Lannuzel, D., Mancuso Nichols, C. A., Meiners, K.M., Heil, P., Norman, L., Thomas, D. N., and A. R. Bowie (2009). Biogeochemical observations during the winter-spring transition in East Antarctic sea ice: Evidence of iron and exopolysaccharide controls. Marine Chemistry, 115 (3-4), 163-175.

Vancoppenolle, M., Bouillon, S., Fichefet, T., Goosse, H., Lecomte, O., Morales Maqueda, M.A., and G. Madec (2012). LIM, The Louvain-la-Neuve sea Ice Model, Notes du Pôle de modélisation, No 31, ISSN No 1288-1619, Institut PierreSimon Laplace (IPSL), France.

Vancoppenolle, M., C. M. Bitz, and T. Fichefet (2007). Summer landfast sea ice desalination at Point Barrow, Alaska: Modeling and observations. Journal of Geophysical Research, 112, C04022, doi:10.1029/2006JC003493.

Vancoppenolle, M., H. Goosse, A. de Montety, T. Fichefet, B. Tremblay, et J.-L. Tison (2010). Modeling brine and nutrient dynamics in Antarctic sea ice : the case of dissolved silica. Journal of Geophysical Research, 115 (C2), C02005, doi: 10.1029/2009JC005369.

Vancoppenolle, M., T. Fichefet, and H. Goosse (2009a). Simulating the mass balance and salinity of Arctic and
Antarctic sea ice. 2. Importance of salinity variations. Ocean Modelling, 27, 54-69, doi:10.1016/j.ocemod. 2008.11.003.

Vancoppenolle, M., T. Fichefet, H. Goosse, S. Bouillon, G. Madec and M.A. Morales Maqueda (2009b). Simulating the mass balance and salinity of Arctic and Antarctic sea ice. 1 . Model description and validation. Ocean Modelling, 27, 3353, doi:10.1016/j.ocemod.2008.10.005.

Wagener, T., C. Guieu, R. Losno, S. Bonnet, and N. Mahowald (2008). Revisiting atmospheric dust export to the Southern Hemisphere ocean: Biogeochemical implications, Global Biogeochemical Cycles, 22, GB2006, doi:10.1029/2007GB002984.

Warren, S. G., I. G. Rigor, N. Untersteiner, Radionov, V. F., Bryazgin, N. N., Aleksandrov, Y. I., and R. Colony (1999). Snow depth on Arctic sea ice. Journal of Climate, 12, 18141829.

Warren, S.G., and Wiscombe W.J. (1980). A model for the spectral albedo of snow. II: Snow containing atmospheric aerosols. Journal of Atmospheric Sciences, 37, 2734-2745.

Wassmann, P., Duarte, C. M., Agustí, S. and M. K. Sejr (2011). Footprints of climate change in the Arctic marine ecosystem. Global Change Biology, 17, 1235-1249. doi: 10.1111/j.1365-2486.2010.02311.x.

Watson, A. J., and P. S. Liss (1998). Marine biological controls on climate via the carbon and sulphur geochemical cycles. Philosophical Transactions of the Royal Society of London, Series B, Biological Sciences, 353, 41-50.

Weeks, W. F. (2010). On sea ice, University of Alaska Press, Fairbanks, Alaska, 664 pp.

Weeks, W. F., and S. F. Ackley (1986). The growth, structure, and properties of sea ice, In: The Geophysics of sea ice (ed. N. Untersteiner), vol. 146 of NATO ASI Series. Series B, Physics, pp. 9-164. Plenum, New York.

Wells, A. J., J. S. Wettlaufer, and S. A. Orszag (2011). Brine fluxes from growing sea ice. Geophysical Research Letters, 38, L04501, doi:10.1029/2010GL046288.

Williams, G. D., T. Maksym, J. Wilkinson, C. Kunz, E. Trujillo, A. Steer, P. Kimball, R. Massom, K. M. Meiners, K. Leonard, C. Murphy, P. Heil, J. Lieser, T. Lachlan-Cope and H. Singh (submitted). Beyond point measurements: 3-D characterization of sea ice floes.

Williams, W.J., and Carmack, E.C. (2008). Combined effect of wind-forcing and isobath divergence on upwelling at Cape Bathurst, Beaufort Sea. Journal of Marine Research, 66: 645-663.

WMO (1970). WMO sea-ice nomenclature, terminology, codes and illustrated glossary. World Meteorological Organisation, Geneva, WMO/OMM/BMO 259, TP 145.

Wolff et al. (2006). Southern Ocean sea-ice extent, productivity and iron flux over the past eight glacial cycles. Nature, 440, 491-496. 
Worby, A. P., C. A. Geiger, M. J. Paget, M. L. Van Woert, S. F. Ackley, and T. L. DeLiberty (2008). Thickness distribution of Antarctic sea ice. Journal of Geophysical Research, 113, C05S92, doi:10.1029/2007JC004254

Worby, A. P., M. O. Jeffries, W. F. Weeks, K. Morris, and R. Jaña (1996). The thickness distribution of sea ice and snow cover during late winter in the Bellingshausen and Amundsen Seas, Antarctica. Journal of Geophysical Research, 101(C12), 28,441-28,455, doi:10.1029/96JC02737.

Yager, P. L., D. W. R. Wallace, K. M. Johnson, W. O. Smith Jr., P. J. Minnett, and J. W. Deming (1995), The Northeast Water Polynya as an atmospheric $\mathrm{CO}$ sink: A seasonal rectification hypothesis. Journal of Geophysical Research, 100(C3), 4389-4398, doi:10.1029/94JC01962.

Yang, X., Pyle, J. A., and R. A. Cox (2008). Sea salt aerosol production and bromine release: Rrole of snow on sea ice. Geophysical Research. Letters, 35, L16815. doi:10.1029/2008GL034536.
Zemmelink, H.J., J.W.H. Dacey, L. Houghton, E.J. Hintsa, and P.S. Liss (2008). Dimethylsulfide emissions over the multi-year ice of the western Weddell Sea. Geophysical Research Letters, 35, L06603, doi: 10.1029/2007GL031847

Zhang, J., Y. H. Spitz, M. Steele, C. Ashjian, R. Campbell, L. Berline, et P. Matrai (2010). Modeling the impact of declining sea ice on the Arctic marine planktonic ecosystem. Journal of Geophysical Research, 115, C10015, doi: 10.1029/2009JC005387.

Zhou J, Delille B, Geilfus N-X, Brabant F, Eicken H, Carnat G, Vancoppenolle M, Tison J-L (in revision). Physical and biogeochemical properties in landfast sea ice (Barrow, Alaska): insights for brine and gas dynamics. Journal of Geophysical Research. 


\section{Tables and Figures}

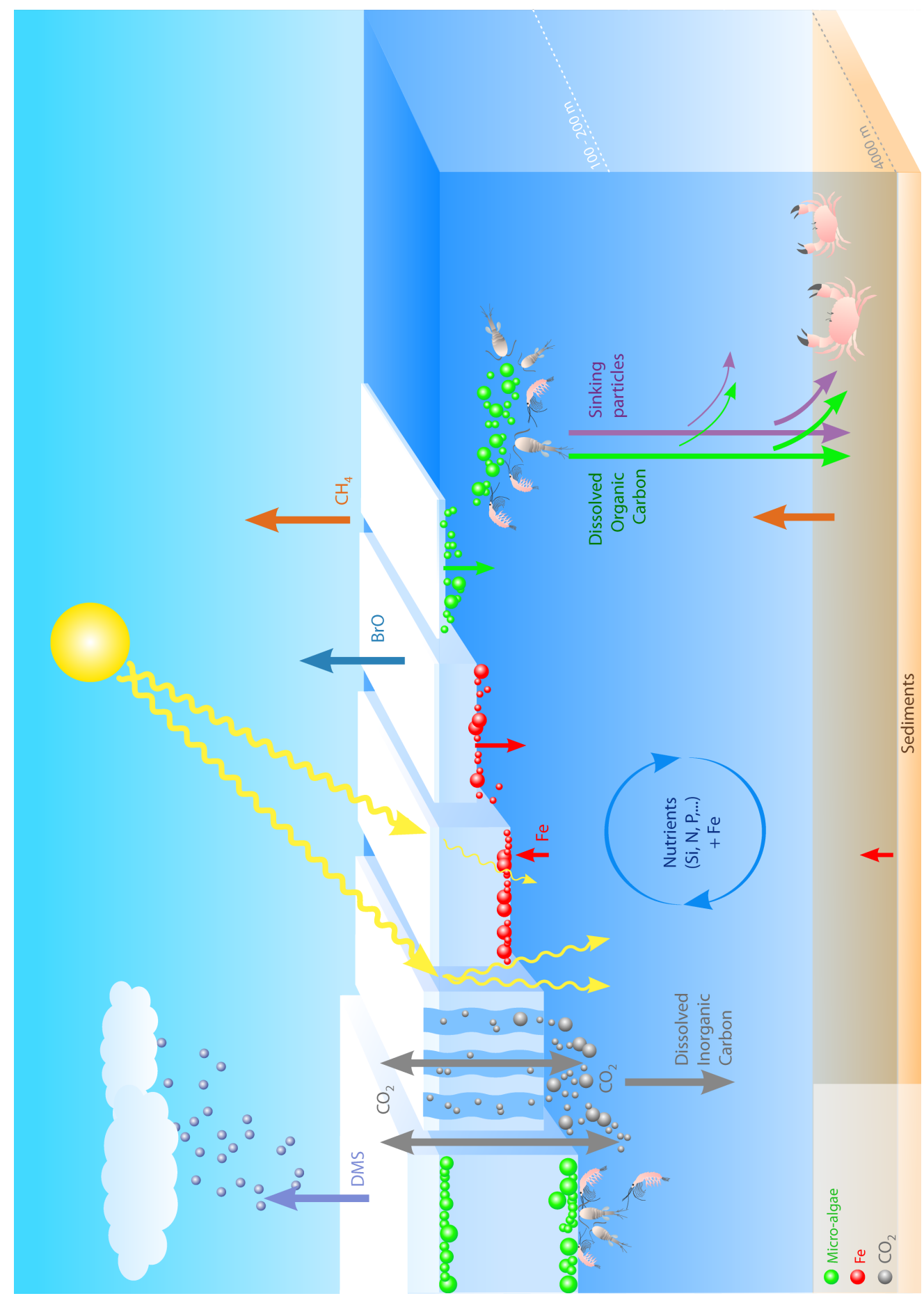

Figure 1. Schematics of the biogeochemical processes occurring in the Polar oceans (see text for details). 


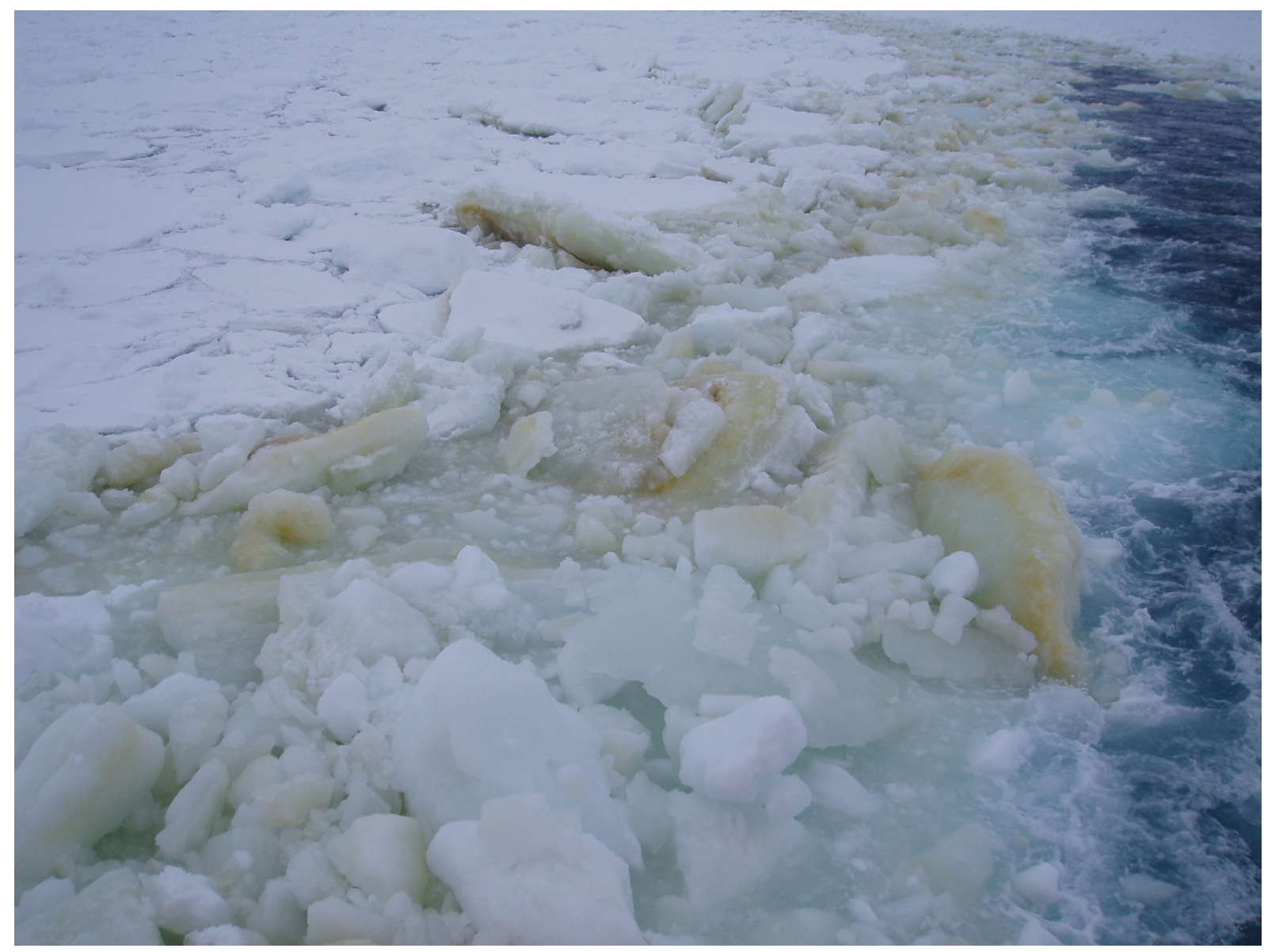

Figure 2. Microbial communities within sea ice, as shown by the brown-green coloration of tilted sea ice floes in the wake of R/N N.B. Palmer, SIMBA cruise, Bellingshausen Sea, Antarctica, October 2007. 

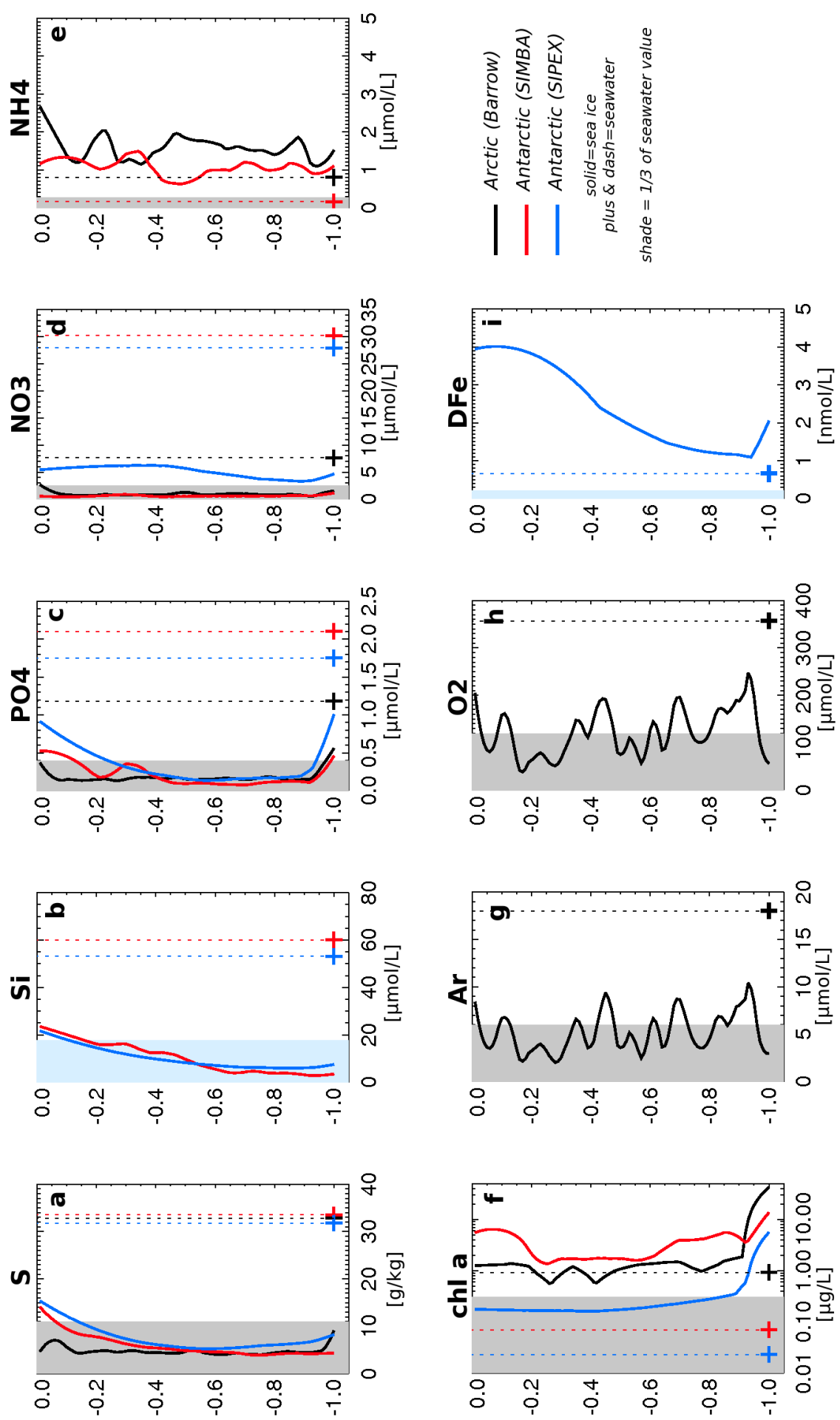

Figure 3. Normalized vertical profiles of bulk concentrations (lines) of biogeochemical tracers in sea ice, along with corresponding seawater concentrations (symbols), observed for typical spring conditions in the Arctic (black) and the Southern (colors) Oceans. Vertical axes refer to normalized depth. Tracers are: a- salinity (S), b- dissolved silica (Si), c-phosphate $\left(\mathrm{PO}_{4}\right), \mathbf{d}$ - 
nitrate $\left(\mathrm{NO}_{3}\right)$, e- ammonium $\left(\mathrm{NH}_{4}\right)$, f- chl a, g- argon $(\mathrm{Ar})$, $\mathbf{h}$ - oxygen $\left(\mathrm{O}_{2}\right)$ and i- dissolved iron (DFe). Arctic data are from the Belgian IPY ice camp at Point Barrow, stations 7-8, April-May 2009 [Zhou et al., submitted]. Antarctic data come from (i) the SIMBA drift station, Brussels site (5 stations), October 2007, Bellingshausen Sea [see Lewis et al., 2011; for a description of stations]; (ii) the SIPEX expedition (8 stations), September-October 2007, East Antarctic sector of the Southern Ocean [Meiners et al., 2011; van der Merwe et al., 2011a]. Vertical dotted lines extend the seawater concentrations. For indication, full rectangles indicating $1 / 3$ of the seawater concentration data were added (grey, Barrow; light blue, SIPEX). Missing profiles mean that no data were available. 


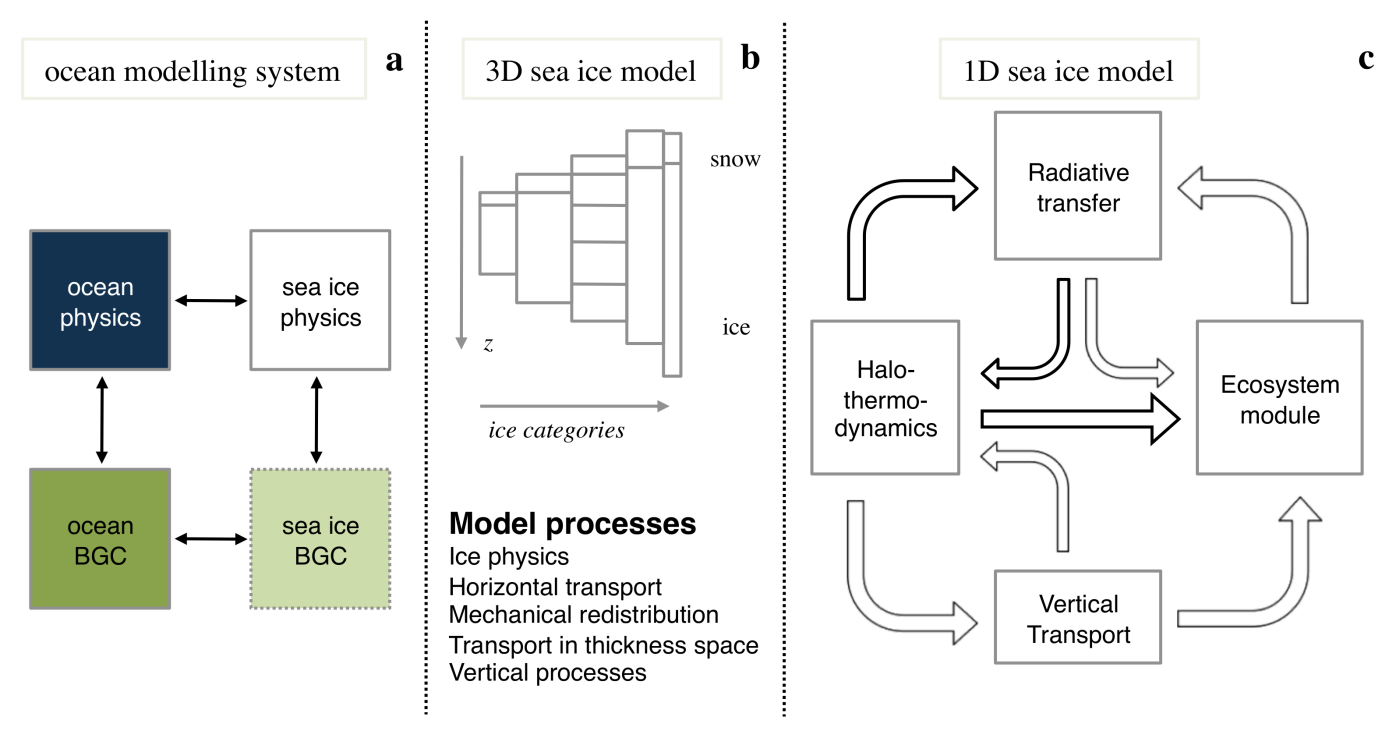

Figure 4. Organigram of (a) a standard ocean modelling system; (b) a typical three-dimensional sea ice model; (c) a one-dimensional sea ice model with an ecosystem component. 
Table 1. Selected properties of Arctic versus Antarctic sea ice (adapted from Dieckmann and Hellmer, 2010).

\begin{tabular}{|c|c|c|}
\hline & Arctic & Antarctic \\
\hline Latitudinal limits & $90^{\circ} \mathrm{N}-60^{\circ} \mathrm{N}^{1}$ & $55^{\circ} \mathrm{S}-75^{\circ} \mathrm{S}$ \\
\hline Average maximum extent ${ }^{2}$ & $15.2 \times 10^{6} \mathrm{~km}^{2}$ & $18.3 \times 10^{6} \mathrm{~km}^{2}$ \\
\hline Average minimum extent ${ }^{2}$ & $6.8 \times 10^{6} \mathrm{~km}^{2}$ & $3.0 \times 10^{6} \mathrm{~km}^{2}$ \\
\hline Trend, annual mean extent ${ }^{2}$ & $-3.8 \%$ per decade & $+1.2 \%$ per decade \\
\hline $\begin{array}{l}\text { Seasonal ice extent (\% of } \\
\max )^{2}\end{array}$ & $8.4 \times 10^{6} \mathrm{~km}^{2}(<60 \%)$ & $15.3 \times 10^{6} \mathrm{~km}^{2}(>80 \%)$ \\
\hline Sea ice residence time & $<1-7$ years & $<1-2$ years \\
\hline Mean ice thickness ${ }^{3}$ & $\begin{array}{l}3.4 m(1980)-2.3 m \\
(2000)\end{array}$ & $0.87 \pm 0.91 \mathrm{~m}$ \\
\hline $\begin{array}{l}\text { Observed trend in ice } \\
\text { thickness }\end{array}$ & Decreasing & No available data \\
\hline Annual snowfall ${ }^{4}$ & $150-400 \mathrm{~mm}$ & $>1000 \mathrm{~mm}$ \\
\hline Annual mean snow depth ${ }^{5}$ & $23 \mathrm{~cm}$ & $16 \pm 20 \mathrm{~cm}$ \\
\hline Flooding \& snow ice & Rare & Extensive \\
\hline Surface melt \& melt ponds & Extensive & Rare \\
\hline Ice textural type & Mainly columnar & $\begin{array}{l}\text { Columnar and (orbicular) } \\
\text { granular }\end{array}$ \\
\hline Maximum algal biomass ${ }^{6}$ & Lower & Higher \\
\hline Location of algal biomass $^{7}$ & Primarily bottom & $\begin{array}{l}\text { Bottom, internal and } \\
\text { surface }\end{array}$ \\
\hline Riverine influence & High & None \\
\hline Sediment-laden sea ice & Frequent & Rare \\
\hline Aeolian influence & High & Low \\
\hline
\end{tabular}

${ }^{1}$ With excursions up to $40^{\circ} \mathrm{N}$ in localized regions (e.g., Sea of Okhotsk).

${ }^{2}$ Satellite passive-microwave estimates from Comiso [2010], covering 1979-2008.

${ }^{3}$ See Rothrock et al. [2008] for the Arctic; Worby et al. [2008] for the Antarctic (1981-2005).

${ }^{4}$ See Serreze and Hurst [2000] for the Arctic; Massom et al. [2001] for the Antarctic.

${ }^{5}$ See Warren et al [1999] for the Arctic; Worby et al. [2008] for the Antarctic.

${ }^{6}$ See Arrigo et al. [2010].

${ }^{7}$ See Gradinger [2009] for the Arctic; Meiners et al. [submitted] for the Antarctic. 
Table 2. Summary of modelling studies involving sea ice biogeochemical processes (extended from Loose et al., 2011).

\begin{tabular}{|c|c|c|c|c|c|c|c|}
\hline & $\begin{array}{l}\text { Location } \\
\text { (period) }\end{array}$ & Ice physics & $\begin{array}{c}\text { Eco- } \\
\text { Dynamics, } \\
\text { algal groups } \\
\text { (limiting } \\
\text { nutrients) }\end{array}$ & $\begin{array}{l}\text { Vertical } \\
\text { grid for } \\
\text { eco- } \\
\text { dynami } \\
\text { cs }\end{array}$ & $\begin{array}{c}\text { Optic } \\
\text { s }\end{array}$ & $\begin{array}{l}\text { Nutrient } \\
\text { fluxes }\end{array}$ & Ocean \\
\hline $\begin{array}{l}\text { Arrigo et al. } \\
(1993)\end{array}$ & $\begin{array}{l}\text { Antarctic } \\
\text { fast ice } \\
\text { (Sep-Jan) }\end{array}$ & 1D Semtner ${ }^{1}$ OL & $\begin{array}{l}\text { N-P Redfield, } \\
1 \text { group (N, Si, } \\
P)\end{array}$ & $\begin{array}{l}\text { Multi- } \\
\text { layer }\end{array}$ & $\begin{array}{l}\mathrm{N}- \\
\text { band } \\
\text { (no } \\
\text { snow) }\end{array}$ & Diffusion & n.a. \\
\hline $\begin{array}{l}\text { Arrigo et al. } \\
(1997)\end{array}$ & $\begin{array}{l}\text { Southern } \\
\text { Ocean } \\
\text { (Oct 89- } \\
\text { Apr 98) }\end{array}$ & $\begin{array}{l}\text { 3D Satellite } \\
\text { concentration + } \\
\text { Semtner }{ }^{1} \text { OL }\end{array}$ & $\begin{array}{l}\text { N-P Redfield, } \\
1 \text { group (N, Si, } \\
P)\end{array}$ & $\begin{array}{l}\text { Box }^{2} \\
\text { (surface) }\end{array}$ & $\begin{array}{l}\mathrm{N}- \\
\text { band } \\
\text { (no } \\
\text { snow) }\end{array}$ & Diffusion & n.a. \\
\hline $\begin{array}{l}\text { Lavoie et al. } \\
(2005)\end{array}$ & $\begin{array}{l}\text { Canadian } \\
\text { Arctic } \\
\text { (May-July } \\
\text { 02) }\end{array}$ & 1D Semtner ${ }^{1} 3 \mathrm{~L}$ & $\begin{array}{l}\text { N-P Redfield, } \\
1 \text { group (Si) }\end{array}$ & $\begin{array}{l}\text { Box }^{2} \\
\text { (bottom) }\end{array}$ & $\begin{array}{l}1- \\
\text { band }\end{array}$ & Diffusion & n.a. \\
\hline $\begin{array}{l}\text { Jin et al. } \\
(2006)\end{array}$ & $\begin{array}{l}\text { Barrow, } \\
\text { Arctic } \\
\text { (Apr-Jun } \\
\text { 02) }\end{array}$ & $\begin{array}{l}\text { Ice physical } \\
\text { observations }\end{array}$ & $\begin{array}{l}\mathrm{N}-\mathrm{P} \text { Redfield, } \\
1 \text { group }\left(\mathrm{NO}_{3},\right. \\
\left.\mathrm{NH}_{4}, \mathrm{Si}\right)\end{array}$ & $\begin{array}{l}\text { Box }^{2} \\
\text { (bottom) }\end{array}$ & $\begin{array}{l}1- \\
\text { band }\end{array}$ & $\begin{array}{l}\text { Diffusion + ad- } \\
\text { hoc summer } \\
\text { enhancement }\end{array}$ & n.a. \\
\hline $\begin{array}{l}\text { Tedesco et al. } \\
(2010)\end{array}$ & $\begin{array}{l}\text { Arctic } \\
\text { (Sep 05- } \\
\text { Apr 06); } \\
\text { Baltic (Dec } \\
00 \text { - Mar } \\
01 \text { ) }\end{array}$ & $\begin{array}{l}\text { 1D Semtner }{ }^{1} \mathrm{OL} \\
+ \text { snow }\end{array}$ & $\begin{array}{l}2 \text { groups, } \\
\text { varying } \mathrm{C}, \mathrm{N}, \\
\mathrm{P}, \mathrm{Si}, \mathrm{Chl} \text { cell } \\
\text { quotas }\end{array}$ & $\begin{array}{l}\mathrm{Box}^{2} \\
\text { (BAL) }\end{array}$ & $\begin{array}{l}1- \\
\text { band }\end{array}$ & $\begin{array}{l}\text { Growth and } \\
\text { melt }\end{array}$ & n.a. \\
\hline $\begin{array}{l}\text { Vancoppenoll } \\
\text { e et al. (2010) }\end{array}$ & $\begin{array}{l}\text { Weddell } \\
\text { Sea (Feb- } \\
\text { Dec 04) }\end{array}$ & $\begin{array}{l}\text { 1D Multi-layer } \\
\text { energy } \\
\text { conserving + } \\
\text { brine physics }\end{array}$ & $\begin{array}{l}\text { Prescribed } \\
\text { production, } 1 \\
\text { nutrient (Si) }\end{array}$ & $\begin{array}{l}\text { Multi- } \\
\text { layer }\end{array}$ & $\begin{array}{l}1- \\
\text { band }\end{array}$ & $\begin{array}{l}\text { Brine } \\
\text { transport }+ \\
\text { growth and } \\
\text { melt }\end{array}$ & n.a. \\
\hline $\begin{array}{l}\text { Pogson et al. } \\
(2011)\end{array}$ & $\begin{array}{l}\text { Canadian } \\
\text { Arctic } \\
\text { (May-July } \\
\text { 02) }\end{array}$ & $\begin{array}{l}\text { 1D Multi-layer } \\
\text { energy } \\
\text { conserving }\end{array}$ & $\begin{array}{l}\mathrm{N}-\mathrm{P}, 1 \text { group } \\
\text { (Si) }\end{array}$ & $\begin{array}{l}\text { Box }^{2} \\
\text { (bottom) }\end{array}$ & $\begin{array}{l}1- \\
\text { band }\end{array}$ & Diffusion & n.a. \\
\hline $\begin{array}{l}\text { Lavoie et al. } \\
(2009)\end{array}$ & $\begin{array}{l}\text { Canadian } \\
\text { Arctic } \\
\text { (Jan-Dec } \\
87 \text { ) }\end{array}$ & 1D Semtner ${ }^{1}$ 3L & $\begin{array}{l}\text { N-P Redfield, } \\
1 \text { group (Si) }\end{array}$ & $\begin{array}{l}\text { Box }^{2} \\
\text { (bottom) }\end{array}$ & $\begin{array}{l}1- \\
\text { band }\end{array}$ & Diffusion & $\begin{array}{l}\text { 1D } \\
\text { physic } \\
\text { s and } \\
\text { BGC }\end{array}$ \\
\hline $\begin{array}{l}\text { Sibert et al. } \\
(2011)\end{array}$ & $\begin{array}{l}\text { Hudson } \\
\text { Bay (Jan- } \\
\text { Dec 03) }\end{array}$ & $\begin{array}{l}\text { 3D Transport, } \\
\text { Semtner }^{1} 3 \mathrm{~L}\end{array}$ & $\begin{array}{l}\mathrm{N}-\mathrm{P}-\mathrm{Z}, 1 \\
\text { group }(\mathrm{N})\end{array}$ & $\begin{array}{l}\text { Box }^{2} \\
\text { (bottom) }\end{array}$ & $\begin{array}{l}1- \\
\text { band }\end{array}$ & Turbulent flux & $\begin{array}{l}\text { 3D } \\
\text { physic } \\
\text { s and } \\
\text { BGC }\end{array}$ \\
\hline $\begin{array}{l}\text { Jin et al. } \\
(2011)\end{array}$ & $\begin{array}{l}\text { Arctic } \\
\text { Ocean } \\
(92-07)\end{array}$ & $\begin{array}{l}\text { 3D transport, } \\
\text { ITD }^{3} \text {, multi-layer } \\
\text { energy } \\
\text { conserving }\end{array}$ & $\begin{array}{l}\mathrm{N}-\mathrm{P}\left(\mathrm{NO}_{3},\right. \\
\left.\mathrm{NH}_{4}, \mathrm{Si}\right)\end{array}$ & $\begin{array}{l}\text { Box }^{2} \\
\text { (bottom) }\end{array}$ & $\begin{array}{l}1- \\
\text { band }\end{array}$ & $\begin{array}{l}\text { Diffusion + ad- } \\
\text { hoc summer } \\
\text { enhancement }\end{array}$ & $\begin{array}{l}\text { 3D } \\
\text { physic } \\
s \text { and } \\
\text { BGC }\end{array}$ \\
\hline $\begin{array}{l}\text { Saenz and } \\
\text { Arrigo (2012) }\end{array}$ & $\begin{array}{l}\text { Weddell } \\
\text { Sea (Mar- } \\
\text { May 92) }\end{array}$ & $\begin{array}{l}\text { 1D Multi-layer } \\
\text { energy } \\
\text { conserving + } \\
\text { slush layer }\end{array}$ & $\begin{array}{l}\mathrm{N}-\mathrm{P}, 1 \text { group } \\
\left(\mathrm{NO}_{3}, \mathrm{NH}_{4}, \mathrm{Si}\right. \\
\left.\mathrm{PO}_{4}\right)\end{array}$ & $\begin{array}{l}\text { Multi- } \\
\text { layer }\end{array}$ & $\begin{array}{l}\mathrm{N}- \\
\text { band }\end{array}$ & $\begin{array}{l}\text { Desalination- } \\
\text { based }\end{array}$ & n.a. \\
\hline $\begin{array}{l}\text { Deal et al. } \\
\text { (2011) }\end{array}$ & $\begin{array}{l}\text { Arctic } \\
\text { Ocean (92) }\end{array}$ & $\begin{array}{l}\text { 3D transport, } \\
\text { ITD }^{3} \text {, multi-layer } \\
\text { energy } \\
\text { conserving }\end{array}$ & $\begin{array}{l}\mathrm{N}-\mathrm{P}\left(\mathrm{NO}_{3},\right. \\
\left.\mathrm{NH}_{4}, \mathrm{Si}\right)\end{array}$ & $\begin{array}{l}\text { Box }^{2} \\
\text { (bottom) }\end{array}$ & $\begin{array}{l}1- \\
\text { band }\end{array}$ & $\begin{array}{l}\text { Diffusion + ad- } \\
\text { hoc summer } \\
\text { enhancement }\end{array}$ & $\begin{array}{l}\text { 3D } \\
\text { physic } \\
\text { s and } \\
\text { BGC }\end{array}$ \\
\hline $\begin{array}{l}\text { Tedesco et al. } \\
\text { (2012) }\end{array}$ & $\begin{array}{l}\text { Greenland } \\
\text { fast ice } \\
\text { (Sep 05- } \\
\text { Apr 06) }\end{array}$ & $\begin{array}{l}\text { 1D Semtner }{ }^{1} \mathrm{OL} \\
+ \text { snow }\end{array}$ & $\begin{array}{l}2 \text { groups, } \\
\text { varying } \mathrm{C}, \mathrm{N}, \\
\mathrm{P}, \mathrm{Si}, \mathrm{Chl} \text { cell } \\
\text { quotas }\end{array}$ & $\begin{array}{l}\mathrm{Box}^{2} \\
(\mathrm{BAL})\end{array}$ & $\begin{array}{l}1- \\
\text { band }\end{array}$ & $\begin{array}{l}\text { Growth and } \\
\text { melt }\end{array}$ & $\begin{array}{l}\text { 1D } \\
\text { physic } \\
\text { s and } \\
\text { BGC }\end{array}$ \\
\hline
\end{tabular}

${ }^{1}$ see Semtner [1976], for more details on the zero- (OL) and three-layer (3L) versions of his thermodynamic sea ice model. 
${ }^{2}$ Box models prescribe the location of communities, either at the surface, at the base, or in the so-called Biologically-Active-Layer (BAL) a variable-thickness layer following the $5 \%$ brine volume fraction contour.

${ }^{3}$ ITD = Ice Thickness Distribution 